\title{
O COMPORTAMENTO DAS EXPORTAÇÕES BRASILEIRAS E A DINÂMICA DO COMPLEXO AGROINDUSTRIAL
}

\section{Fátima Marilia Andrade de Carvalho}

Engenheiro Agrônomo

Orientador: Prof. Dr. Guilherme Leite da Silva Dias

Tese apresentada à Escola Superior de Agricultura "Luiz de Queiroz", da Universidade de São Paulo, para obtenção do título de Doutora em agronomia, Área de Concentração: Economia Agrária. 


\section{CATALOGAÇÃO DA PUBLICAÇÃO DIVISÃO DE BIBLIOTECA E DOCUMENTAÇÃO - CAMPUS LUIZ DE QUEIROZ I USP}

Carvalho, Fátima Marília Andrade de

O comportamento das exportações brasileiras e a dinâmica do complexo agroindustrial. Piracicaba, 1995.

$126 \mathrm{P}$.

Tese - ESALQ

Bibliografia.

1. Exportação agrícola - Brasil 2. Indústria agrícola - Brasil

3. Produto agrícola - Exportação I. Escola Superior de Agricultura Luiz de Queiroz, Piracicaba

CDD 338.14

630.209 


\title{
O COMPORTAMENTO DAS EXPORTAÇÕES BRASILEIRAS E A DINÂMICA DO COMPLEXO AGROINDUSTRIAL
}

\author{
FÁTIMA MARÍLIA ANDRADE DE CARVALHO
}

Aprovada em: 09.10.1995

Comissão julgadora:

Prof. Dr. Guilherme Leite da Silva Dias

FEA/ USP

Prof. Dr. Paulo Fernando Cidade de Araújo ESALQ/ USP

Prof. Dr. Joaquim Bento de Souza Ferreira Filho ESALQ/ USP

Prof. Dr. Antônio de Carvalho Campos DER/ UFV

Prof. Dr. Simão Silber 
Aos meus filhos Noelle e Paulo Henrique.

Eles sabem o porquê. 


\section{AGRADECIMENTOS}

É impossivel produzir um trabalho cientifico sem uma orientação firme e segura, sem um envolvimento profundo com o tema e sem a ajuda de amigos. Assim gostaria de deixar registrada aqui minha enorme gratidão, pelas contribuições que recebi, algumas certamente imprescindiveis.

Ao Departamento de Economia Rural da UFV, pelo apoio fundamental em todas as fases, especialmente na elaboração da tese.

Ao Departamento de Economia da ESALQ/USP, com o qual contrai um débito de gratidão por tudo que aprendi.

À CAPES, pelo importante apoio financeiro.

Ao Prof. Guilherme Leite da Silva Dias, pela inteligente orientação e pelo tempo que pôde me dispensar entre tantas outras atividades.

Ao Prof. Paulo Femando Cidade de Araújo, membro da banca examinadora professor e amigo, um agradecimento especial pela amizade que me demonstrou desde que cheguei em Piracicaba.

Aos demais membros da banca examinadora, Prof. Antônio de Carvalho Campos, Prof. Joaquim Bento e Prof. Simão Silber, pelas valiosas e construtivas sugestões.

Ao Dr. Mauro de Resende Lopes, pelas brilhantes idéias e pelo pronto atendimento, sempre que o procurei.

Ao Prof. Fernando Rocha, amigo incomparável, grande incentivador em todos os momentos.

Ao Marcos Jank, um amigo que não me deixou desistir, uma ajuda fundamental. 
Ao meu colega Armando, que de forma muito prestativa, me ajudou a resolver dúvidas surgidas em diferentes fases.

Aos amigos Zé Mário, Nilton e Joquinha, pela competente atuação, sem a qual o trabalho de processamento dos dados teria sido impossivel. Agradeço, ainda, o apoio de Brilhante e Paulo Rigueira nesta fase.

Aos meus colegas de curso, pelas interessantes e sempre proveitosas discussões e pelos bons momentos que passamos juntos. Obrigada, especialmente a Ângela e Ana;

À minha familia, um agradecimento especial, pela maneira consciente e constante que me apoiaram.

À Dadinha, Lúcia e Lilian, pela ajuda fundamental na solução dos diferentes problemas do cotidiano.

Finalmente, aos meus filhos, Noelle e Paulo Henrique, a quem dedico esse trabalho, as minhas desculpas pelo tempo que não pude lhes dedicar e que nunca me foi cobrado.

À ajuda anônima que certamente recebi. 


\section{SUMÁRIO}

Página

LISTA DE TABELAS …............................................................................. vii

LISTA DE FIGURAS ........................................................................................... ix

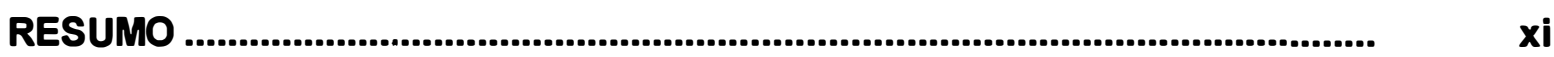

SUMMARY .................................................................................................. xiii

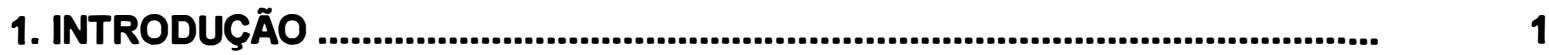

2. EVOLUÇÃO DA ESTRUTURA DA PAUTA DE EXPORTAÇÕES DA AGROINDÚSTRIA BRASILEIRA ............................................................... 9

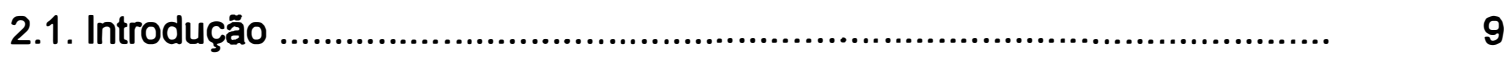

2.2. Tendência gerais da pauta de exportações ................................................ 11

2.3. Tendências das exportações por agregado de produto: básicos, semimanufaturados e manufaturados

3. EVOLUÇÃO DA ESTRUTURA DA PAUTA DO SETOR AGROEXPORTADOR NO MERCADO INTERNACIONAL

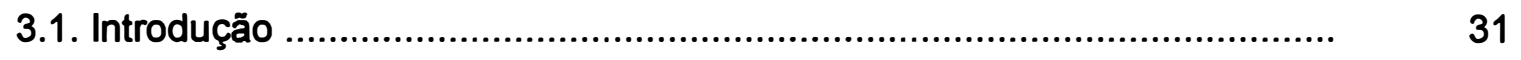

3.2. Tendências das exportações por agregados básicos, semimanafuturados e manufaturados.

3.3. Tendências das exportações por agrupamentos de produtos

4. FONTES DE CRESCIMENTO DAS EXPORTAÇÕES DA AGROINDÚSTRIA BRASILERIA

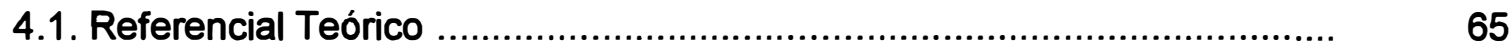

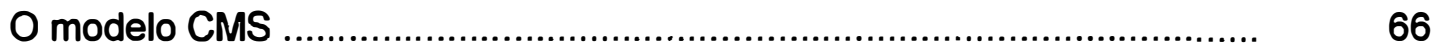

O efeito competitividade ...............................................................

Escolha dos padrões de análise ................................................... 
Página

Indicados de Vantagem Comparativa Revelada

4.2. Análise dos resultados

5. CONCLUSÕES

APÊNDICE 1 : Classificação dos produtos da agroindústria brasileira por agregado

APÊNDICE 2 : Relação dos complexos agroindustriais brasilerias exportados ...

APÊNDICE 3 : Série de dados das exportações da agroindústria brasileira dos produtos básicos, semimanufaturados e manufaturados

APÊNDICE 4 : Taxas geométricas médias de crescimento das exportações da agroindústria brasileira, por produto

APÊNDICE 5 : Relação das regiões, dos blocos econômicos e dos paises considerados na análise

APÊNDICE 6 : Relação dos complexos agroindustriais exportados no mundo dos agrupamentos de produtos

APÊNDICE 7 : Exportações e importações totais brasileiras e saldo da balança comercial 


\section{LISTA DE TABELAS}

Tabela n.

Página

1 Exportações totais da agroindústria brasileira por agregado em valor (1000 US\$ FOB de 1992) e quantidade (ton.), periodo 1973 a 1992 (média movel de 3 anos)

2 Taxa geométrica média de crescimento do valor e da quantidade exportados pela agroindústria brasileira. Periodo 1971-92

3 Taxa geométrica média anual de crescimento das exportações brasileiras por agregado de produtos, em \%

4 Participação percentual das exportações brasileiras por agregado nas exportações brasileiras totais da agroindústria, em $\%$

5 Exportações mundiais de produtos básicos, semimanufaturados em manufaturados, em 1000 US\$FOB de 1992 e participação percentual de cada agregado nototal exportado pela agroindústria

6 Exportações mundiais de produtos básicos, em 1000 US\$ FOB de 1992 e taxas geométricas de crescimento entre os períodos

7 Exportações mundiais de produtos semimanufaturados, em 1000 US $\$$ FOB de 1992 e taxas geométricas de crescimento entre os periodos

8 Exportações mundiais de produtos manufaturados, em 1000 US\$ FOB de 1992 e taxas geométricas de crescimento entre os períodos 
9 Exportações mundiais de cereais (trigo, milho, arroz, cevada, aveia e centeio), em milhões de US\$ FOB de 1992 e taxas geométricas de crescimento entre os periodos

10 Exportações mundiais de grãos oleaginosos (soja, colza, girassol e algodão), em 1000 US\$ FOB de 1992 e taxas geométricas anuais de crescimento entre os periodos

11 Exportações mundiais de óleos vegetais (soja, girassol, colza, algodão e milho), em 1000 US\$ FOB de 1992 e taxas geométricas anuais de crescimento entre os períodos

12 Exportações mundiais de farelos e tortas (soja, colza, girassol e algodăo), em 1000 US\$ FOB de 1992 e taxas geométricas anuais de crescimento entre os períodos

13 Taxas de crescimento das exportações agroindustriais brasileiras e mundiais e fontes de crescimento das exportações agroindustriais brasileiras, em \%

14 Taxas de crescimento das exportações agroindustriais brasileiras e mundiais e fontes de crescimento das exportações agroindustriais brasileiras, em \%

15 Indicadores de vantagem comparativa revelada, por produto da agroindústria brasileira

16 Indicadores de vantagem comparativa revelada, por agregado da agroindústria brasileira 


\section{LISTA DE FIGURAS}

Figura n.

Página

1

Exportações totais da agroindústria brasileira, em valor (a) quantidade(b)

Índice de preços externos dos produtos exportados pela groindústria brasileira.

Exportações da agroindústria brasileira de produtos básicos, em valor (a) e quantidade (b)

Exportações da agroindústria brasileira de produtos semimanufaturados, em valor (a) e quantidade (b)

Exportações da agroindústria brasileira de produtos manufaturados, em valor (a) e quantidade (b)

Índice de preços externos dos produtos exportados pela agroindústria brasileira: básicos, semimanufatu-rados e manufaturados

Participação dos produtos básicos, semimanufaturados e manufaturados no valor total exportado pela agroindústria brasileira

Participação dos produtos básicos, semimanufaturados e manufaturados na quantidade total exportada pela agroindústria brasileira .

Produtos básicos - evolução das exportações mundiais das principais regiões exportadoras 
Figura n.

Página

10 Produtos semimanufaturados - evolução das exportações mundiais das principais regiōes exportadoras

11 Produtos manufaturados - evolução das exportações mundiais das principais regiões exportadoras

12 Exportações mundiais de cereais, por principal mercado exportador (a) e por bloco econômico (b)

13 Grãos oleagionosos - evolução das exportações mundiais das principais regiões exportadoras

14 Óleos vegetais - evolução das exportações mundiais das principais regiões exportadoras

15 Farelos e tortas - evolução das exportações mundiais das principais regiōes exportadoras 


\title{
O COMPORTAMENTO DAS EXPORTAÇÕES BRASILEIRAS E A DINÂMICA DO COMPLEXO AGROINDUSTRIAL
}

\author{
Autora: FÁTIMA MARÍLIA ANDRADE DE CARVALHO \\ Orientador: PROF. DR. GUILHERME LEITE DA SILVA DIAS
}

\section{RESUMO}

O setor agrícola brasileiro apresenta, desde o início da década de 80 , um padrão de crescimento bastante diferenciado do que prevaleceu nos anos 70. De um contexto em que as exportações lideravam o processo de crescimento impulsionadas por preços internacionais favoráveis, por incentivos financeiros à produção e por investimentos em inovações tecnológicas, a agricultura passa a crescer, explorando o potencial representado pelo mercado interno.

O processo generalizado de redução do ritmo de crescimento das exportações agroindustriais ocorre, de forma mais acentuada, no grupo dos exportáveis tradicionais. Simultaneamente, vão ocorrendo mudanças na estrutura na pauta de exportações em termos de maior diversificação, passando a liderar "commodities" com maior valor adicionado ou maior grau de industrialização.

O objetivo desse trabalho é analisar o comportamento das exportações agroindustriais brasileiras nas últimas décadas no contexto dessa nova natureza de inserção do Brasil no mercado internacional e os principais fatores que direcionaram o País a esse posicionamento.

O processo de transformação da estrutura da pauta, que é evidenciado nos resultados obtidos, está sendo liderado principalmente pelos produtos farelo de soja, pasta química de madeira, suco de laranja, tecidos, peles 
e couros, dentre outros. Os indicadores de Vantagem Comparativa (VCR) confirmam esses resultados na medida em que apresentam, para esses produtos, valores sempre crescentes.

Apesar de não ser este um fenômeno específico do Brasil, uma vez que vem ocorrendo em outros países, especialmente da América Latina, é muito mais intenso e persistente no mercado agroexportador brasileiro.

A decomposição das fontes de crescimento das exportações, obtida pela aplicação do método de Constant-Market-Share (CMS), mostrou a importância do crescimento do comércio mundial e da competitividade no desempenho das exportações agroindustriais brasileiras em todos os períodos. A contribuição dessas variáveis como fatores explicativos ocorreu, no entanto, em sentidos opostos, resultado associado aos diferentes fenômenos econômicos externos e internos que foram ocorrendo ao longo de cada período analisado.

O maior estímulo ao crescimento do setor agroexportador é resultado direto do dinamismo do comércio internacional e da expansão da capacidade tecnológica. Esta aparece como a altemativa mais viável na consolidação de vantagens comparativas já adquiridas em setores tradicionais, na sua ampliação em setores que sinalizam os espaços potenciais e na exploração de novas vantagens comparativas, em nichos de mais alta tecnologia. 


\title{
THE BRAZILIAN EXPORT BEHAVIOR AND THE DYNAMICS OF THE AGROINDUSTRIAL SECTOR
}

\author{
Author: FÁTIMA MARILIA ANDRADE DE CARVALHO \\ Advisor: PROF. DR. GUILHERME LEITE DA SILVA DIAS
}

\section{SUMMARY}

Since the beginning of the 1980's, the Brazilian agricultural sector has shown a standard of growth different from what prevailed in the 1970's. The exports led the process of growth stimulated by favorable international prices, financial incentives to production and investments in technological innovations. As an outcome, the agricultural sector expanded, taking advantage of the potential opportunities of the domestic market.

The comprehensive reduction in the rhythm of the exports from the agricultural industrial shows up most in the traditional export commodities. Simultaneously, changes have occurred in the configuration of the export list. Greater diversification has been observed. Commodities with greater added value or greater degree of industrialization have been becoming the leaders.

The objective of this research is to analyze the behavior of the exports of the Brazilian agricultural industry during the last few decades, considering the new context of the insertion of Brazil in the intemational market and the main factors that directed the country towards this position. The process of modification of the export list is being led, specially, by soybean meal products, chemical wood paste, orange juice, cloths, skins 
and hides among others. This result is made evident by the Comparative Advantage Measurements (CAM), which for these products, invariably took on increasing values.

Despite the fact that this has not been a specific Brazilian phenomenon, since it is occurring in other countries, especially in Latin America countries, it is much more intensive and persistent in the Brazilian agricultural export market.

The analysis of the sources of the export growth, using the Constant-MarketShare (CMS) method, revealed the importance of world trade growth and competition in the performance of the Brazilian agricultural industry exports in all of the periods dealt with. Their contributions as explanatory variables were confirmed, although the directions were opposite to what have been hypothesized. These may be associated with the different external and internal economic phenomena that were occurring along each period analyzed.

The major growth stimulus in the agricultural export sector resulted directly from the dynamics of international trade and the expansion of technological capacity. Of these two, the second appears to be the most reasonable alternative in the consolidation of comparative advantages already incorporated by the traditional sector, in its application to the sectors which signal potential markets and in the exploration of new comparative advantages in niches of the highest technology. 


\section{INTRODUÇÃO}

A literatura econômica mais recente ${ }^{1}$ apresenta evidências empíricas que comprovam o processo de inversão da tendência do padrão de crescimento que o setor agrícola brasileiro vem experimentando desde a crise econômica que se originou na década de 70 , concretizou-se no início dos anos 80 , com o fim dos fluxos de poupança externa, e desenvolveu-se ao longo dos anos seguintes. A contratendência do crescimento do intercâmbio agrícola dos anos 70 configura-se na perda da dinâmica das exportações desde o início da década de 80 e, mais recentemente, na estagnação do setor exportador com conseqüentes perdas de autosuficiência e capacidade produtiva da agricultura. Os baixos incentivos dos preços externos das "commodities" agrícolas, a autosuficiência dos principais países importadores e a queda da demanda externa em face dos problemas de endividamento e escassez de divisas são alguns indicadores explicativos do quadro atual.

O maior dinamismo do mercado interno passa a ser o principal motor do crescimento da economia brasileira, impulsionado por incentivos vindos do próprio mercado. A evolução mais favorável dos termos de troca domésticos e os preços internos mais atraentes trouxeram, como conseqüência, a melhoria da produção para consumo interno.

GOLDIN \& RESENDE (1993) constatam, considerando os periodos de 1973/81 a 1979/89, um aumento das taxas anuais de crescimento da produção de produtos de mercado interno, como arroz, feijão, milho, trigo, algodão e cana-de-açúcar, e perda de dinamismo da produção de soja.

1 LOPES, M. R., 1987; MANOEL, A. \& BARROS, J.R.M., 1987; DIAS, G.L.S, 1989; RESENDE, G.C., 1988; GOLDIN, J. \& RESENDE, G.R., 1993. 
Excetuando algumas safras (1980/81 e 1986/87), os indices de crescimento da produção dos exportáveis têm sofrido reduções. Estatísticas do volume exportado no periodo de 1977 a 1985 mostram decréscimos de alguns produtos, como cana-de-açúcar (9\%) e mamona (50\%); constância no volume exportado de outros, como café e cacau; e evolução crescente apenas para o suco de laranja (14\%) (MANOEL \& BARROS, 1987).

Em sintese, os produtos comercializáveis no mercado internacional,-que lideravam o processo de expansão do produto agricola, perderam posição relativa para os produtos não-comercializáveis. A agricultura passou a manter seu crescimento explorando o potencial representado pelo mercado interno. A modernização tecnológica da atividade agrícola, que possibilitou a elevação da produtividade da terra e do trabalho, e mais recentemente 0 dinamismo da agroindustria 1 responderam, parcialmente, pela nova performance da agricultura dos anos 80 .

Foram fundamentais para direcionar a agricultura brasileira para o mercado interno, além das mudanças ocorridas no comércio mundial como preços desestimuladores $^{2}$, os desajustes causados ao setor exportador agrícola pelas políticas comercial (taxações explícitas e implícitas) e macroeconômica (altas taxas de juros e redução dos financiamentos). Da mesma forma, a política cambial, cujas desvalorizações concedidas exauriaram-se rapidamente em razão da alta da inflação, afetou de forma significativa o desempenho das exportaçōes agrícolas. Nesse contexto, o valor das exportações agricolas tem apresentado tendência generalizada de redução do seu ritmo de crescimento, mais acentuadamente no sub-setor de exportáveis tradicionais. MAINON et alii (1991), analisando o comportamento da produção agrícola na década de 80; verificaram a expansão da produção de alimentos básicos (feijão, milho, arroz e mandioca) e de culturas voltadas para a substituição de importações (trigo e cana-de-açúcar). Embora a quantidade produzida dos bens agricolas exportáveis analisados (soja, laranja, cacau e café) tenha também se expandido, o valor exportado

1 Nesse estudo considera-se como agroindústria a adaptação dos processos produtivos do setor agropecuário aos processos produtivos da indústria de transformação (SZMRECSANYI, 1990).

2 Tomando 0 ano de $1980=100$, os preços reais dos produtos agrícolas básicos comercializados no mercado externo situaram-se, em média, no período de 1970 a 1979 , $21,5 \%$ acima dessa base e $17,3 \%$ abaixo durante a década de 80 , de acordo com dados das Estatísticas Financeiras Internacionais de dezembro de 1989. 
não seguiu a mesma tendência, em razão da já mencionada conjuntura adversa do mercado internacional de "commodities".

Essa perda de dinâmica das exportações brasileiras configura, para os anos 80 , uma realidade diferente da experimentada na década de 70 . De um contexto de liderança da agricultura de exportação, impulsionada por preços internacionais favoráveis, por incentivos financeiros à produção e por investimentos em inovações tecnológicas, além da influência indireta dos incentivos às exportações de produtos industrializados, passou-se, na década de 80 , para um novo cenário: a perda de espaço no mercado internacional de produtos antes importantes na pauta das exportações agricolas brasileiras. Como exemplo, LOPES (1987) cita os casos do arroz, do milho e do algodão, cujo abastecimento interno passou a ser, com freqüência, dependente de importações. Evidência clara desse fenômeno são os picos da importação brasileira de grãos ocorridos ao final da década de 70, em 1986 e no inicio da década de 90 (JANK, 1994).

Condições externas de recessão mundial e aumento do protecionismo por parte dos paises desenvolvidos trouxeram conseqüências importantes para o quadro evolutivo das exportações brasileiras na década de 80. MANOEL \& BARROS (1987) chamam a atenção para o acúmulo de estoques mundiais de produtos agricolas na primeira metade dos anos 80 e para o decréscimo das importações de bens nos EUA e na UE (União Européia).

O reforço das estratégias protecionistas dos paises desenvolvidos que concentraram investimentos no setor agricola encontrou justificativa nos preços relativamente altos dos alimentos no mercado mundial na década de 70 , com destaque para o "commodity boom" de 1973/74, e nas dificuldades de importação pelos paises não-produtores de petróleo. Na segunda metade dessa década, os estoques mundiais de alimentos já apresentavam um crescimento de 53\% (IGLESIAS, 1990), assumindo proporções maiores durante os anos 80.

Internamente, em razão dos planos mais recentes de ajustamento econômico (a partir de 1986) impostos à economia brasileira, que puseram fim ao sistema de financiamentos a taxas subsidiadas e reduziram os gastos públicos e outros incentivos à modernização, ficou cada vez mais difícil para o Brasil gerar superávits comerciais agricolas. Este cenário atual tem raizes históricas, por não ter 0 desenvolvimento do setor ocupado espaço prioritário na formulação das estratégias 
econômicas dos sucessivos planos governamentais postos em prática desde a Segunda Guerra Mundial.

Analisando o setor exportador agricola, HOMEM DE MELO (1979) confirma essa ausência de estímulos desde 1946, apesar do já evidente desequilibrio do balanço de pagamentos. Além do declínio da taxa de câmbio real, as exportações agricolas eram controladas por um sistema de licenciamento prévio e, mais tarde, por cotas, impostos e proibições.

Há certo consenso entre os trabalhos que analisaram a politica agricola no Brasil sobre a histórica taxação ao setor exportador. Apesar das políticas setoriais destinadas à agricultura, como preços mínimos, crédito rural e programas específicos de fomento, as políticas macroeconômicas afetaram a agricultura de exportação de forma mais intensa. Os profundos efeitos que essas politicas exerceram sobre os preços relativos e sobre a lucratividade da agricultura influenciaram, negativamente, 0 crescimento do setor com conseqüentes efeitos alocativos, que, em geral, atuaram no sentido contrário ao das politicas setoriais, com significativo desperdicio de recursos. A política de promoção das exportações do periodo pós-64 foi direcionada para o setor de manufaturas, excluindo a agricultura que, não só continuou participando marginalmente do comércio exterior, como também sofreu uma taxação implícita, dado o desvio de recursos para a atividade subsidiada. A melhor performance das exportações agricolas na década de 70 não é explicada por politicas diretas de incentivo, mas" por um conjunto de fatores, como melhoria do preço internacional das "commodities" e efeitos da modernização estimulada pelas políticas setoriais que induziam a utilização de insumos industriais. Esses incentivos que sustentaram 0 crescimento do setor foram gradualmente abandonados nos anos 80 , em virtude do quadro internacional recessivo.

A queda da taxa de câmbio real, a partir de 1987 (ver dados em ZINI JR., 1989), e suas acentuadas oscilaçōes nos últimos anos são apontadas como fundamentais para o comportamento das exportações brasileiras. A sobrevalorização da taxa de câmbio real tornou-se mais acentuada a partir do final de 1988, tendo esse indicador atingido o mais baixo nivel no inicio de 1990, acumulando um atraso cambial de $43,9 \%$ (OLIVEIRA \& SILVA et alii, 1993). A partir dai, iniciou-se um periodo de oscilações ainda mais acentuadas: após a desvalorização ocorrida no final de 1990 e início de 1991, passou-se por um rápido periodo de deterioração cambial até meados de 
1991, quando ocorreu novamente uma inversão e o câmbio real sofreu outra tendência de alta, porém de curta duração.

Além da política cambial, LOPES (1992) identifica outros fatores que fazem com que o Brasil tenha um forte viés antiexportador: a política comercial protege os insumos, tributa as exportações e isenta as importações subsidiadas. Em tomo de 40 a $50 \%$ da renda agricola é transferida para os Estados e para os importadores que pagam menos pelo câmbio do que pagariam numa situação de câmbio ajustado.

Em sintese, as exportações de produtos agricolas tiveram por parte da política governamental um tratamento diferenciado do que foi dado aos produtos manufaturados, não tendo usufruido, especialmente nas últimas décadas, de políticas de incentivo, ao contrário, sofreram restrições impostas por medidas governamentais. Com o objetivo de controlar os preços dos alimentos e produzir superávits, sem elevar os preços internos, as autoridades vêm fazendo uso da política cambial, de impostos de exportação e de controle de preços.

Diferentes fatores contribuiram para a conformação desse contexto de crescimento e crise do setor exportador agricola brasileiro. A alternância de modelos de desenvolvimento fechados e liberalizantes, contrastando medidas de estímulo do crescimento das exportações com políticas de valorização do mercado interno, e as condições externas prevalecentes em diferentes momentos forçaram o setor aos ajustes necessários para enfrentar as crises.

Assim, a tendência do novo padrão de crescimento agricola dos anos 80 , de maior valorização do mercado interno, faz parte dessa dinâmica de ajuste que, ao mesmo tempo, incorpora um processo de redução do ritmo de crescimento das exportações.

O que se quer destacar, a partir desta análise geral que evidencia a perda da importância relativa da atividade exportadora agricola, é a transformação que vem ocorrendo simultaneamente a esse processo no sentido do incremento da atividade agroindustrial. O sub-setor exportador está passando por uma substancial mudança de sua estrutura para maior diversificação da pauta em que passam a liderar "commodities" com maior valor adicionado ou maior grau de transformação industrial, como farelos, pastas, suco de laranja, papel, tecidos e peles/couros. 
A expansão mais rápida de alguns setores agroindustriais vem configurando, desde o início da década de 80 , uma nova natureza de inserção do Brasil no cenário internacional, mais eficiente e competitiva. A conquista de posições mais sólidas num mercado mais competitivo exige maior sofisticação dos padrões tecnológicos de produção e de processamento industrial e maior capacidade de diferenciação de produtos na busca de novas vantagens comparativas dinâmicas, com potencial para serem exploradas em nichos de alta tecnologia.

PAULA (1993) analisa essa questão como "uma dinâmica recente qưe acaba depositando na capacidade das empresas processadoras internas uma importância maior, em termos de conquista de mercado, do que nas empresas apenas exportadoras, em grande parte voltadas para mercados já saturados e altamente protegidos".

A realidade avança na eficiência tecnológica e no processo de integração e liberalismo econômico. O comércio agricola mundial e, conseqüentemente, o brasileiro sofrem influência crítica do protecionismo dos grandes blocos econômicos e das barreiras comerciais em geral. Decisões importantes começam a ser tomadas pelo Brasil no sentido da liberalização como redução tarifária e de subsídios, embora tais decisões sejam ainda incipientes para reverter um sistema mais voltado para uma economia fechada. A integração econômica já è também uma realidade com a formação do Mercado Comum do Cone Sul (MERCOSUL), cujo objetivo é impulsionar as transações intra-bloco (Brasil, Argentina, Paraguai e Uruguai), por meio do estabelecimento da tarifa zero, e com o resto do mundo pela fixação da tarifa externa comum.

A abertura externa valoriza a competitividade, cujos elementos essenciais são a incorporação de progresso tecnológico e o domínio da tecnologia a que está atrelada a eficiência do sistema agroindustrial. Pode-se observar, então, a reorganização da estrutura da pauta de exportações, em que passam a surgir, como eixos dinâmicos, os sub-setores que conseguiram avançar na maior incorporação de valor ao produto.

Dados apresentados por JANK (1990) mostram que os produtos agricolas tradicionais (açúcar, café, cacau e algodão) passaram de uma participação de $70 \%$ das exportações totais da agroindústria no inicio da década de 70 para menos de $30 \%$ no início da década de 90, e que novos complexos agroindustriais ganharam maior espaço no mercado mundial, especificamente os produtos com maior agregação de valor. 
PFEIFER FILHO (1990) destaca a agroindústria como um sub-setor de dupla importância, conquistando mercados externos e garantindo o abastecimento intemo.

$\mathrm{Na}$ realidade, as exportações de produtos agricolas semi-industrializados começaram a expandir-se desde o final dos anos 60 , aproveitando a política econômica mais liberalizante e a promoção das exportações de manufaturados. Na década de 70 , a taxa média de crescimento do valor das exportações de produtos da agroindústria chegou a 19\% a.a., tendo este sub-setor passado por substancial diversificação (GOLDIN \& RESENDE, 1993). Ao final dos anos 80, as exportações de produtos industrializados, do Pais atingiram quase US\$ 25 bilhões a.a., estacionando as exportações de produtos básicos em cerca de US $\$ 10$ bilhões (JANK,1990).

De alguma forma, essa crescente diferenciação representa uma estratégia para evitar a pesada tributação que recai sobre a categoria de produtos agrícolas primários. Resultados apresentados por Oliveira (1983) e Wemeck (1984), citados por GOLDIN \& RESENDE (1993) comprovam que a adição de valor ao produto acarreta redução nos tributos pagos à exportação, que varia de $10.5 \%$ a $31.6 \%$. Assim, a indústria de transformação beneficia-se de preços mais baixos da matéria-prima (produtos "in natura"), que tem exportação controlada e carga tributária mais pesada.

Partindo da percepção dessa nova dinâmica de inserção do Brasil no mercado internacional, que se caracteriza por uma tendência de mudança na estrutura da pauta, em termos de diferenciação de produtos, e da pressuposição de que uma base consistente de crescimento econômico passa por uma integração competitiva, das atividades produtivas aos fluxos do comércio externo, as perspectivas deste trabalho são analisar o comportamento das exportações agroindustriais brasileiras nas últimas décadas (periodo de 1971 a 1992), no contexto dessas transformações, e os principais fatores que direcionaram o Pais ao novo posicionamento no mercado internacional.

A determinação da tendência do fluxo do comércio agricola brasileiro no mercado mundial tem de importância para o conhecimento dos espaços e as oportunidades de crescimento que poderiam ser conquistados pelo capital agroindustrial nas próximas décadas, por meio de estratégias ofensivas que impliquem a expansão da capacidade de ocupar novos mercados, em face da ordem e da estrutura atuais do comércio mundial. 
Com esses objetivos, este trabalho apresenta, inicialmente (Capitulo 2), uma análise do desempenho e da evolução da estrutura da pauta de exportações brasileira, considerando cada complexo agroindustrial exportado e também em nivel agregado, a partir da classificação dos produtos em básicos, semimanufaturados e manufaturados, de forma a verificar as principais tendências ocorridas nos padrões do comércio do Brasil com o exterior.

Em seguida (Capitulo 3), à semelhança do procedimento adotado para o Brasil, faz-se um diagnóstico das tendências das exportações mundiais, considerando os principais mercados continentais e, ou, blocos econômicos, por complexo agroindustrial e também para os três agregados básicos, semimanufaturados e manufaturados. A análise em nivel mundial tem importância, uma vez que permite comparar os fenômenos ocorridos no Brasil com os observados no resto do mundo, ou seja, verificar se existe especificidade na dinâmica de comportamento da pauta de exportações brasileiras impulsionada por fatores internos e,ou, externos, ou se esta reflete apenas a tendência do mercado mundial.

Os fatores que tiveram influência nesse processo de mudança são detectados com a aplicação do método de Constant-Market-Share, que permite decompor os principais indicadores de fontes de crescimento das exportações. No Capitulo 4 faz-se uma descrição desse método, justificando as principais vantagens e limitações de sua utilização e discutem-se os resultados empíricos obtidos.

A análise é complementada pelo cálculo dos coeficientes de vantagem comparativa revelada, que tem por objetivo detectar que produtos vêm dominando a estrutura da pauta de exportações brasileiras ao longo do tempo. O Capitulo 5 apresenta as principais conclusões do trabalho. 


\section{EVOLUÇÃO DA ESTRUTURA DA PAUTA DE EXPORTAÇÕES DA AGROINDÚSTRIA BRASILEIRA}

\subsection{INTRODUÇÃO}

As principais tendências que marcaram a evolução da estrutura da pauta de exportações da agroindústria brasileira dos anos 70 até os primeiros anos da década de 90 são analisadas neste capitulo, a partir de um conjunto de dados agregados e desagregados, de taxas geométricas médias de crescimento, e de análise gráfica.

Faz-se, de inicio, uma análise geral considerando as exportações totais da agroindústria, quanto ao valor $e$ à quantidade exportada $e$, posteriormente, os dados são desagregados em grupos de produtos básicos, semimanufaturados e manufaturados ${ }^{1}$.

O objetivo de analisar a pauta de exportações agroindustriais brasileira a partir destes agregados relaciona-se com aspectos abordados no capitulo introdutório sobre o processo de redirecionamento por que vem passando a estrutura dessa pauta. Este processo, embora não pareça avançado, nem consolidado, permite perceber a emergência de um padrão de exportações no qual começam a sobressair e ganhar espaço no mercado internacional produtos com maior grau de transformação industrial, produtos da agroindústria

\footnotetext{
${ }^{1}$ Os produtos que compõem cada grupo estão relacionados no Apêndice 1, de acordo com classificação adotada pela FUNCEX.
} 
classificados como semimanufaturados e manufaturados, ao mesmo tempo em que as exportações de produtos básicos passam por uma relativa desaceleração.

A análise das exportações dos principais complexos agroindustriais é feita posteriormente, em separado, procurando identificar produtos específicos que foram surgindo como novos exportados ou já exportados, mas que adquiriram maior dinamismo exportador e passaram a ter participação mais destacada na pauta.

Essas mudanças vêm sendo impulsionadas por uma série de fatores, como os processos de ajustamento macroeconômico e os choques externos das últimas décadas, que tiveram influência marcante na conformação do que é hoje o setor agroexportador brasileiro. As inter-relações entre esses fatores e as mudanças observadas a partir da análise empirica são importantes para a compreensão desse processo que está em curso.

Foram considerados na análise 13 complexos agroindustriais que atualmente representam quase a totalidade do valor das exportações brasileiras do setor: soja $(27,0 \%)$, café $(19,8 \%)$, madeira $(9,0 \%)$, laranja $(11,0 \%)$, came bovina $(8,9 \%)$, cacau $(4,3 \%)$, açúcar $(3,5 \%)$, fumo $(4,6 \%)$, algodão $(3,7 \%)$, castanha-de-caju (1,2\%), pimenta $(0,5 \%)$, frango $(2,0 \%)$ e pesca $(1,5 \%)$. A relação dos subprodutos que compõem cada complexo encontra-se no Apêndice 2.

A série de dados abrange o periodo de 1971 a 1992, estando em média móvel de três anos e dividida em três subperiodos: 1971/81, 1982/87 e 1988/92, de forma a caracterizar os distintos momentos no processo evolutivo do valor das exportações agroindustriais brasileiras. Estão representados, respectivamente, uma fase de crescimento acelerado, um periodo de relativa estagnação e outro de retrocesso (anos mais recentes).

A análise da dinâmica exportadora, ao longo de cada periodo, é feita a partir de estimativas de equações de tendência e cálculo de taxas geométricas de crescimento para cada produto que compõe os complexos agroindustriais e para os três agregados. 


\subsection{TENDÊNCIAS GERAIS DA PAUTA DE EXPORTAÇÕES}

Os dados sobre a evolução das exportaçōes brasileiras totais de produtos da agroindústria, apresentados na Tabela 1 e Figura 1, quando analisados em termos de "quantum" exportado, mostram uma tendência geral crescente até a primeira metade dos anos 80 , quando sofrem uma desaceleração, revertida ao final dessa década e início dos anos 90 . As exportações em valor têm um comportamento diferente: crescem de forma acelerada na década de 70 até 1980/81, passando por uma expressiva queda em 1982/83, e posterior estagnação com decréscimos registrados, ao final da década de 80 e nos primeiros anos de 90 .

As taxas geométricas de crescimento, estimadas para o período como um todo, expressam essa mesma tendência geral, uma vez que são positivas e quantificam um crescimento médio anual de $4,0 \%$ para a quantidade $e$ de apenas 1,2\% quando se considera o valor exportado (Tabela 2). Essa não é, no entanto, uma tendência linear, uma vez que as taxas apresentam valores diferentes para os diferentes subperiodos quando a série de dados é desagregada. A partir do periodo de 1971/81, em que o valor das exportações totais apresentou um acelerado crescimento com taxa geométrica média de 7,8\% a.a., seguiu-se uma fase de decréscimo e posterior estagnação (1982/87) em que a taxa correspondente foi estatisticamente igual a zero. No periodo seguinte, as exportaçōes brasileiras passaram pela pior fase (1988/92) atingindo decréscimo médio de $-5,4 \%$ a.a. Se se considerar a subdivisão em dois periodos, 1971/81 e 1982/92, pode-se perceber a disparidade da evolução do valor exportado entre as duas décadas. De um crescimento médio de $7,8 \%$ em 1971/81, passou-se, na década seguinte, para uma fase de estagnação expressa pela taxa de crescimento igual a zero.

O comportamento do valor exportado reflete, de certa forma, o comportamento dos preços dos produtos no mercado internacional. Verifica-se na Figura 2 que estes mantiveram-se num nivel relativamento alto na década de 70 , passaram por uma queda acentuada em 1981/82 e tiveram, a partir dai, pequenas oscilações anuais que caracterizaram um periodo de estabilidade até 1988/89. É 


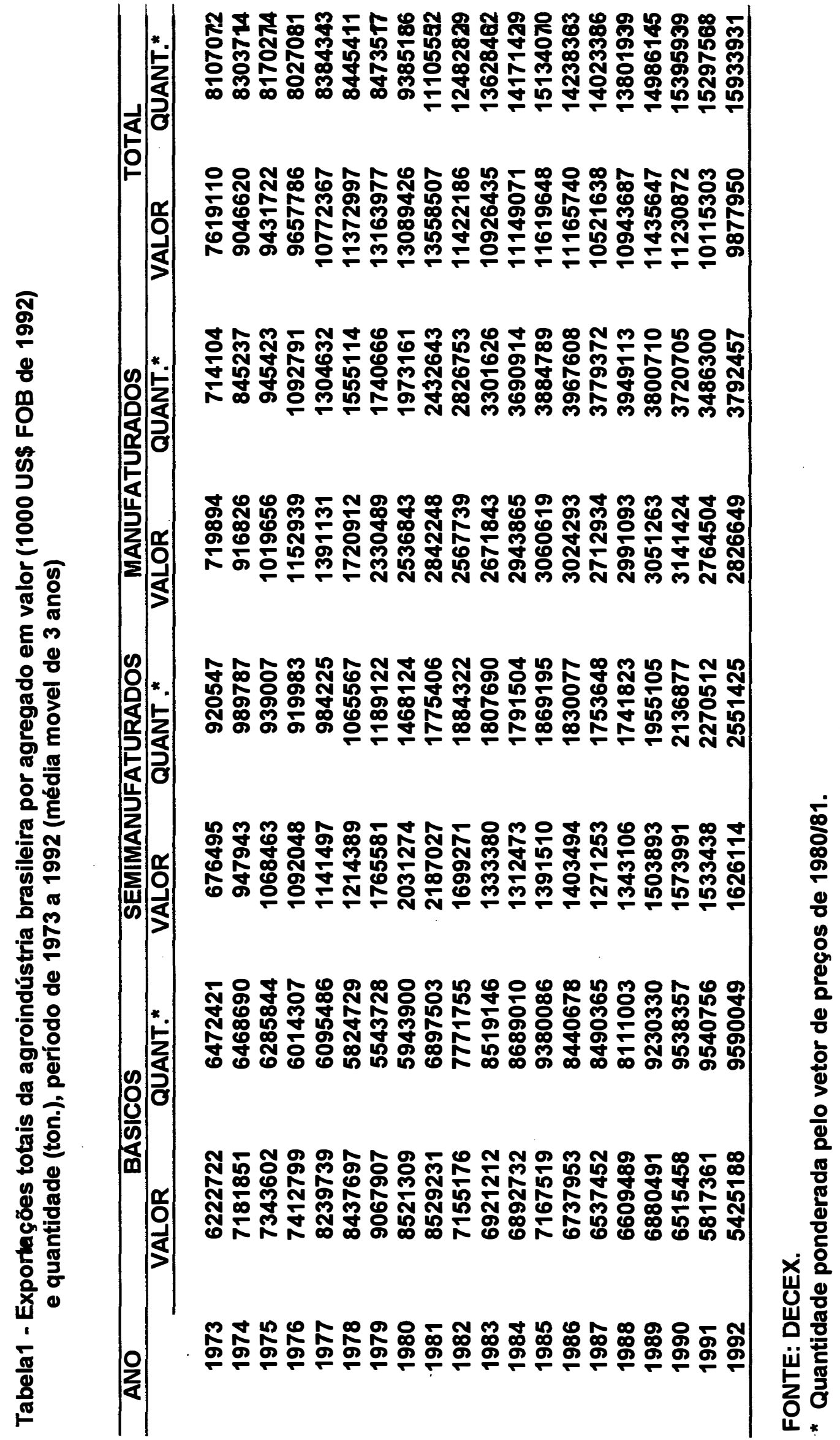




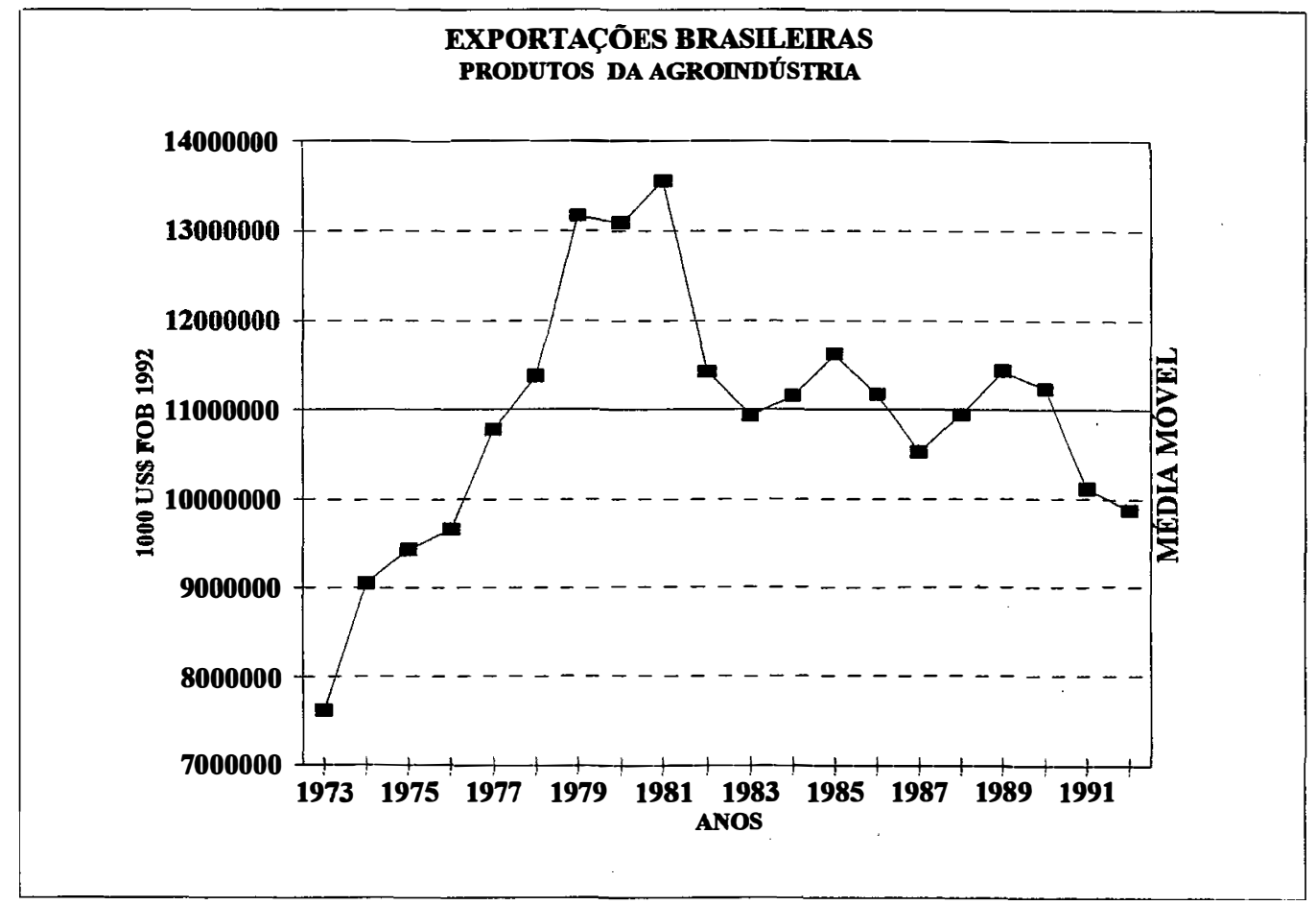

(a)

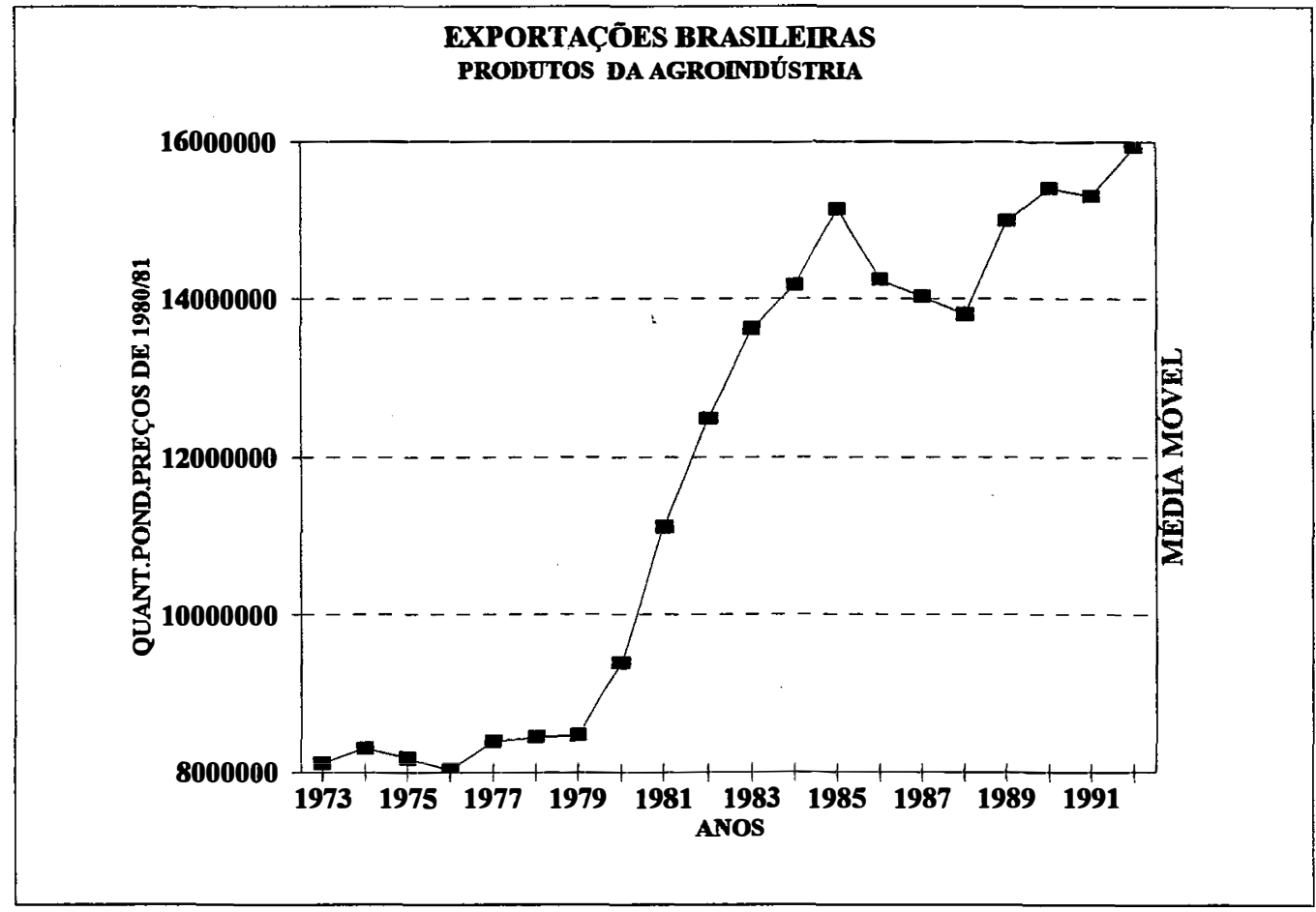

(b)

Figura 1 - Exportações totais da agroindústria brasileira em valor (a) e quantidade (b) 


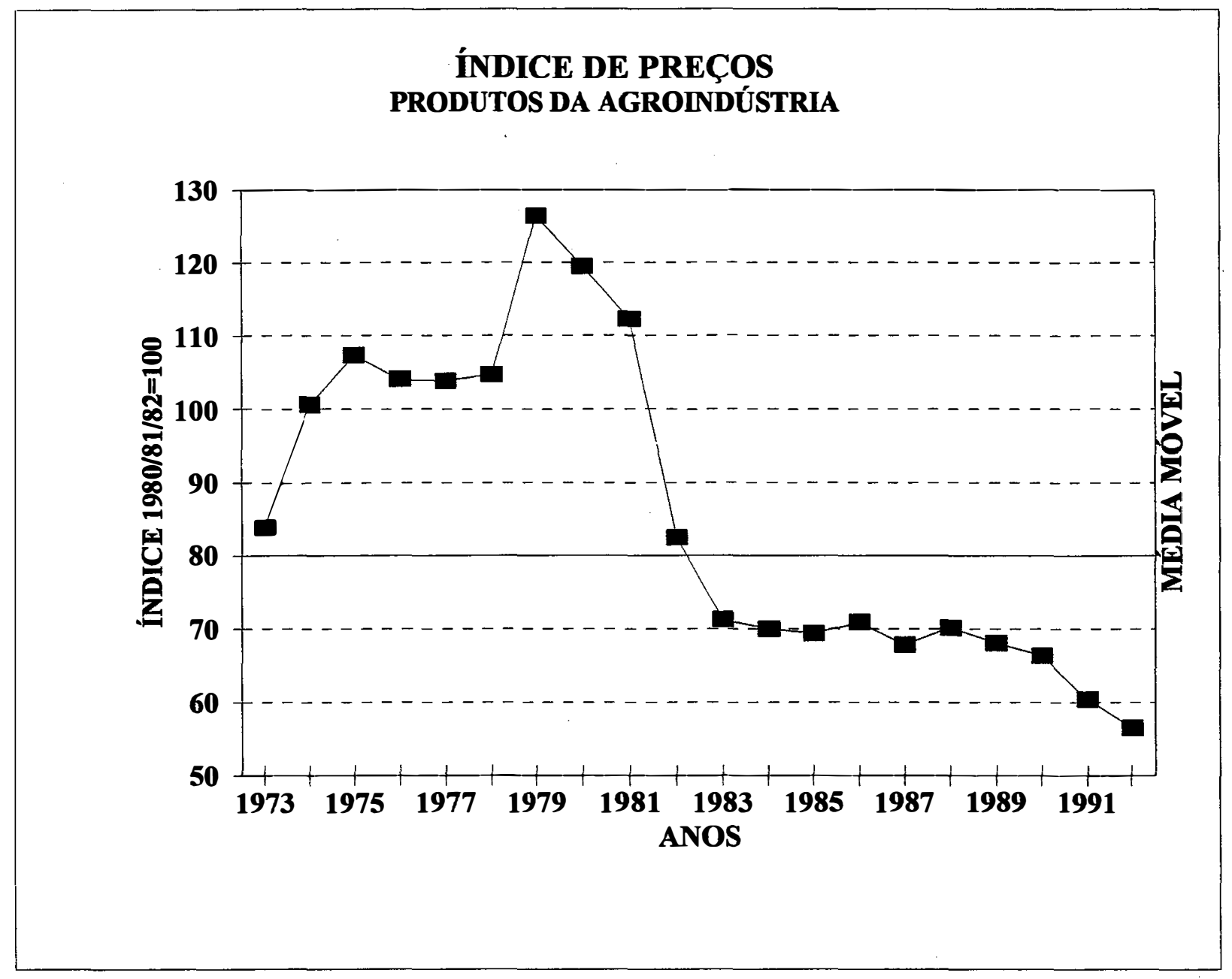

Figura 2 - Índice de preços externos dos produtos exportados pela agroindústria brasileira 
nítido, desde então, o processo de decréscimo dos preços, que perdurou até 1992.

Em termos de "quantum" exportado, a análise por subperiodo confirma as diferenças de comportamento em relação ao valor: a tendência de queda só foi observada em meados da década de 80 e a retomada do crescimento no final desta década e no início dos anos 90 , quando o valor exportado já era declinante, ocorreu a taxas decrescentes, ou seja, essa tendência não teve a mesma intensidade verificada no final de 70 e na primeira metade de 80.

Tabela 2 - Taxa geométrica média de crescimento do valor e da quantidade exportados pela agroindústria brasileira, em \%, no período de 1971/ 92.

\begin{tabular}{|c|c|c|}
\hline \multirow{2}{*}{$\begin{array}{l}\text { Períodol } \\
\text { Subperíodo }\end{array}$} & \multicolumn{2}{|c|}{ Taxa Geométrica Média Anual de Crescimento (\%) } \\
\hline & Valor Exportado & Quantidade Exportada \\
\hline $1971 / 92$ & $1,22^{*}$ & $3,96^{\star \star}$ \\
\hline $1971 / 81$ & $7,80^{\star \star}$ & $3,48^{\star \star}$ \\
\hline $1982 / 87$ & $0,14^{\text {ns }}$ & $0,11^{\mathrm{ns}}$ \\
\hline $1988 / 92$ & $-5,40^{\star}$ & $1,85^{\star}$ \\
\hline $1982 / 92$ & $-0,78^{n s}$ & $1,47^{\star \star}$ \\
\hline
\end{tabular}

\footnotetext{
* significativo de 5 a $15 \%$;

** significativo a $5 \%$, e

ns não-significativo.
}

A análise agregada, embora importante para se visualizar o panorama geral da evolução do setor agroexportador brasileiro ao longo dos anos, não permite conhecer a dinâmica do comportamento dos grupos de produtos ou de produtos específicos. É fundamental avaliar como cada sub-setor foi sendo atingido e se ajustando à instabilidade interna e aos choques externos, e, nesse processo, quais produtos sofreram impactos mais fortes de forma a influenciar o comportamento das exportações totais. 
A mudança estrutural que acompanhou a evolução das exportações e suas inter-relações com fenômenos econômicos conjunturais pode ser percebida com maior clareza, na medida em que a composição da pauta é analisada quanto a cada agregado que a compõe.

\subsection{TENDÊNCIA DAS EXPORTAÇÕES POR AGREGADO DE PRODUTO BÁSICOS, SEMIMANUFATURADOS E MANUFATURADOS}

A tendência geral de evolução das exportações dos grupos de produtos básicos, semimanufaturados e manufaturados revela uma série de aspectos não-observados na análise global. As tabelas com os dados correspondentes encontram-se no Apêndice 3.

Há uma semelhança de comportamento entre 0 valor das exportações dos três agregados (Figuras 3a, 4a e 5a) e o valor total exportado na década de 70 , quando houve um periodo de crescimento generalizado das exportações brasileiras, incentivado, basicamente, por preços intemacionais estimuladores. As taxas geométricas médias de crescimento ao ano para este periodo apresentaram valores altos e positivos, que expressam essa tendência: básicos: 4,5\%, semimanufaturados: $15,0 \%$ e manufaturados: 19,1\% (Tabela 3). Seguiu-se uma queda do valor exportado no início dos anos 80 e uma fase posterior de relativa estagnação (1982/88), como registrado também na análise das exportações totais.

De 1988 a 1992, no entanto, foi particularmente nitida e diferenciada a dinâmica de comportamento dos três agregados. Verificou-se, claramente, o acentuado decréscimo do valor exportado dos produtos básicos, que perdurou até o final do período. Comportamento inverso ocorreu com os semimanufaturados, cuja retomada de crescimento foi observada a partir de 1988. A evolução das exportações de manufaturados apresentou também tendência de crescimento neste periodo, embora com ligeira queda no inicio da década de 90 , mas houve uma certa tendência de recuperação a partir de 1991. 


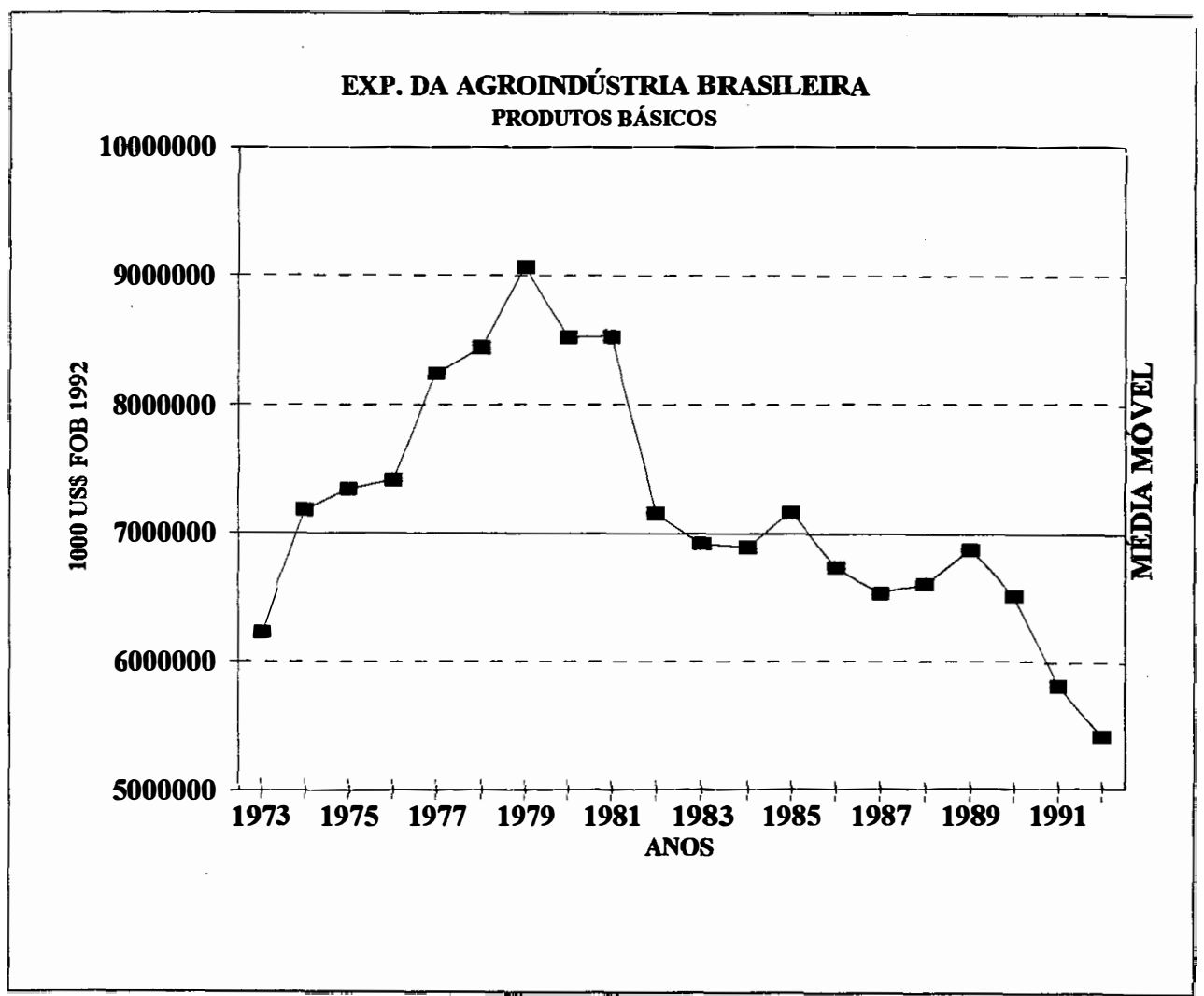

(a)

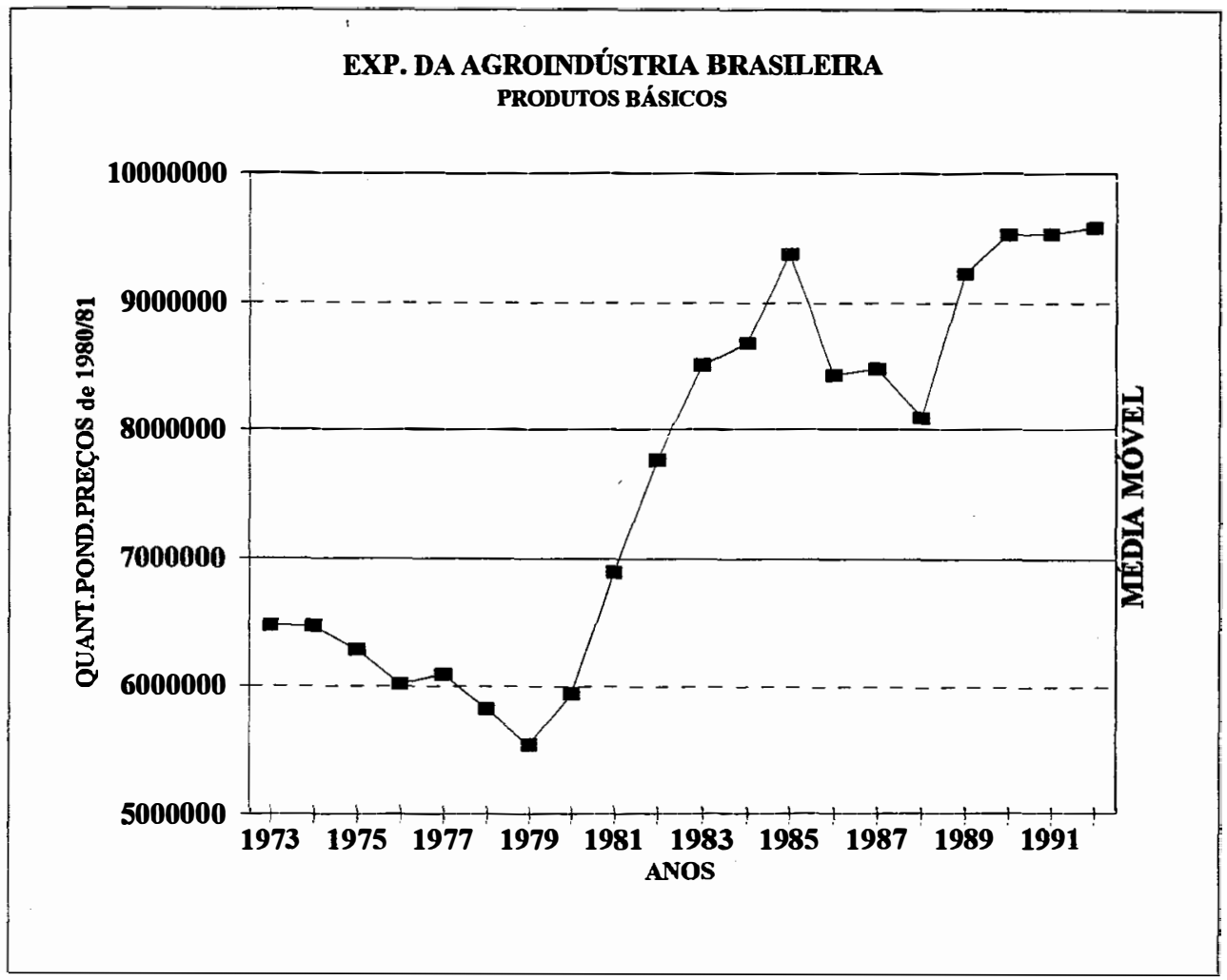

(b)

Figura 3 - Exportações da agroindústria brasileira de produtos básicos, em valor (a) e quantidade (b) 


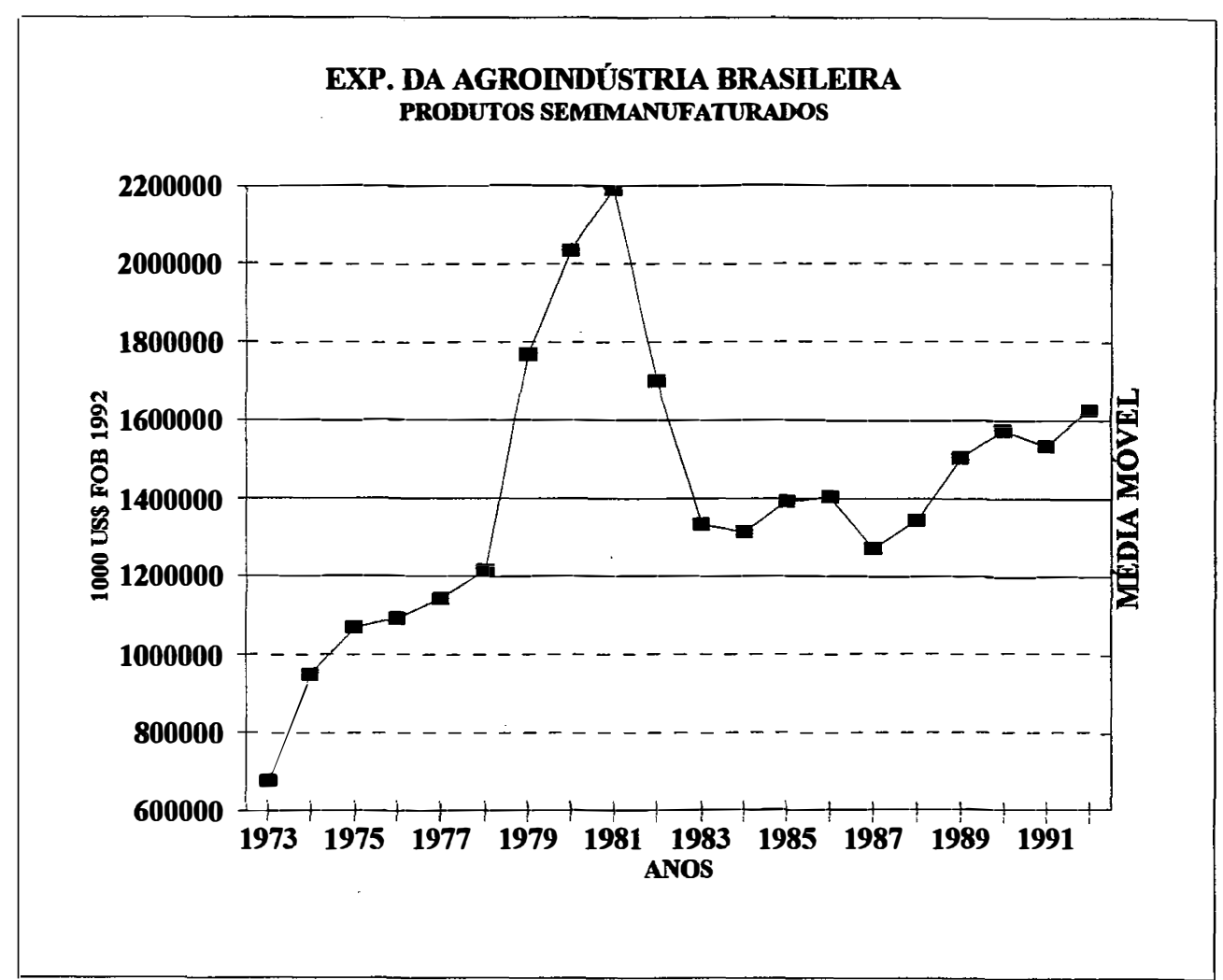

(a)

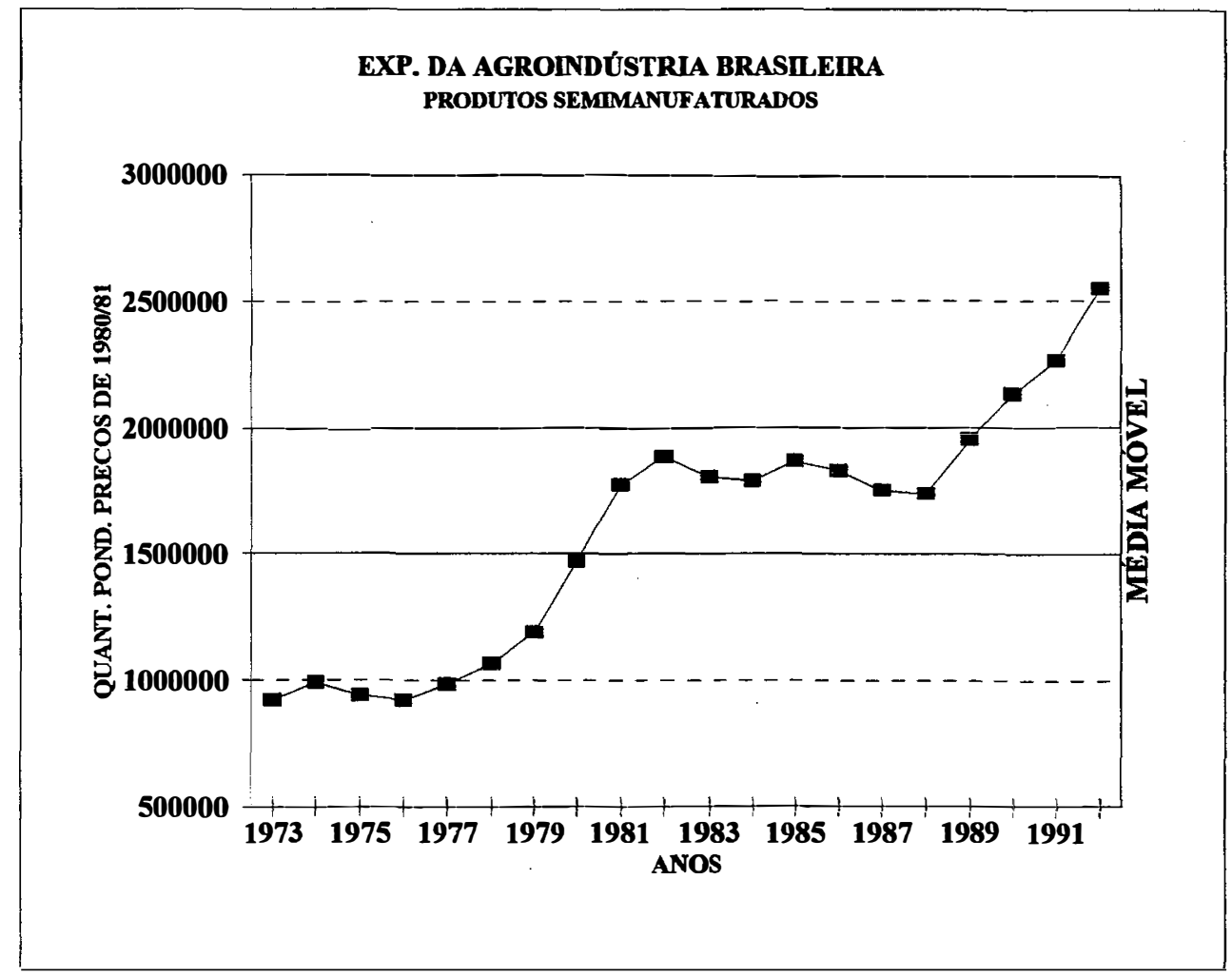

(b)

Figura 4 - Exportações da agroindústria brasileira de produtos semimanufaturados em valor (a) e quantidade (b) 


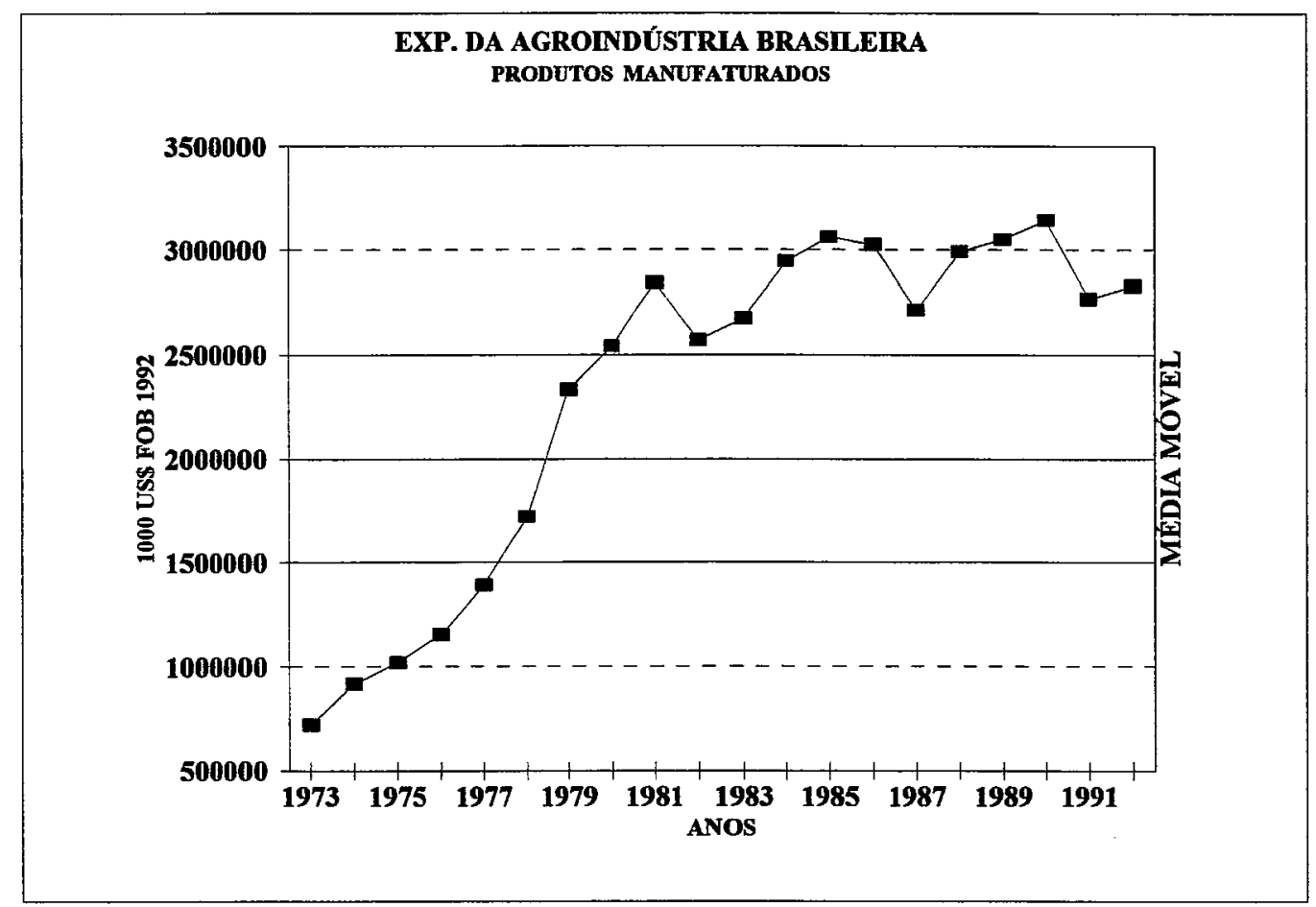

(a)

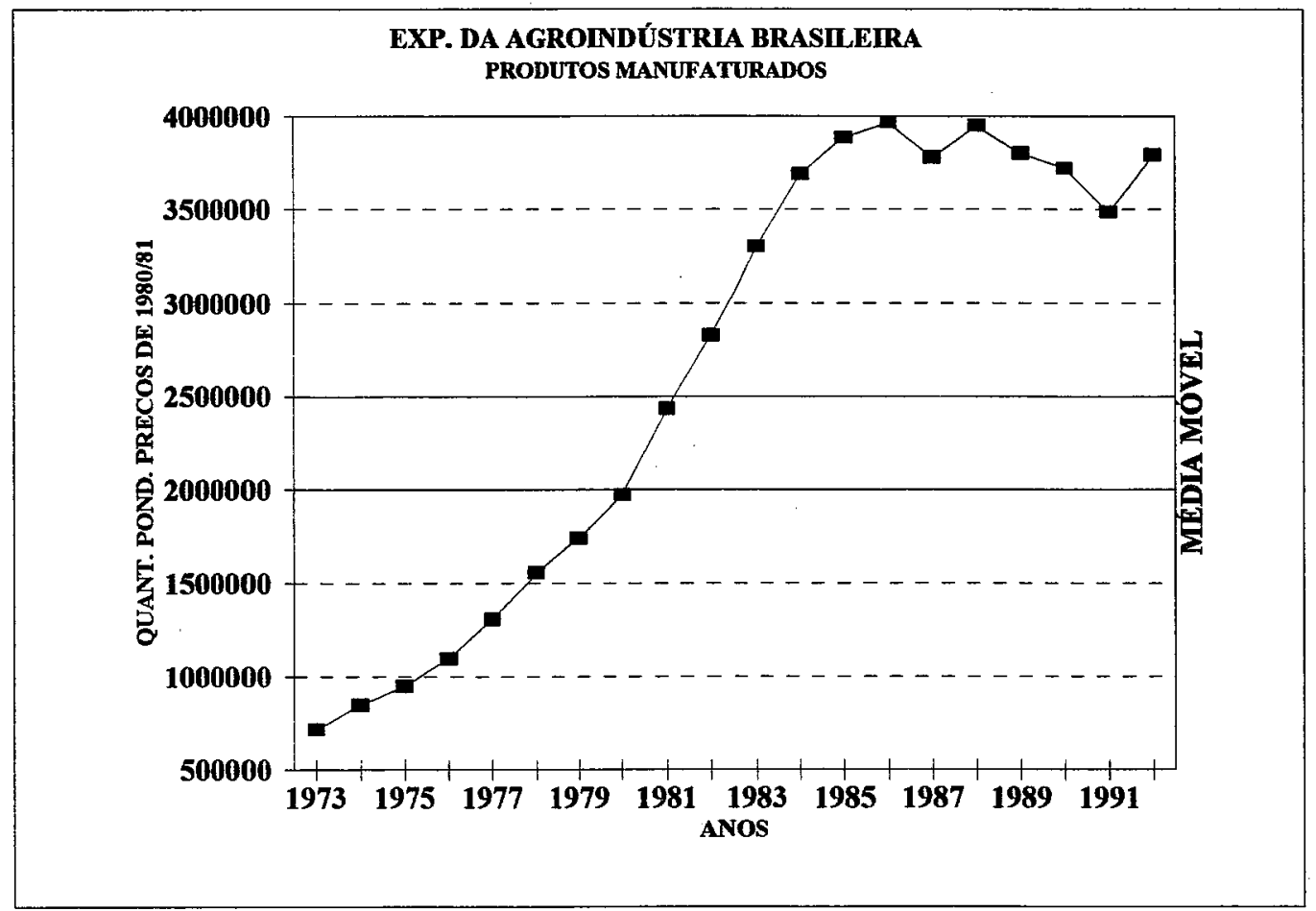

(b)

Figura 5 - Exportações da agroindústria brasileira de produtos manufaturados, om valor (a) e quantidade (b) 
A queda mais acentuada dos preços dos produtos básicos (Figura 6) desde 0 início da década de 80 , e sobretudo a partir de 1988 , foi um fator explicativo do decréscimo do valor exportado desse agregado no referido período.

Os indices de preço dos exportáveis semimanufaturados e manufaturados, embora tenham oscilado muito em todo o periodo, com clara tendência de decréscimo especialmente nos últimos anos, registraram variação de intensidade menor do que a verificada no índice de preço dos básicos.

Tabela 3 - Taxa geométrica média anual de crescimento das exportações brasileiras por agregado, em \%, no periodo de 1971/92.

\begin{tabular}{|c|c|c|c|c|c|c|}
\hline & & \multicolumn{2}{|c|}{ TOTAL } & \multicolumn{2}{|c|}{ SUBPERIOODOS } & \multirow[b]{2}{*}{$1982 / 92$} \\
\hline \multicolumn{2}{|c|}{ AGREGADO } & $1971 / 92$ & $1971 / 81$ & $1982 / 87$ & $1988 / 92$ & \\
\hline \multicolumn{7}{|l|}{ Básicos } \\
\hline & Valor & $-0,75^{\text {ns }}$ & $4,48^{\star \star}$ & $-0,96$ ns & $-7,68^{\star \star}$ & $-2,32^{\star \star}$ \\
\hline & Quantidade & $2,77^{\star \star}$ & $1,10 \mathrm{~ns}$ & $-1,10^{\text {ns }}$ & $1,11^{\text {ns }}$ & $1,40^{\text {ns }}$ \\
\hline \multicolumn{7}{|c|}{$\begin{array}{l}\text { Semimanufa- } \\
\text { turados }\end{array}$} \\
\hline & Valor & $3,46^{\star \star}$ & $14,90^{\star \star}$ & $2,18^{\text {ns }}$ & $2,56^{\mathrm{ns}}$ & $3,79^{\star *}$ \\
\hline & Quantidade & $5,70^{\star \star}$ & $8,90^{\star \star}$ & $0,08^{\text {ns }}$ & $10,59^{\star \star}$ & $4,74^{\star \star}$ \\
\hline \multicolumn{7}{|c|}{ Manufaturados } \\
\hline & Valor & $7,40^{\star \star}$ & $19,13^{\star \star}$ & $0,98^{\text {ns }}$ & $-4,83^{n s}$ & $0,40^{n s}$ \\
\hline & Quantidade & $9,90^{\star \star}$ & $17,47^{\star *}$ & $2,97^{\star}$ & $0,96^{\mathrm{ns}}$ & $0,80^{n s}$ \\
\hline
\end{tabular}

* significativo de 5 a $15 \%$;

** significativo a $5 \%$ e

ns não-significativo.

Diferenças de comportamento entre os três agregados, mais acentuadas nos anos recentes, são observadas também a partir dos valores das taxas geométricas anuais de crescimento, calculadas para os subperiodos (Tabela 3). O decréscimo do valor das exportações de 1971/81 para 1982/92 (entre as duas décadas) foi generalizado, chegando a apresentar valor negativo $(-2,3 \%)$ para o grupo dos básicos. Os semimanufaturados e manufaturados, embora 


\section{ÍNDICE DE PREÇOS \\ PRODUTOS DA AGROINDÚSTRIA}

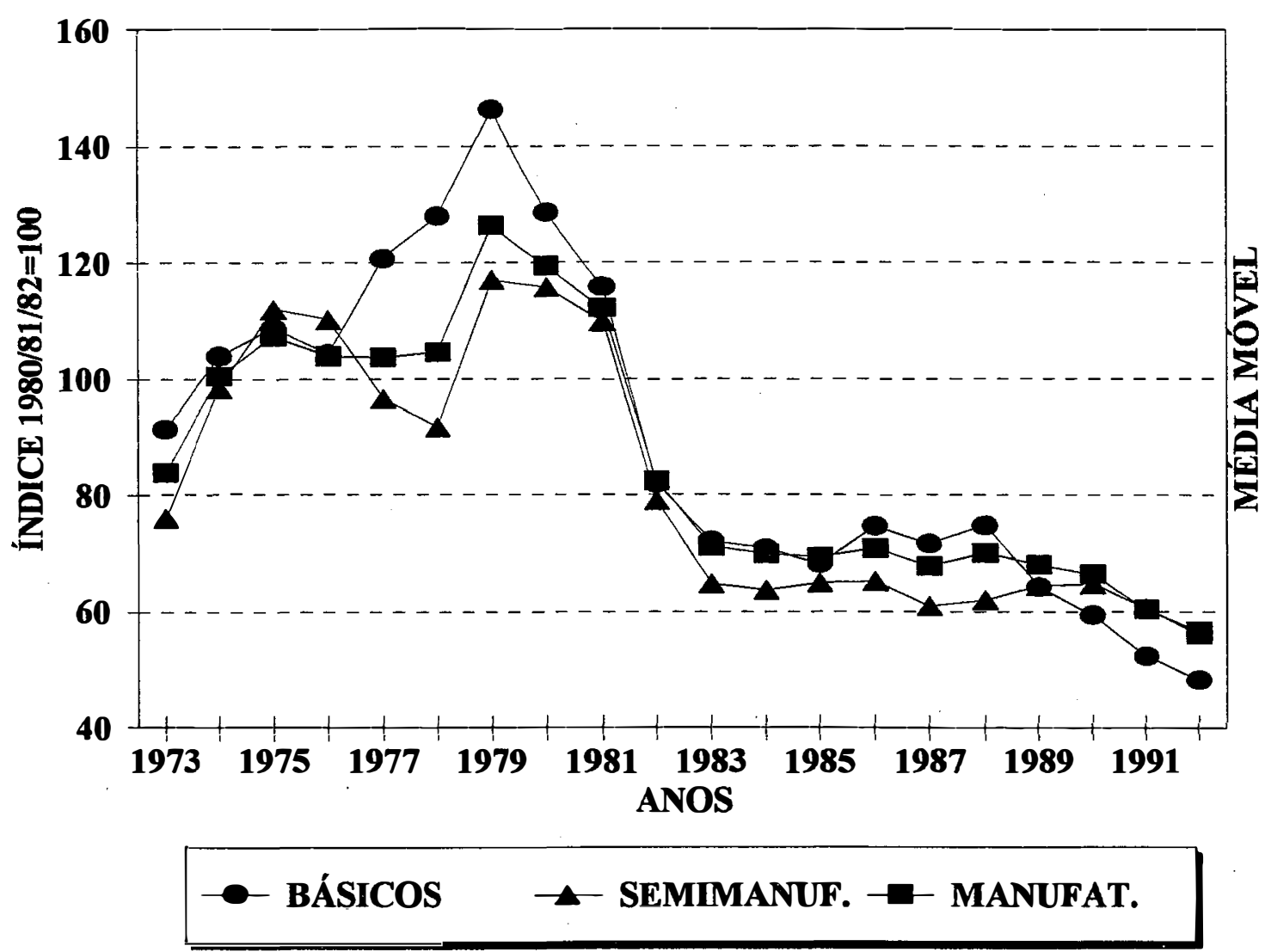

Figura 6 - Índice de preços externos dos produtos exportados pela agroindústria brasileira: básicos, semimanufaturados e manufaturados 
apresentando taxas também muito inferiores às atingidas na década de 70 , registraram crescimento de $3,8 \%$, para os primeiros e variação estatisticamente igual a zero para os segundos; nesse caso confirmando o período de estabilidade.

Subdividindo a série de dados em periodos menores foi possivel identificar divergências de comportamento ainda maiores entre os grupos. A queda da taxa de crescimento do valor das exportações de básicos, que já se manifestava de $1971 / 81$ para $1982 / 87$, acentuou-se no subperiodo mais recente de 1988/92 (-7,7\%). Os semimanufaturados apresentaram taxas de crescimento positivas em determinados subperiodos, o que também ocorreu com o grupo dos manufaturados. Em outros, as taxas calculadas não apresentaram resultados estatisticamente significativos aos niveis estabelecidos, dada a instabilidade (alternância de crescimentos e decréscimos) do valor das exportações desde meados da década de 1980.

Com relação à quantidade exportada (Figuras $3 b, 4 b$ e $5 b$ ), embora os dados mostrem sucessão de quedas e acréscimos em periodos e, ou, anos específicos, a tendência geral, ao longo do periodo, foi ascendente para os três agregados analisados.

Mesmo nos periodos em que os preços internacionais não estimulavam as exportações, a quantidade exportada manteve tendência crescente com diferenças entre os três agregados apenas quanto à intensidade de crescimento. Por exemplo, do início até meados da década de 80 , o crescimento da quantidade exportada de básicos e manufaturados foi mais acentuada que dos semimanufaturados. Ao final dos anos 80 e início dos anos 90 , os semimanufaturados passaram a crescer mais intensamente, enquanto os outros agregados passaram por fase de relativa estagnação.

Na verdade, há vários fatores que, associados ao movimento dos preços, afetaram o comportamento da quantidade exportada pelo Brasil. Há que se levar em consideração, por exemplo, a consolidação, nos anos 80 , de diversos projetos orientados para a exportação, elaborados a partir do II PND, a reversão da situação recessiva mundial desde 1984 e, ainda os diferenciais de condição de demanda interna e externa. 
$O$ inexpressivo desempenho do setor exportador brasileiro nas duas últimas décadas veio acompanhado de uma tendência de mudança na estrutura da pauta, como já mencionado, e constitui a hipótese básica desse trabalho.

As alterações que vêm ocorrendo na participação das exportações de cada grupo no total exportado facilitam a percepção e agregam mais elementos à análise desse processo de transformação em que se ampliam as vendas para o mercado externo de produtos com maior valor adicionado. Pelas Figuras 7 e 8, correspondentes à participação do valor e da quantidade exportada de cada agregado no total, pode-se confirmar essa dinâmica própria que vem moldando o comportamento das exportações brasileiras ao longo das últimas décadas. Se pela forma ainda pouco acentuada não consolidou uma estrutura definitiva, está permitindo a conformação de uma tendência em que a exportação de básicos tradicionais vai decrescendo e, gradativamente, cedendo espaço à expansão da participação de produtos com maior grau de transformação industrial.

Em termos numéricos, a Tabela 4 mostra a evolução da participação percentual dos agregados no total exportado pela agroindústria brasileira desde 1971. Percebe-se, nitidamente, a trajetória inversa seguida pelos produtos semimanufaturados e manufaturados em relação aos básicos. Enquanto os dois primeiros grupos aumentaram sua participação relativa no valor total exportado, os produtos básicos perderam posição, tanto em valor quanto em quantidade exportada. De uma participação percentual de $78,6 \%$ no periodo de $1971 / 75$, os básicos passaram a representar $57,0 \%$ do valor da pauta brasileira de exportações agroindustriais no periodo de 1988/92.

Ao contrário, os semimanufaturados e manufaturados evoluiram para um patamar superior em participação. Os primeiros passaram de $11,0 \% \mathrm{em}$ $1971 / 75$ para $15,2 \%$ em 1988/92, e os outros atingiram um percentual ainda superior, passando de $10,5 \%$ para $28,0 \%$ do valor total das exportações de produtos agroindustriais.

Em relação à quantidade exportada, os dados mostram evolução muito semelhante, o que vem comprovar essa linha de tendência de evolução da estrutura da pauta para produtos mais elaborados. 


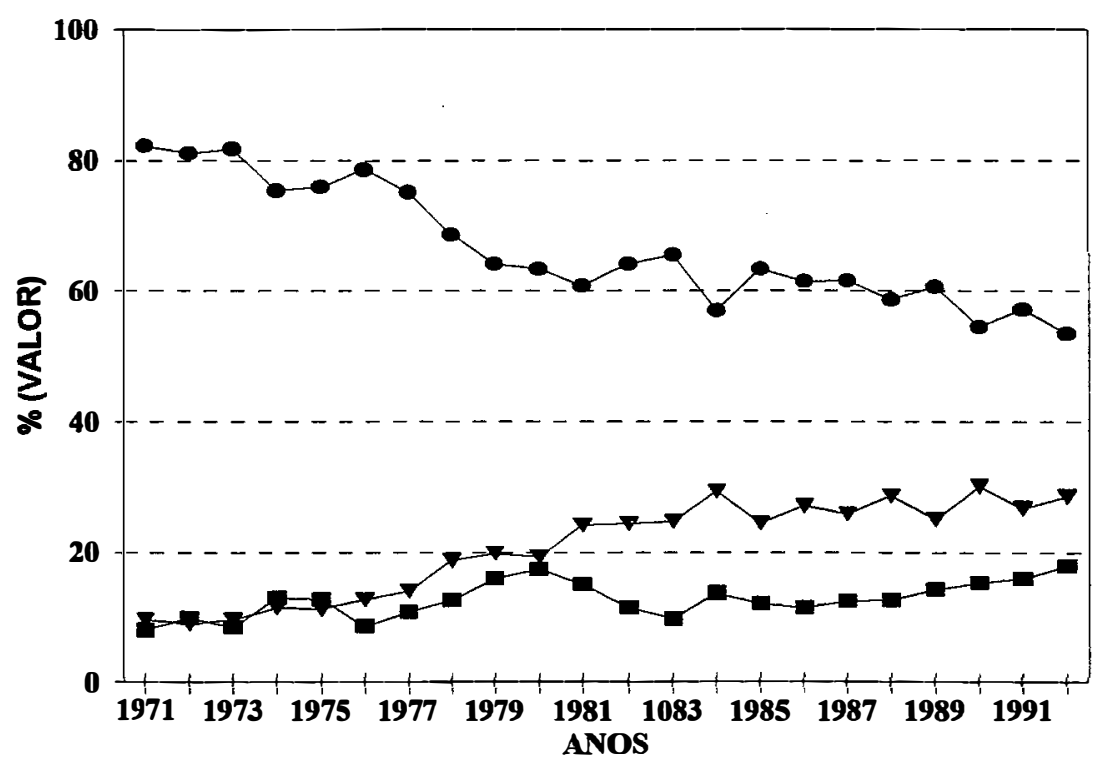

BÁSICOS $\rightarrow$ SEMIMANUF. $\rightarrow$ MANUFAT.

Figura 7 - Participação dos produtos básicos, semimanufaturados e manufafaturados no valor total exportado pela agroindústria brasileira

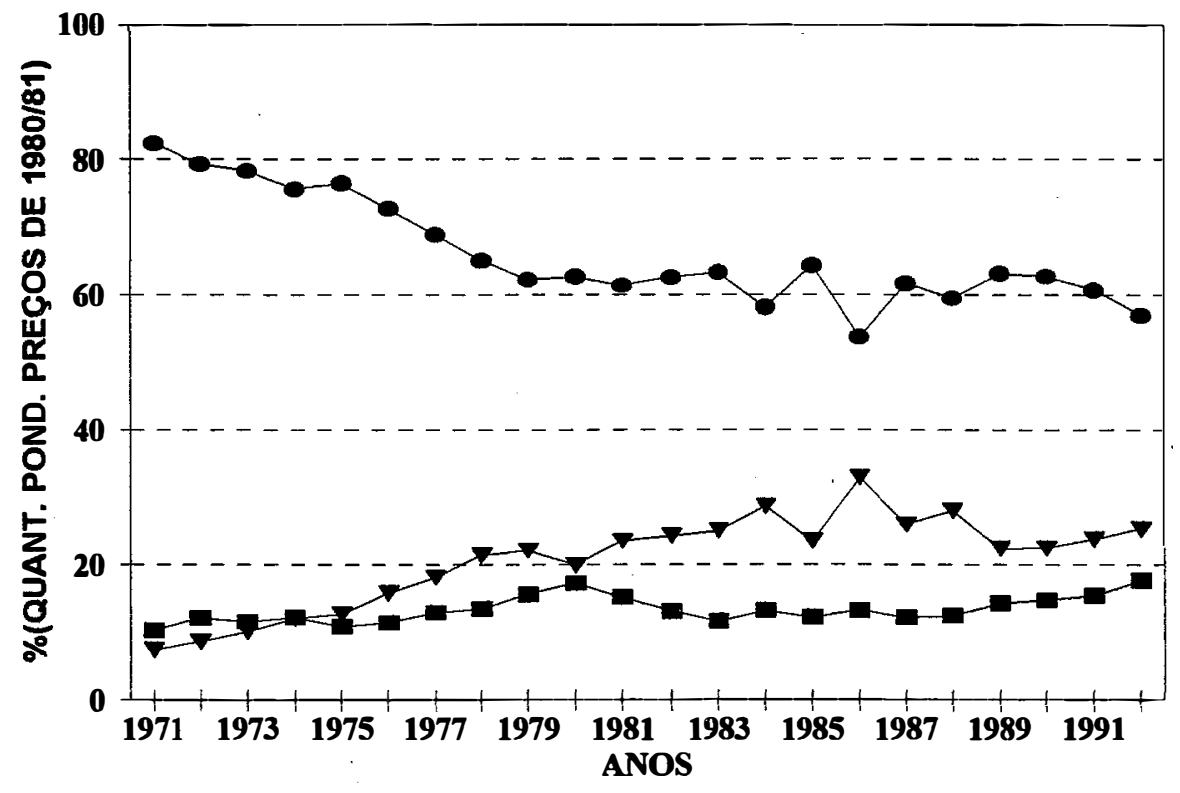

\section{BÁSICOS}

SEMIMANUF. $\rightarrow$ MANUFAT.

Figura 8 - Participação dos produtos básicos, semimanufaturados e manufaturados na quantidade total exportada pela agroindústria brasileira 
As alterações ocorridas, vistas sob a perspectiva do comportamento dos principais produtos que compõem cada grupo, se são dificultadas pela dinâmica irregular que, em alguns casos, promove mudanças anuais, possibilitam também a identificação de tendências especificas com possibilidades de se consolidarem mais rapidamente nas próximas décadas.

Uma constatação importante na análise desagregada do grupo dos básicos (Tabela 3.1 do Apêndice 3) é a expressiva perda de peso dos produtos café em grãos, açúcar demerara e algodão bruto, que, no início do periodo analisado (1971), respondiam por 55,5\%, 10,5\% e 10,0\%, respectivamente, do valor das exportações desse grupo, passaram a representar, em 1992, apenas $17,5 \%, 3,0 \%$ e $0,5 \%$ respectivamente. As taxas de crescimento estimadas para os subperíodos ${ }^{1}$ mostram a trajetória deste declíneo, que, embora persistente desde a década de 70 , teve as maiores quedas no subperíodo de 1988/92, com o café em grãos $(-16,4 \%)$, de 1982/87, com o açúcar demerara $(-17,4 \%)$, e de 1971/81, com o algodão bruto $(-34,4 \%)$.

Tabela 4 - Participação Percentual das Exportações Brasileiras por Agregado nas Exportações Brasileiras Totais da Agroindústria, em \%, no período de $1971 / 92$

\begin{tabular}{lllllll}
\hline \multirow{2}{*}{ SUBPERIODOS } & \multicolumn{2}{c}{ BÁSICOS } & \multicolumn{2}{c}{ SEMIMANUFATURADOS } & \multicolumn{2}{c}{ MANUFATURADOS } \\
\cline { 2 - 7 } & VALOR & QUANTIDADE & VALOR & QUANTIDADE & VALOR & QUANTIDADE \\
\hline $1971 / 75$ & 78,59 & 78,29 & 10,93 & 11,45 & 10,47 & 10,26 \\
$1976 / 81$ & 67,32 & 64,94 & 13,9 & 14,57 & 18,78 & 20,49 \\
$1982 / 87$ & 61,95 & 60,71 & 11,94 & 12,61 & 26,11 & 26,62 \\
$1988 / 92$ & 56,91 & 60,49 & 15,18 & 15,07 & 27,91 & 24,45 \\
\hline
\end{tabular}

O cacau cru, produto tradicionalmente importante desse grupo, embora de menor expressão relativa em termos percentuais, apresentou taxa de crescimento expressiva no período de 1971/81 (11,1\%), porém começou a perder

${ }^{1}$ Os valores referentes a cada produto analisado encontram-se no Apêndice 4. 
espaço na pauta de exportações desde o inicio dos anos 80 . Este processo tornou-se mais intenso em 1988/92, quando as exportações desse produto apresentaram a significativa taxa de decréscimo média de $-22,4 \%$.

O complexo soja aparece com importância na pauta de exportações brasileiras nos primeiros anos da década de 70 , consolidando esta posição em meados desse periodo com as exportações de grãos e farelo crescendo a taxas médias de 3,8\% e 23,0\%, respectivamente, no período de 1971/81. A partir daí, os desempenhos das exportações de farelo de soja e de soja em grão, embora semelhantes, foram bastante irregulares. Observam-se periodos de decréscimos com recuperações localizadas em anos especificos, seguidas de nova fase de queda e posterior tendência de retomada de crescimento. Dada essa irregularidade, as taxas geométricas de crescimento calculadas entre períodos não apresentaram estimativas que expressassem a tendência real, sendo, quase sempre, não-significativas. A despeito desse comportamento, o farelo de soja permaneceu como o principal produto exportado do grupo dos básicos, representando em $1992,28,6 \%$ do total.

Com participação bem inferior (14,4\% e 8,2\%), mas de grande importância dentre os básicos pela evolução gradativamente crescente de suas exportações nos últimos periodos, destacam-se o fumo em folhas e a came de frango. Esses dois produtos apresentaram taxas de crescimento altas em 1971/81, especialmente a carne de frango (16,0\% e 194,5\% respectivamente), passando por um período de decréscimo $\left(-3,60 \%\right.$ e $\left.-1,9 \%^{1}\right)$ em 1982/87 e evertendo essa situação em periodo mais recente (1988/92), quando as taxas de crescimento, embora não tenham retomado os valores atingidos nos anos 70 , tiveram crescimento positivo de $9,2 \%$ e $16,2 \%$. São taxas significativas, principalmente considerando que a grande maioria dos produtos deste grupo sofreu decréscimo em suas exportações neste último subperiodo.

Vale ainda mencionar, no grupo dos básicos, as exportações de castanha-de-caju, que, apesar da participação pouco expressiva na pauta, mantiveram taxas de crescimento positivas e relativamente altas em todo 0 período.

${ }^{1}$ Essa taxa não foi significativa nos niveis de probabilidade considerados. 
Dentre os semimanufaturados, as alterações foram freqüentes, de forma a determinar composições bastante diferenciadas em cada subperiodo (Tabela 3.2 do Apêndice 3). Na primeira metade dos anos 70, as exportações de açúcar cristal e madeira serrada ocupavam posições de destaque, representando, em média, de 1971 a 1975, 29,0\% e 30,3\% das exportações desse grupo, respectivamente. Estes produtos foram perdendo expressão e espaço para outros com maior grau de industrialização, cujas taxas de crescimento passaram a apresentar valores extremamente altos a partir de meados da década de 70 , elevando assim a média do periodo de 1971/81. São exemplos: peles e couros $(11,2 \%)$, pasta química de madeira $(34,3 \%)$ e os derivados de cacau: manteiga $(8,6 \%)$ e liquor/pasta (30,3\%). Essa tendência foi acentuando-se na década de 80 , resultando em uma estrutura da pauta diferente da observada nos anos 70 , no sentido da diversificação em produtos mais elaborados.

As exportações de madeira serrada, após acentuado decréscimo nos primeiros anos da década de 70 , passaram a ter um comportamento estável nos anos 80 , embora em patamar extremamente inferior. $O$ que sustentou a posição de destaque do complexo madeira entre os semimanufaturados foi a manutenção das exportações de pasta química a taxas médias crescentes em todo o periodo, embora com diferenças na magnitude dos valores entre os subperiodos. Esse produto passou a representar, no início dos anos 90 , em tomo de $40,0 \%$ do total de semimanufaturados exportados.

Em proporção menor que no periodo anterior, mas com taxas ainda crescentes, permaneceram as exportações dos derivados de cacau, manteiga e liquor/pasta, em 1982/87 (10,4\% e 1,9\% respectivamente). A partir dai, estas exportações entraram em uma fase de nítido decréscimo, acompanhando o expressivo retrocesso das exportações brasileiras do complexo cacau.

Em sintese, no grupo dos semimanufaturados os produtos mais dinâmicos da pauta foram os de maior valor agregado como a pasta química de madeira e os subprodutos da pecuária, peles e couros, que mantiveram taxas de crescimento altas e positivas no periodo como um todo e entre os subperiodos, embora em alguns casos, não tenham atingido os niveis de significância estatística considerados. Juntos, estes produtos representaram, em $1992,60,4 \%$ do total das 
exportações de semimanufaturados, sendo $39,6 \%$ correspondentes a pasta química e $20,8 \%$ a peles e couros.

Finalmente, dentre os manufaturados (Tabela 3.3 do Apêndice 3), o conjunto de produtos que lideravam as exportações com altas taxas de crescimento na década de 70 (café solúvel: 12,0\%, carne bovina industrializada: $8,2 \%$, açúcar refinado: $72,6 \%$, fios de algodão: $21,3 \%$ e tecidos - $10,9 \%$ ) sofreu queda de valor exportado na década seguinte e teve taxas de crescimento negativas em 1982/92, com exceção das exportações de tecidos de algodão, cuja taxa decresceu, mas não chegou a apresentar valor negativo. Esse conjunto de produtos que representava em média $77,0 \%$ das exportações brasileiras de manufaturados agroindustriais em 1974/76 teve sua participação diminuida para $35,0 \%$ em 1992.

Nesse grupo, é importante ainda identificar alguns produtos cuja análise, em períodos menores, mostra diferenças de comportamento. A carne industrializada, o açúcar refinado e os tecidos apresentaram, de 1982/87 para 1988/92, taxas crescentes indicando uma tendência de retomada de crescimento. Outros, como café industrializado, fios de algodão e óleo refinado de soja, não só permaneceram com taxas de crescimento negativas, como tiveram as magnitudes dessas taxas bastante elevadas. Quanto ao óleo refinado de soja, faz-se uma ressalva, pois nos anos especificos de 1991 e 1992 suas exportações voltaram a crescer, o que ficou encoberto pelas fortes quedas ocorridas em 1988 e 1989.

O suco de laranja concentrado congelado lidera as exportações de produtos manufaturados. Sua participação na pauta vem ampliando-se crescendo desde a década de 70 , tendo, neste periodo, crescido a uma taxa média de $22,9 \%$. Essa tendência foi mantida ao longo da década de 80 , apesar dos decréscimos anuais localizados. Os anos 90 têm mostrado, no entanto, um retrocesso nas suas exportações explicado por fenômenos conjunturais, o que não se deve transformar em tendência permanente. Quanto à participação percentual, só as exportações de suco de laranja representaram, em 1990/92, 40,0\% do total de produtos manufaturados exportados.

As exportações de papel surgiram com grande vigor no final dos anos 70 e expandiram-se na década de 80 e inicio de 90 a uma taxa média de $14,0 \%$ a.a., dividindo a liderança das exportações de manufaturados com o suco 
de laranja. Juntos, passaram a representar, nos anos mais recentes (1990/92), $65,0 \%$ das exportações desse grupo, importância mantida na pauta brasileira de exportações totais da agroindústria, na qual o suco de laranja disputa com o café em grãos o segundo lugar (café: $11,7 \%$, e suco de laranja: 11,6\%). O papel ocupa o quarto lugar com uma participação de $7.1 \%$, sendo pequena a diferença em relação ao percentual da soja em grãos $(7,3 \%)$, que, neste periodo, foi o terceiro produto exportado. $O$ farelo de soja figura como o mais importante produto exportado pela agroindústria brasileira.

Em linhas gerais, a análise desagregada mostra a perda de peso, na pauta de exportações agroindustriais brasileiras, dos complexos café, açúcar, algodão e cacau. Este fenômeno, embora ocorra de forma mais acentuada entre os produtos brutos, é observado também para outros com algum grau de industrialização, como café solúvel, açúcar cristal e fios de algodão. Ainda com relação a esses complexos tradicionalmente exportados, os subprodutos açúcar refinado e tecidos apresentaram também taxas de crescimento negativas porém com tendência de retomada de crescimento no último periodo (1988/92).

As alterações ocorridas na estrutrura da pauta de exportações da agroindústria brasileira são confirmadas na medida em que tomam-se mais importantes, dentro de cada grupo, produtos que antes não faziam parte da relação de exportados ou não tinham maior expressão. Assim, dentro dos básicos, o farelo de soja permanece na liderança, apesar da tendência declinante dos últimos anos, vindo em seguida, com menor importância relativa, mas com evolução crescente, o fumo em folhas, a carne de frango e a castanha-de-caju.

No grupo dos semimanufaturados, lideram as exportações, a pasta química de madeira, representando $40,0 \%$ do total exportado, e peles e couros com $20,8 \%$.

As exportações de suco de laranja representam o maior percentual do total de manufaturados exportados $(40,0 \%)$ e vem ampliando sua participação na pauta, assim como o papel que já responde por $25,0 \%$.

Considerando o total exportado pela agroindústria brasileira, podese perceber a presença de produtos com maior grau de industrialização ao lado dos exportáveis tradicionais: farelo de soja $(15,5 \%)$, café em grão $(11,7 \%)$, suco 
de laranja $(11,0 \%)$, soja em grãos $(7,3 \%)$, papel $(7,0 \%)$ e pasta quimica de madeira $(6,5 \%)$. 


\section{EVOLUÇÃO DA ESTRUTURA DA PAUTA DO SETOR AGROEXPORTADOR NO MERCADO INTERNACIONAL}

\subsection{INTRODUÇÃO}

O comércio mundial de produtos agrícolas passou por mudanças significativas nas últimas décadas. Desde os anos 60 , impulsionado por preços internacionais estáveis, o intercâmbio comercial agricola mundial apresentou comportamento de expansão, que permaneceu até os primeiros anos da década de 70. Com a queda no ritmo de crescimento da economia mundial, decorrente da diminuição da demanda, da crise do petróleo, dos preços altos dos alimentos no mercado externo, entre outros, ocorreram senão uma inversão de tendência, pelo menos, um arrefecimento do ritmo de expansão do comércio mundial agricola e uma situação econômica instável e em processo de mudança.

Ao final dos anos 70 e no inicio de 80 , já se confirmavam plenamente tendências delineadas desde meados da década de 70: os principais paises desenvolvidos, antes importadores líquidos de produtos agricolas, passaram à posição de auto-suficientes e exportadores de excedentes, pelos estimulos à produção e aos investimentos recebidos no setor como parte das politicas adotadas para enfrentarem as adversidades externas.

$O$ efeito dos subsidios concedidos e do protecionismo ao setor agricola foi de substancial relevância para o crescimento dos estoques finais. Isso, se por um lado, trouxe, de início, queda nos preços e, posteriormente, certa normalização dos fluxos do comércio, por outro estimulou, na década de 80 , uma concorrência agressiva entre os grandes paises exportadores pela conquista de maiores parcelas do mercado. 
Neste capitulo, são analisadas as tendências observadas no mercado externo de produtos agroindustriais, considerando os principais mercados continentais, países e, ou, blocos econômicos ${ }^{1}$, importantes para o entendimento da dinâmica do comércio mundial nas últimas décadas.

A análise da estrutura da pauta é feita considerando os agregados básicos, semimanufaturados e manufaturados, à semelhança do procedimento adotado para o Brasil. Pretendeu-se, dessa forma, identificar a ocorrência do redirecionamento da pauta de exportações para um ou outro agregado especifico, ou seja, verificar o comportamento da estrutura da pauta de exportação entre os principais exportadores mundiais de produtos da agroindústria. A questão central é fazer uma análise comparativa entre o que está ocorrendo no mundo e o observado no Brasil, com o propósito de caracterizar o fenômeno como uma tendência geral ou um padrão de comportamento especifico e localizado.

Dado o grande número de complexos agroindustriais ${ }^{2}$, a análise por produto considera, inicialmente, os agrupamentos: grãos oleaginosos, óleos, farelos/tortas e cereais. O comportamento de cada produto, em especial, dentro desses grupos, é qualificado quando sua importância for determinante na evolução e na tendência do grupo. Os demais, que não sè enquadram nessas definições, são analisados separadamente.

Os dados utilizados na análise evolutiva referem-se a quatro periodos representados por médias de três anos: 1973/74/75 (período1), 1977/78/79 (período 2), 1982/83/84 (periodo 3), e 1989/90/91 (periodo 4), deflacionados $^{3}$ e expressos em dólar de 1992. Os gráficos mostram a evolução das exportações nos principais mercados continentais e, ou, paises, de acordo com sua importância no grupo do produto analisado, e também as tendências nos três blocos econômicos: NAFTA (North American Free Trade Agreement), UE (União Européia) e MERCOSUL (Mercado Comum do Cone Sul). As taxas geométricas médias de crescimento complementam a análise, na medida em que quantificam a proporção e o ritmo das mudanças ocorridas.

\footnotetext{
${ }^{1}$ A relação desses mercados encontra-se no Apêndice 5.

${ }^{2}$ Os complexos agroindustriais e a relação dos produtos que compõem cada agrupamento constam do Apêndice 6.

${ }^{3}$ Foi utilizado como deflator o Índice de Preços no Atacado, nos EUA.
} 


\subsection{TENDÊNCIAS DAS EXPORTAÇÕES POR AGREGADOS BÁSICOS, SEMIMANUFATURADOS E MANUFATURADOS}

\section{Básicos}

Do total comercializado pela agroindústria no mercado mundial, as exportações de produtos básicos representam 45,0\%. Considerando as exportações em cada mercado continental, verifica-se que Oceania, África e América Latina são, hoje, os principais exportadores de produtos agroindustriais básicos, sendo os percentuais que estes representam, em relação ao total exportado, em cada caso, $80,7 \%$; $76,7 \%$; e $57,0 \%$, respectivamente (Tabela $5 a$ ).

Analisando a evolução desta participação ao longo do tempo, constata-se uma tendência de queda em todos esses mercados, mas, em relação à proporção dos decréscimos, os valores correspondentes à América Latina são significativamente superiores aos dos outros dois. Enquanto na Oceania e África o decréscimo médio, entre os periodos, variou de 3,0\% a 6,0\%, na América Latina foi em média $12,0 \%$ e, no Brasil, 10,0\%. Esse resultado está refletindo quedas específicas nas exportações de alguns produtos como açúcar bruto, algodão bruto, cacau em grão, café em grão, que têm pesos relativamente altos na composição das exportações do grupo de básicos.

Entre os blocos econômicos, este fenômeno também se confirmou. A queda ocorrida no MERCOSUL foi bem superior à observada nos demais blocos e se deu ao longo do período, persistindo desde meados da década de 70. Este comportamento, que ocorre também no Brasil, está certamente influenciando a evolução da estrutura da pauta de exportações do MERCOSUL.

Nos demais blocos exportadores, a tendência geral de evolução da proporção de produtos básicos na pauta de exportações é de estabilidade, apesar da ocorrência de decréscimos localizados.

Considerando especificamente, o total de básicos comercializados no mundo (Tabela 6 e Figura 9), as exportações estão concentradas no mercado 
Tabela 6 - Exportaçōes mundiais de produtos básicos, semimanufaturados e manufaturados, em 1000 US\$ FOB de 1992 , e participagajo percentual de cada agregado no total exportado pela agroindústria

\begin{tabular}{|c|c|c|c|c|c|c|c|c|}
\hline REGIAO/PAS & $1973 \sqrt{7475}$ & $1977 \pi 8 / 79$ & $1982 / 83 / 84$ & $1989 / 90 / 91$ & $\%$ & $\%$ & $\%$ & $\overline{\%}$ \\
\hline $\begin{array}{l}\text { MUNDO } \\
\text { EUROPA } \\
\text { ÁSIA }\end{array}$ & $\begin{array}{r}130711414 \\
26647606 \\
13713466\end{array}$ & $\begin{array}{r}160026637 \\
34016004 \\
16676087\end{array}$ & $\begin{array}{r}113818826 \\
25808608 \\
10684896\end{array}$ & $\begin{array}{r}117700647 \\
40166637 \\
13043479\end{array}$ & $\begin{array}{l}69.69 \\
33.77 \\
69.46\end{array}$ & $\begin{array}{l}67.67 \\
34.24 \\
62.21\end{array}$ & $\begin{array}{l}66.36 \\
36.16 \\
47.66\end{array}$ & $\begin{array}{l}46.04 \\
33.81 \\
38.08\end{array}$ \\
\hline $\begin{array}{l}\text { AMÉRICA LATINA } \\
\text { ÁFRICA }\end{array}$ & $\begin{array}{l}26293124 \\
12144416\end{array}$ & $\begin{array}{l}33188726 \\
16939120\end{array}$ & $\begin{array}{r}21773444 \\
8066163\end{array}$ & $\begin{array}{r}17037926 \\
7366728\end{array}$ & $\begin{array}{l}82.99 \\
86.76\end{array}$ & $\begin{array}{l}74.29 \\
85.81\end{array}$ & $\begin{array}{l}66.86 \\
83.36\end{array}$ & $\begin{array}{l}67.02 \\
76.73\end{array}$ \\
\hline $\begin{array}{l}\text { OCEANIA } \\
\text { UE } \\
\text { NAFTA } \\
\text { EFTA }\end{array}$ & $\begin{array}{r}8204654 \\
.19799181 \\
43916675 \\
2134288\end{array}$ & $\begin{array}{r}9272832 \\
27444094 \\
49763102 \\
2389284\end{array}$ & $\begin{array}{r}7037264 \\
21326169 \\
39149834 \\
1628437\end{array}$ & $\begin{array}{r}7980678 \\
36168907 \\
31647077 \\
2476096\end{array}$ & $\begin{array}{l}88.26 \\
38.66 \\
68.16 \\
12.03\end{array}$ & $\begin{array}{l}87.63 \\
38.60 \\
68.14 \\
11.80\end{array}$ & $\begin{array}{l}83.14 \\
39.41 \\
67.76 \\
11.81\end{array}$ & $\begin{array}{l}80.74 \\
39.07 \\
63.94 \\
10.05\end{array}$ \\
\hline $\begin{array}{l}\text { MERCOSUL } \\
\text { "TIGRES ASIÁTICOS" } \\
\text { ORIENTE MÉDIO }\end{array}$ & $\begin{array}{r}11323733 \\
1867662 \\
2074139 \\
\end{array}$ & $\begin{array}{r}13121336 \\
2713714 \\
2262800 \\
\end{array}$ & $\begin{array}{l}9812237 \\
1683662 \\
1498716 \\
\end{array}$ & $\begin{array}{l}7778197 \\
1866633 \\
1688166 \\
\end{array}$ & $\begin{array}{l}\cdot 76.77 \\
26.37 \\
79.96 \\
\end{array}$ & $\begin{array}{l}69.30 \\
27.46 \\
78.87 \\
\end{array}$ & $\begin{array}{l}61.07 \\
20.68 \\
62.62 \\
\end{array}$ & $\begin{array}{l}41.48 \\
16.76 \\
68.38 \\
\end{array}$ \\
\hline
\end{tabular}

(a)

\begin{tabular}{|c|c|c|c|c|c|c|c|c|}
\hline REGIATOIPAIS & $1973 / 74 \sqrt{76}$ & $1 9 7 7 \longdiv { 7 8 7 9 }$ & $1982 / 83 / 84$ & $1989 / 90 / 91$ & $\%$ & $\%$ & $\%$ & $\%$ \\
\hline $\begin{array}{l}\text { MUNDO } \\
\text { EUROPA } \\
\text { ÁSLA }\end{array}$ & $\begin{array}{r}27079677 \\
11690861 \\
1473619\end{array}$ & $\begin{array}{r}40886466 \\
17014661 \\
6372862\end{array}$ & $\begin{array}{r}31419999 \\
12421162 \\
3286068\end{array}$ & $\begin{array}{r}46431860 \\
18062076 \\
7010314\end{array}$ & $\begin{array}{r}12.36 \\
16.32 \\
6.39\end{array}$ & $\begin{array}{l}14.73 \\
17.13 \\
18.01\end{array}$ & $\begin{array}{l}16.28 \\
16.85 \\
14.66\end{array}$ & $\begin{array}{l}17.77 \\
16.21 \\
20.47\end{array}$ \\
\hline AMÉRICA LATINA & 2259662 & 6998222 & 6473602 & 6726639 & 7.41 & 13.43 & 16.81 & 22.61 \\
\hline ÁFRICA & 772238 & 1143291 & 683707 & 929929 & 6.62 & 6.16 & 7.08 & 9.69 \\
\hline OCEANIA & 179639 & 382927 & 606003 & 627929 & 1.93 & 3.61 & 6.98 & 6.34 \\
\hline UE & 6979693 & 10462090 & 8227980 & 12606169 & 11.65 & 14.66 & 16.21 & 13.90 \\
\hline NAFTA & 10173677 & 11884912 & 9196627 & 13144654 & 16.79 & 16.27 & 16.92 & 22.40 \\
\hline EFTA & 4966423 & 6676473 & 2787110 & 6128146 & 27.94 & 27.63 & 20.21 & 20.81 \\
\hline MERCOSUL - TOTAL & 1886686 & 6041658 & 4998464 & 6062473 & 12.62 & 22.78 & 26.02 & 32.28 \\
\hline "TIGRES ASIATICOS" & 639367 & 1721647 & 836090 & 1370791 & 7.33 & 17.42 & 10.87 & 11.63 \\
\hline ORIENTE MÉDIO & 101469 & 66797 & 66044 & 184463 & 3.91 & 1.98 & 2.34 & 6.87 \\
\hline
\end{tabular}

(b)

\begin{tabular}{|c|c|c|c|c|c|c|c|c|}
\hline EबाA & 19737476 & 1977 & 3184 & & & & & \\
\hline MUNDO & 61661367 & 76676072 & 367 & 97176869 & 28.07 & 27.60 & 29.37 & $\frac{10}{37.19}$ \\
\hline EUROPA & 38607117 & 48316281 & $\$ 37$ & 60649829 & 60.90 & 48.63 & 48.00 & 60.98 \\
\hline ÁSIA & 7877668 & 8884487 & 668 & 14200086 & 34.16 & 29.78 & 37.69 & 41.46 \\
\hline AMÉRICA LATINA & 2924842 & 6486476 & $632 v 365$ & 5230 & 9.60 & 12.28 & 16.34 & 20.47 \\
\hline FRICA & 1081749 & 1493111 & 924809 & 1304695 & 7.73 & 8.04 & 9.67 & 13.69 \\
\hline OCEANIA & 912696 & 938087 & 920962 & 1376918 & 9.82 & 8.85 & 10.88 & 13.92 \\
\hline UE & 26669470 & 33394003 & 24669066 & 4233 & 49.80 & 46.84 & 46.39 & 47.04 \\
\hline NAFTA & 10349466 & 11386464 & 9436743 & 13878977 & 16.06 & 16.69 & 16.33 & 23.66 \\
\hline EFTA & 10650808 & 12285683 & 9376896 & 17040877 & 60.03 & 60.67 & 67.99 & 69.16 \\
\hline ER & 122 & 39 & 4402231 & 4921965 & 11.60 & 17.92 & 22.91 & 26.26 \\
\hline TIG & 4963602 & 664 & 6274193 & 639 & 67.30 & 65.13 & 68.65 & 72.61 \\
\hline ORIENTE MÉDIO & 418231 & 649277 & 838673 & 933422 & 16.12 & 19.16 & 35.04 & 34.75 \\
\hline
\end{tabular}

Fonte: FAO/NAÇŌES UNIDAS.

(c) 
Tabela 6 - Exportações mundiais de produtos básicos (1000 US\$ FOB de 1992) - taxas geométricas médias anuais de crescimento

\begin{tabular}{|c|c|c|c|c|c|c|c|}
\hline REGIAO/PAIS & $1 9 7 3 \longdiv { 7 4 7 6 }$ & $1 9 7 7 \longdiv { 7 8 / 7 9 }$ & $1982 / 83 / 84$ & $1989 / 90 / 91$ & $\%$ & $\%$ & $\%$ \\
\hline & a & $b$ & $c$ & d & $\mathbf{b} / \mathbf{a}$ & $\mathbf{c} / \mathbf{b}$ & d/c \\
\hline MUNDO & 130711414 & 160026637 & 113818826 & 117700647 & 6.19 & -6.69 & 0.48 \\
\hline EUROPA & 26647606 & 34016004 & 25908608 & 40166637 & 7.42 & -6.30 & 6.46 \\
\hline UE & 19799181 & 27444094 & 21326169 & 35158907 & 8.61 & -4.92 & 7.40 \\
\hline NAFTA & 43916676 & 49763102 & 39149834 & 31647077 & 3.17 & -4.68 & -2.99 \\
\hline Estados Unidos & 36441187 & 41066928 & 31186264 & 25036801 & 3.76 & -6.35 & -3.09 \\
\hline AMÉRICA LATINA & 26293124 & 33188726 & 21773444 & 17037925 & 7.03 & -8.08 & -3.44 \\
\hline ÁSIA & 13713466 & 16676087 & 10684896 & 13043479 & 3.24 & -7.26 & 2.89 \\
\hline França & 6166978 & 7031478 & 6666419 & 10109696 & 3.34 & -1.36 & 6.36 \\
\hline OCEANIA & 8204654 & 9272832 & 7037264 & 7980678 & 3.11 & -6.37 & 1.81 \\
\hline MERCOSUL & 11323733 & 13121336 & 9812237 & 7778197 & 3.76 & -6.65 & -3.26 \\
\hline AFRICA & 12144416 & 16939120 & 8065163 & 7366728 & 7.03 & -12.76 & -1.27 \\
\hline Canadá & 6847636 & 6878813 & 7194200 & 6874607 & 0.11 & 0.90 & -2.86 \\
\hline Holanda & 4337189 & 6617344 & 3283041 & 6537802 & 6.20 & -9.86 & 7.76 \\
\hline Austrália & 6998961 & 6664866 & 6087178 & 6383146 & 2.24 & -4.94 & 0.81 \\
\hline Alemanha & 1627662 & 3174704 & 2626492 & 4630947 & 18.18 & -3.72 & 8.10 \\
\hline Brasil & 7262676 & 7140854 & 6000470 & 3868628 & -0.39 & -6.88 & -3.60 \\
\hline Dinamarca & 2039460 & 3060993 & 2168293 & 3618960 & 10.68 & -6.66 & 7.69 \\
\hline China & 4662 & 1863380 & 1427146 & 2838866 & -10.66 & -5.09 & 10.32 \\
\hline Argentina & 3644263 & 6368206 & 4163371 & 2747863 & 10.17 & -6.00 & -6.73 \\
\hline Reino Unido & 1002262 & 2214903 & 1946005 & 2665198 & 21.93 & -2.66 & 4.60 \\
\hline Bol-Lux & 1613668 & 2264497 & 1814837 & 2602680 & 10.60 & -4.33 & 6.29 \\
\hline Tailândia & 6206712 & 2490782 & 3647 & 2903 & -16.83 & -1.98 & 2.02 \\
\hline EFTA & 2134288 & 2389284 & 1628437 & 2476095 & 2.86 & -7.38 & 6.17 \\
\hline Espanha & 1067198 & 1264949 & 823294 & 2274216 & 4.34 & -8.23 & 16.62 \\
\hline "TIGRES ASIÁTICC & 1867662 & 2713714 & 1683662 & 1866633 & 9.79 & -10.21 & 2.30 \\
\hline ORIENTE MÉDIO & 2074139 & 2262800 & 1498716 & 1668166 & 2.20 & -7.91 & 0.66 \\
\hline URSS (formal) & 3361761 & 3323365 & 1863034 & 1346443 & -0.21 & -10.93 & -4.63 \\
\hline Irlanda & 972936 & 1631310 & 820905 & 1300672 & 12.01 & -11.72 & 6.80 \\
\hline Itália & 629041 & 823077 & 743816 & 1136676 & 6.95 & -2.00 & 6.23 \\
\hline Grécia & 718228 & 788612 & 671920 & 1091647 & 2.36 & -6.22 & 9.67 \\
\hline Noruega & 766861 & 765196 & 404479 & 1040742 & -0.06 & -11.97 & 14.46 \\
\hline Coréia do Sul & 709767 & 1402626 & 614014 & 877183 & 18.67 & -16.23 & 6.23 \\
\hline Paraguai & 149470 & 324693 & 267888 & 736880 & 21.40 & -4.60 & 16.18 \\
\hline México & 1626949 & 1827361 & 769370 & 735669 & 2.95 & -16.89 & -0.64 \\
\hline Islândia & 495638 & 642660 & 331606 & 628279 & 6.71 & -12.40 & 9.66 \\
\hline Uruguai & 296604 & 309335 & 412871 & 448227 & 1.06 & 6.94 & 1.18 \\
\hline Áustria & 60418 & 166969 & 240840 & 386937 & 26.96 & 8.94 & 7.01 \\
\hline Hong Kong & 243143 & 302437 & 162183 & 366896 & 6.61 & -12.83 & 13.36 \\
\hline Japăo & 667632 & 616688 & 307354 & 310976 & -6.86 & -9.86 & 0.17 \\
\hline Cingapura & 267120 & 474407 & 610011 & 302680 & 16.65 & 1.46 & -7.19 \\
\hline Suécia & 640361 & 464303 & 423624 & 293680 & -4.24 & -1.39 & -6.10 \\
\hline Portugal & 3816 & 1284 & 20200 & 136460 & -23.84 & 73.63 & 31.38 \\
\hline Finlândia & 44247 & 101662 & 98265 & 82969 & 23.09 & -0.66 & -2.39 \\
\hline 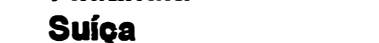 & 60024 & 60910 & 61097 & 61804 & 0.37 & -3.46 & 2.76 \\
\hline
\end{tabular}

Fonte: FAO.

Obs: Os dados estão ordenados segundos a importância do mercado exportador, com base no periodo 1989/90/91. 


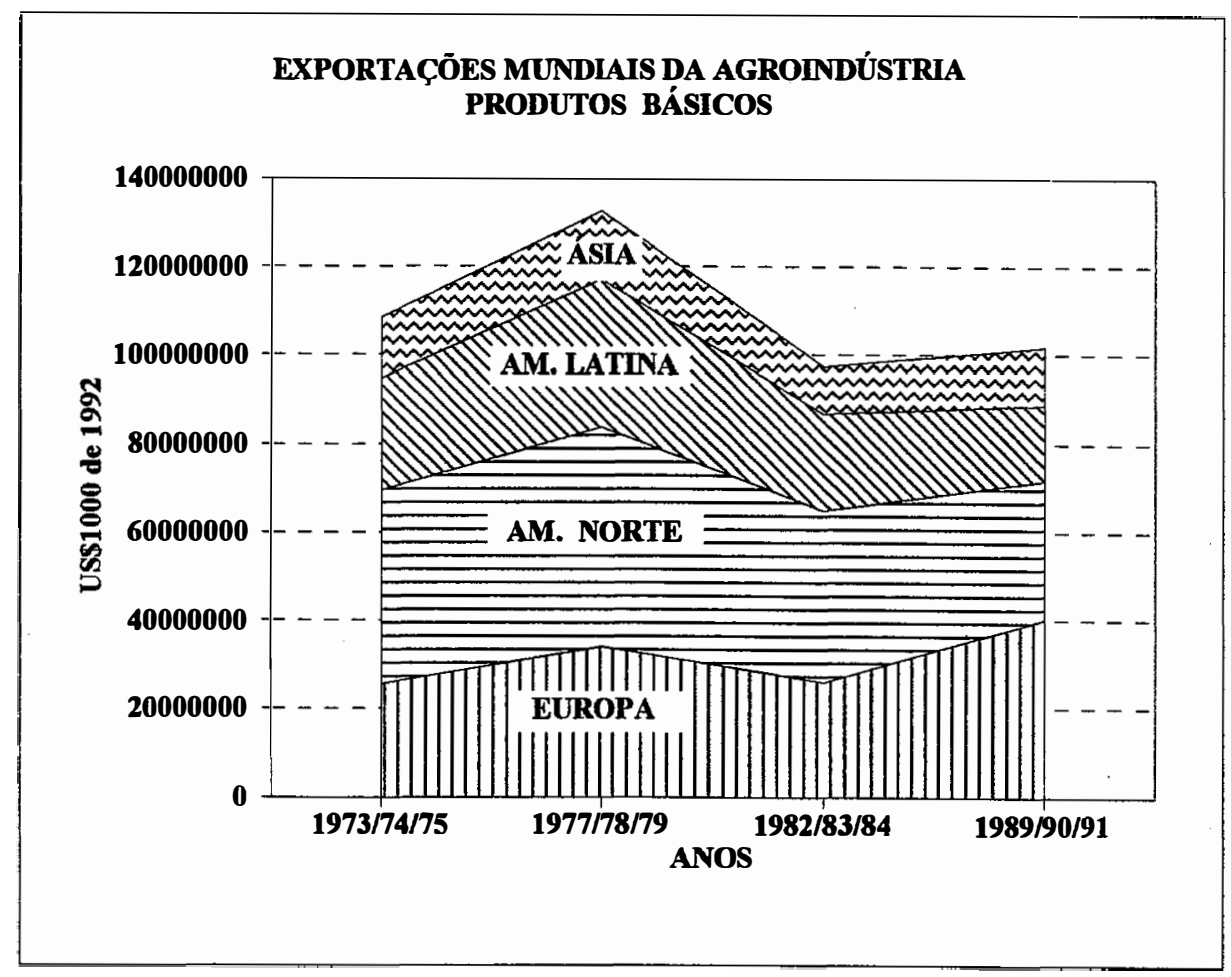

(a)

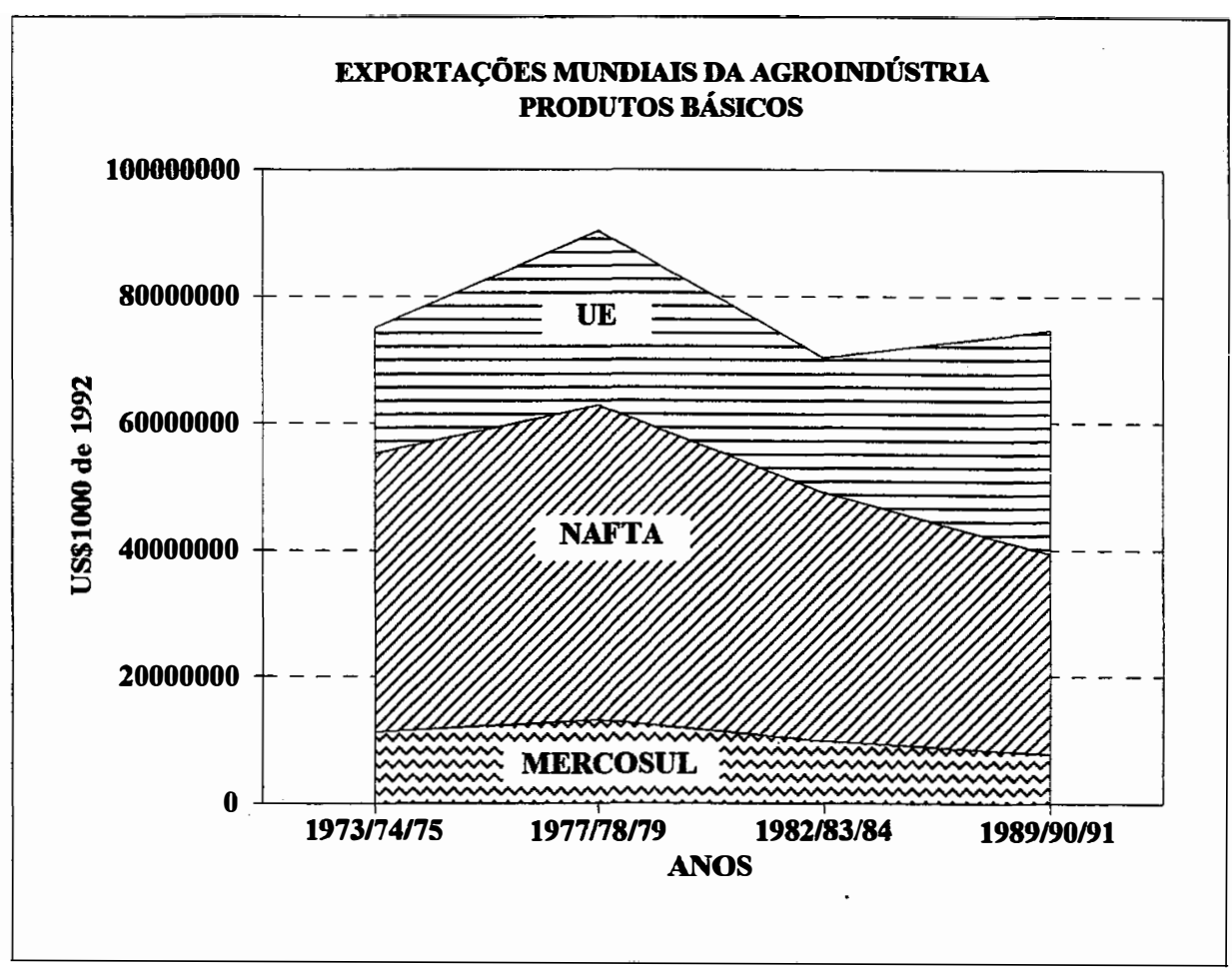

(b)

Figura 9 - Produtos básicos - ovolução das exportaçõos mundiais das principais regiöes (a) e blocos económicos (b) 
europeu $(34,1 \%)$ com a UE representando $87,5 \%$; no mercado norte-americano $(27,0 \%)$, com $79,0 \%$ provenientes dos EUA, e no mercado latino americano (14,5\%), com o Brasil representando $23,0 \%$.

As taxas geométricas de crescimento revelam que a evolução das exportações de básicos no mercado europeu foi crescente entre os períodos analisados, só ocorrendo decréscimo no periodo recessivo da economia mundial, sendo que o mesmo ocorreu em relação à UE. No mercado norte americano e na América Latina, as taxas geométricas de crescimento tiveram o seguinte comportamento: foram positivas na década de 70 , decresceram no periodo recessivo e mantiveram o decréscimo no último periodo, embora em menor proporção. Especificamente nos Estados Unidos e nos paises da UE, o crescimento das exportações de básicos durante a década de 70 foi determinado principalmente pelas politicas de apoio à produção de grãos.

A diferença de comportamento que se observa nos dados do Brasil são as taxas geométricas de crescimento sempre negativas, desde meados da década de 70 , e, basicamente em todos os periodos, superiores aos valores observados nos mercados citados. Isso demonstra que houve perda de espaço dos produtos tradicionalmente exportados, como alguns cereais e oleaginosas, como será visto nas análises especificas. São sintomas de mudança e redirecionamento da pauta de exportações brasileiras, isto é, os produtos básicos foram gradativamente cedendo espaço aos produtos agroprocessados, classificados como semimanufaturados e manufaturados. Ainda que esta não seja uma situação especifica do Brasil, mas, também, de outros mercados, os dados revelam um processo que vem ocorrendo com maior intensidade no mercado exportador brasileiro.

\section{Somimanufaturados}

Dos três agregados de produtos exportados pela agroindústria, os semimanufaturados representam a menor proporção $(17.8 \%)$ do total comercializado no mundo. Da participação destes produtos no total exportado em mercados continentais especificos, identificam-se a América Latina (22,5\%), o 
mercado norte-americano $(22,4 \%)$, a Ásia $(20,5 \%)$ e a Europa $(15,2 \%)$ com as maiores proporções (Tabela 5b).

No Brasil, $15,2 \%$ do total exportado pela agroindústria são produtos classificados como semimanufaturados. A análise da evolução das exportações desse agregado revela tendências importantes. Ao longo do periodo analisado, as exportações de semimanufaturados da América Latina foram sempre crescentes e em grandes proporções, o mesmo ocorrendo no MERCOSUL. Para o Brasil, observou-se uma tendência geral também crescente, que se interrompeu, ou seja, decresceu apenas no periodo recessivo. $O$ que explica a melhor performance das exportações de semimanufaturados na América Latina é, além da expansão de alguns mercados de tortas e óleos, o extraordinário crescimento das exportações de pasta quimica de madeira pelo Brasil, o que, certamente, teve peso considerável na evolução das exportações de semimanufaturados no mercado latino-americano e no MERCOSUL.

O mercado asiático apresentou comportamento semelhante, ou seja, tendência de maior dinamismo das exportações de semimanufaturados, exceto no período recessivo. Devem-se destacar como principais produtos desse grupo em expansão, no mercado exportador asiático, alguns tipos de tortas (de algodão e colza) e de peles e couros.

Após o periodo de crescimento das exportações de semimanufaturados no mercado europeu, durante a década de 70 , o percentual de participação desse agregado no total exportado pela agroindústria vem sofrendo gradativos decréscimos.

No mercado norte-americano observou-se uma relativa estagnação, com crescimento das exportações de semimanufaturados apenas do final da década de 80 até o início de 90 , quando ampliaram-se as exportações americanas de pasta quimica de madeira, que têm peso significativo na composição desse agregado, entre as de outros produtos menos importantes. Deve-se considerar, neste periodo, a desvalorização do dólar, que trouxe como consequência maior competitividade das exportações norte-americanas $e$, ainda, 0 fato de que 0 comportamento crescente das exportações de semimanufaturados, na década de 80, sobretudo a partir de 1985, ocorreu em termos gerais e não só para os produtos agroprocessados, como evidenciado por VEIGA (1991). 
Observando a participação das exportações de semimanufaturados de cada mercado exportador nas exportações mundiais totais desse agregado (Tabela 7 e Figura 10), constata-se que a Europa detém uma parcela de 38,6\%, que representa basicamente as exportações da UE $(69,2 \%)$ e do EFTA (European Free Trade Arrangement) (28,4\%). O mercado norte-americano participa com $28,3 \%$ dessas exportações, que se concentram nos EUA $(52,7 \%)$ e Canadá $(46,6 \%)$. Os dois outros mercados que se destacam nas exportações de semimanufaturados são os formados pelos paises asiáticos $(15,1 \%)$ e pelos paises latino-americanos $(11,8 \%)$. Dentre esses últimos, sobressaem as exportações do MERCOSUL, sendo o Brasil e a Argentina os principais exportadores deste bloco econômico, com as respectivas participações de $54,4 \%$ e $36,6 \%$.

As taxas geométricas de crescimento calculadas para os vários periodos estudados não acrescentam novos elementos à análise, mas definem uma evolução muito semelhante entre os principais exportadores, isto é, valores relativamente altos de meados da década de 70 a início dos anos 80 , seguidos de valores negativos correspondentes à queda generalizada das exportações no início dos anos 80 , e posterior retomada do crescimento de meados de 80 até 0 final da década e início dos anos 90 . As diferenças surgem na proporção que ocorre essa retomada, que é mais acentuada nos paises asiáticos, vindo, em seguida, o mercado europeu e o norte-americano. Na América Latina, embora em proporção menor, a queda registrada no período recessivo foi também menos acentuada. O Brasil, após apresentar uma expressiva taxa de crescimento de meados de 70 a início de 80 , passou por um período de relativa estabilização. Ainda no mercado latino-americano é importante destacar as exportações argentinas de semimanufaturados, que, embora tenham uma participação proporcionalmente menor que as do Brasil, apresentaram evolução crescente em todo o periodo analisado.

\section{Manufaturados}

Os produtos classificados como manufaturados respondem por $37,2 \%$ do total mundial exportado pela agroindústria (Tabela $5 \mathrm{c}$ ). Considerando 
Tabela 7 - Exportações mundiais de produtos semimanufaturados (1000 US\$ FOB de 1992) - taxas geométricas médias anuais de crescimento entre os periodos

\begin{tabular}{|c|c|c|c|c|c|c|c|}
\hline REGIĀO/PAÍs & $1 9 7 3 \longdiv { 7 4 / 7 6 }$ & $1977 / 78 / 79$ & $1982 / 83 / 84$ & $1989 / 90 / 91$ & $\%$ & $\%$ & $\%$ \\
\hline & $\mathbf{a}$ & b & C & d & $\mathbf{b} / \mathbf{a}$ & $\mathbf{c} / \mathbf{b}$ & $d / c$ \\
\hline MUNDO & 27079677 & 40886466 & 31419999 & 46431860 & 10.86 & -6.13 & 6.74 \\
\hline EUROPA & 11690861 & 17014661 & 12421162 & 18062076 & 10.07 & -6.10 & 6.49 \\
\hline NAFTA & 10173677 & 11884912 & 9196527 & 13144664 & 3.96 & -6.00 & 6.24 \\
\hline UE & 6979693 & 10462090 & 8227.980 & 12606169 & 14.98 & -4.67 & 6.16 \\
\hline ÁsIA & 1473619 & 6372862 & 3286068 & 7010314 & 38.19 & -9.37 & 11.43 \\
\hline Estados Unidos & 6580139 & 6993662 & 6348369 & 6928170 & 6.81 & -6.22 & 3.77 \\
\hline AMÉRICA LATINA & 2259652 & 6998222 & 6473602 & 6726639 & 27.64 & -1.81 & 2.99 \\
\hline Canadá & 4668460 & 4800267 & 3768361 & 6121704 & 1.26 & -4.78 & 7.22 \\
\hline MERCOSUL & 686 & 6041658 & 4998464 & 6052473 & 27.86 & -0.17 & 2.77 \\
\hline EFTA & 123 & 473 & 2787110 & 6128146 & 2.99 & -12.96 & 9.10 \\
\hline Brasil & 886 & 927 & 717 & 3321660 & 27.69 & -1.79 & -0.76 \\
\hline Alemanha & 333 & 695 & 692 & 2714748 & 13.36 & -6.24 & 4.89 \\
\hline Argentina & 041 & 1090368 & 1368690 & 2212941 & 30.49 & 4.66 & 7.10 \\
\hline Itália & 466377 & 897 & 079 & 2192769 & 26.40 & -3.49 & 12.27 \\
\hline Suécia & 3051180 & 2619036 & 1660376 & 2162314 & -3.75 & -9.96 & 4.80 \\
\hline Holanda & 1657827 & 2466214 & 1951424 & 2101265 & 10.44 & -4.67 & 1.06 \\
\hline Finlândia & 147 & 1626122 & 210 & 1613367 & 17.33 & -7.74 & 6.80 \\
\hline França & 100 & 1693987 & 336 & 1492442 & 13.87 & -10.66 & 6.36 \\
\hline Bel-Lux & 972 & 1192761 & 663 & 1393138 & 23.48 & -3.65 & 4.99 \\
\hline "TIGRES ASIÁTICOS' & 357 & 1721647 & 836090 & 1370791 & 33.66 & -13.46 & 7.32 \\
\hline ÁFRICA & 772238 & 1143291 & 683707 & 929929. & 10.31 & -9.77 & 4.49 \\
\hline Portugal & 240262 & 239885 & 392656 & 863924 & -0.04 & 10.36 & 11.92 \\
\hline Espanha & 277888 & 667765 & 778116 & 838243 & 24.60 & 3.11 & 1.07 \\
\hline Áustria & 165600 & 466313 & 322099 & 674464 & 29.64 & -7.13 & 11.14 \\
\hline Hong Kong & 36670 & 96278 & 120958 & 637332 & 27.38 & 4.67 & 26.80 \\
\hline Reino Unido & 414100 & 669026 & 377121 & 623898 & 12.74 & -10.83 & 7.46 \\
\hline China & 24103 & 32209 & 231416 & 579290 & 7.62 & 48.35 & 14.01 \\
\hline OCEANIA & 179639 & 382927 & 506003 & 627929 & 20.83 & 6.73 & 0.61 \\
\hline Noruega & 686646 & 440620 & 302149 & 478047 & -6.91 & -7.27 & 6.77 \\
\hline Japão & 473668 & 656652 & 424965 & 320682 & 8.47 & -8.30 & -3.94 \\
\hline Coréia do Sul & 225 & 859816 & 169335 & 236180 & 686.28 & -27.74 & 4.87 \\
\hline Suica & 66193 & 197994 & 116128 & 208737 & 37.01 & -10.28 & 8.87 \\
\hline ORIENTE MÉDIO & 101469 & 66797 & 66044 & 184463 & -13.60 & -0.27 & 18.65 \\
\hline Dinamarca & 193524 & 214963 & 122432 & 184230 & 2.66 & -10.65 & 6.01 \\
\hline Cingapura & 29219 & 109902 & 120832 & 176596 & 39.26 & 1.91 & 6.67 \\
\hline Austrália & 21127 & 76377 & 65131 & 160169 & 37.44 & -2.88 & 12.68 \\
\hline Uruguai & 49608 & 73165 & 84373 & 112469 & 10.20 & 2.89 & 4.19 \\
\hline Tallândia & 17287 & 64672 & 46481 & 107317 & 39.02 & -6.36 & 12.70 \\
\hline México & 24979 & 90982 & 89798 & 94780 & 38.16 & -0.26 & 0.77 \\
\hline URSS (formal) & 638380 & 249651 & 97674 & 92863 & -20.93 & -17.11 & -0.72 \\
\hline Grécia & 34381 & 78024 & 60216 & 66544 & 22.74 & -6.05 & 1.44 \\
\hline Paraguai & 20063 & 47210 & 44675 & 61434 & 23.87 & -1.10 & 4.66 \\
\hline Irlanda & 68026 & 78796 & 27637 & 34641 & 3.74 & -18.96 & 3.33 \\
\hline
\end{tabular}

Fonte: FAO.

Obs: Os dados estão ordenados segundo a importância do mercado exportador, com base no período de 1989/90/91. 


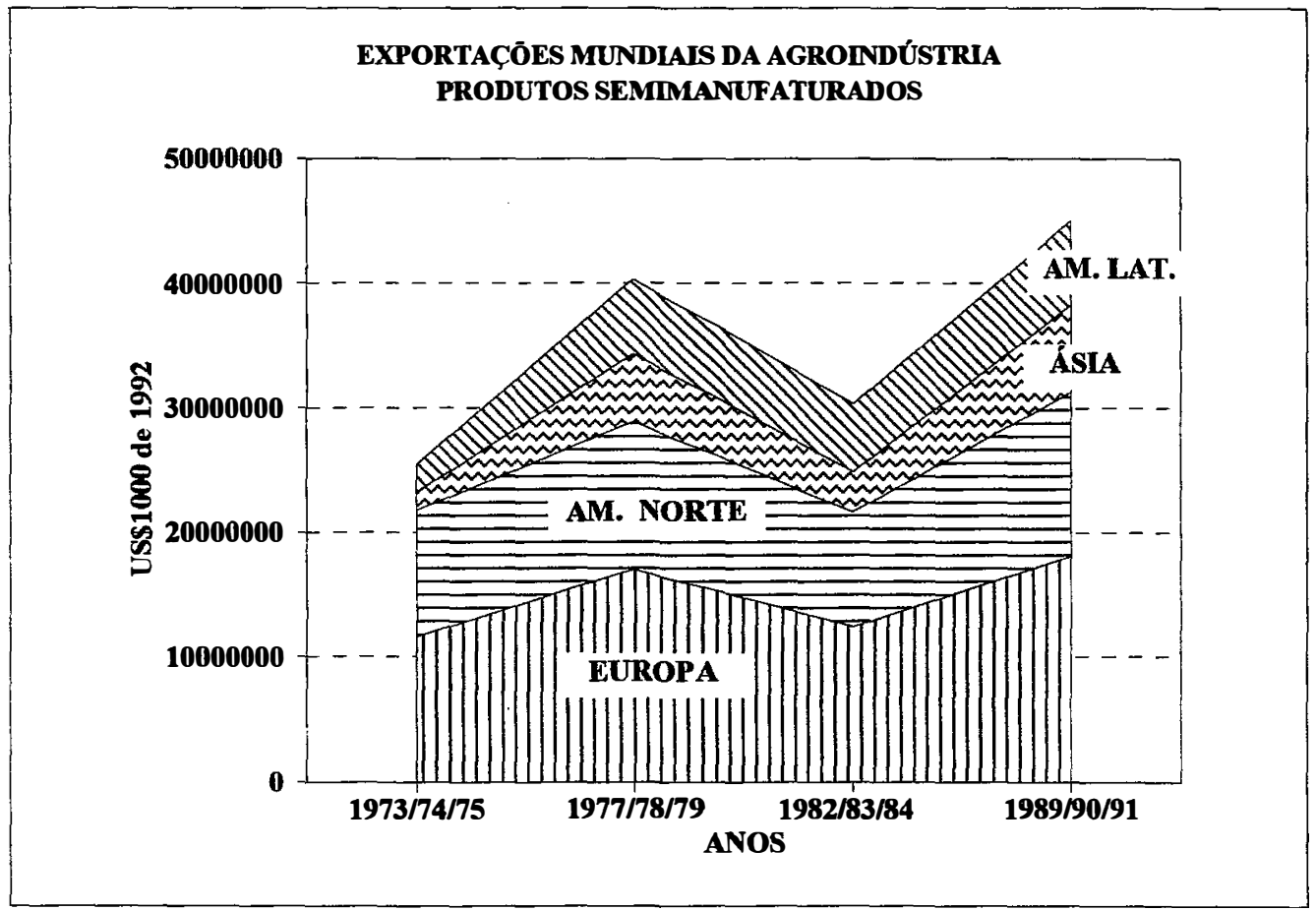

(a)

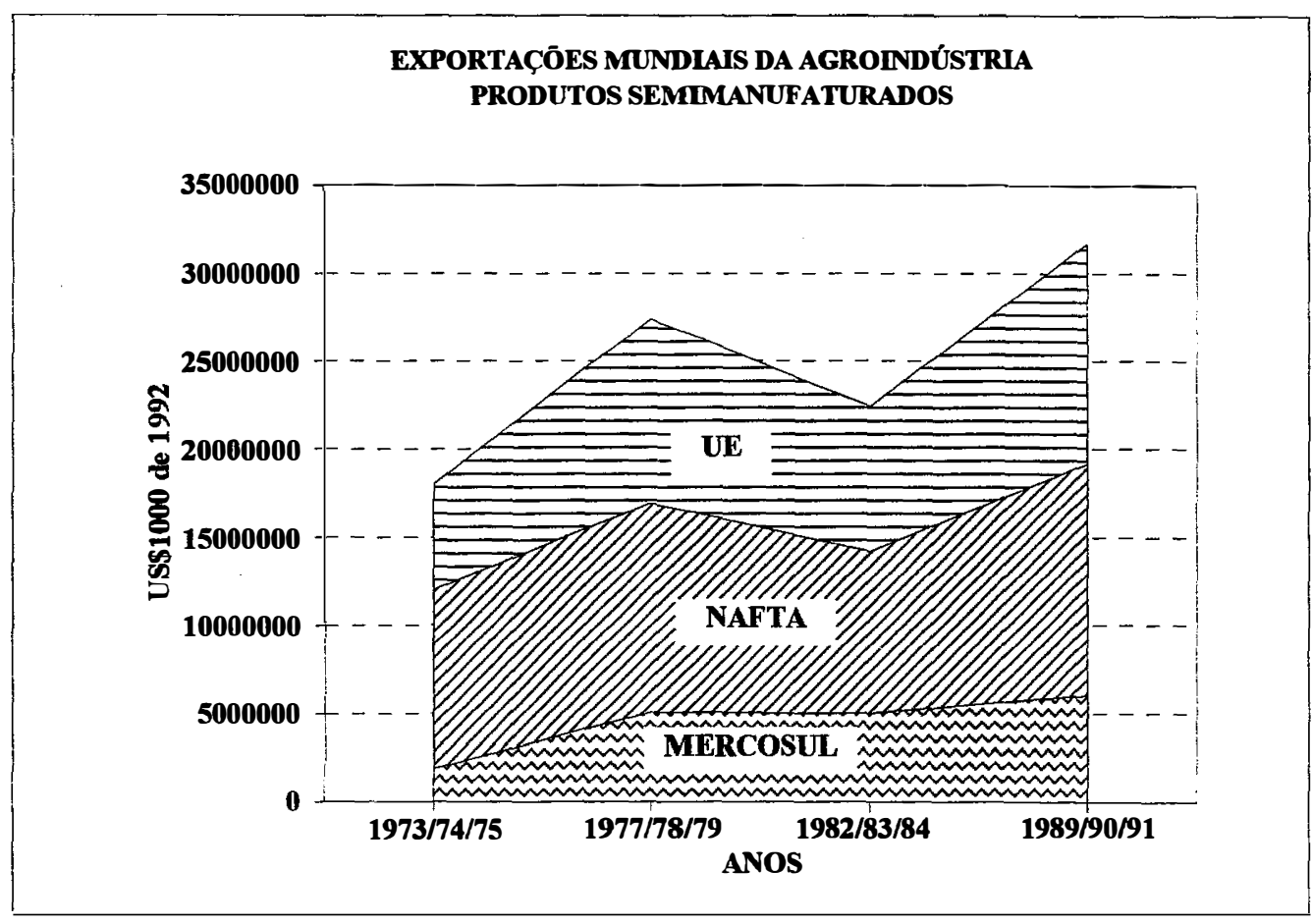

(b)

Figura 10 - Produtos semimanufaturados - evolução das exportações mundiais das principais regiōes (a) e blocos exportadores (b) 
esse total por mercado, observa-se que $51,0 \%$ das exportações agroindustriais da Europa, concentradas na UE, são de produtos manufaturados. Os paises asiáticos também mantêm uma proporção alta de manufaturados (41,5\%) na sua pauta de exportações. Nos mercados norte-americano e da América Latina, a participação de manufaturados ocorre em proporção semelhante à de semimanufaturados, ou seja, de respectivamente $23,7 \%$ e $20,5 \%$. Tratando-se de evolução, a tendência da participação de manufaturados nas exportações agroindustriais européias foi de estabilidade ao longo do período analisado. 0 mercado norte-americano apresentou também uma certa constância no nivel de participação de produtos manufaturados na pauta de exportações, embora tenha registrado acréscimo significativo de meados da década de 80 a início dos anos 90 . Esse resultado expressa a influência do crescimento das exportações de alguns produtos que compõem esse agregado, como papel e suco de laranja, e ainda a melhoria da competitividade das exportações americanas. Entre os países asiáticos observa-se uma tendência de participação crescente de manufaturados na pauta de exportações, destacando-se o incremento, nos últimos anos, das exportações de tecidos, fios de algodão e açúcar refinado.

A tendência de mudança estrutural na pauta agroexportadora para maior incremento de manufaturados começa a ser percebida também quando se analisam os dados da América Latina, do MERCOSUL e do Brasil, cujas participações vêm aumentando rapidamente desde meados da década de 70 . Como as exportações brasileiras de manufaturados representam um percentual significativo nas exportações desse agregado na América Latina $(67,6 \%)$ e no MERCOSUL (84,0\%), pode-se verificar o peso desta ocorrência específica em relação às tendências observadas no mercado latino-americano. Como o suco de laranja e o papel são os produtos agroprocessados que se destacam entre os manufaturados, a evolução crescente das exportações brasileiras destes produtos teve influência marcante no comportamento geral. Deve-se ressaltar, no entanto, que, em relação ao total específico de manufaturados exportados pela agroindústria (Tabela 8 e Figura 11), a América Latina representa apenas 6,3\% e o Brasil 4,2\%. O principal mercado exportador é o europeu, tendo os países da UE $(70,0 \%)$ e do EFTA $(28,0 \%)$ importância maior. Os mercados asiático e norteamericano têm participações semelhantes: $14,6 \%$ e $14,3 \%$, respectivamente. As taxas geométricas de crescimento confirmam situações já observadas. Ocorre um 
Tabela 8 - Exportaçōes mundiais de produtos manufaturados (1000 US\$ FOB de 1992) - taxas geométricas médias anuais de crescimento entre os períodos

\begin{tabular}{|c|c|c|c|c|c|c|c|}
\hline REGIÄO/PAÍS & $1973 / 74 / 76$ & $1977 / 78 / 79$ & $1982 / 83 / 84$ & $1989 / 90 / 91$ & $\%$ & $\%$ & $\%$ \\
\hline & a & b & c & d & $\mathbf{b} / \mathbf{a}$ & $c / b$ & $d / c$ \\
\hline & 61661367 & 76676072 & 60394367 & 97176869 & 6.61 & -4.64 & 7.03 \\
\hline A & 38607117 & 48316281 & 36374637 & 60649829 & 6.84 & -6.05 & 7.98 \\
\hline U & 25669470 & 33394003 & 24659065 & 42336166 & 6.90 & -6.96 & 8.09 \\
\hline EFTA & 10650808 & 12285683 & 9376896 & 1784087 & 3.63 & -5.26 & 8.91 \\
\hline & 668 & 8884487 & 8449668 & 14200086 & 3.05 & -1.00 & 7.70 \\
\hline NAFTA & 466 & 11386464 & 9436743 & 13878977 & 2.42 & -3.69 & 6.67 \\
\hline Alem & 695 & 989 & 6646324 & 653 & 7.22 & -4.69 & 9.06 \\
\hline "TIGRE & 602 & 6448664 & 6274193 & 8657639 & 2.41 & -0.66 & 7.16 \\
\hline Can & 726 & 347 & 801 & 6636 & 3.43 & -2.66 & 6.32 \\
\hline Fran & 240 & 073 & 034 & 3802 & 7.08 & -6.79 & 7.62 \\
\hline Finlâ & 268 & 187 & 285 & 5811 & 2.35 & -2.98 & 9.31 \\
\hline AMÉRICA L & 42 & 476 & 365 & 5230 & 17.02 & -0.61 & 2.01 \\
\hline Esta & & 366 & 400 & 836 & 1.91 & -6.23 & 6.64 \\
\hline Sué & 969 & 608 & 105 & 5121 & 3.63 & -6.06 & 9.61 \\
\hline Hole & 363 & 969 & 262 & 703 & 6.65 & -8.19 & 7.67 \\
\hline MERC & 122 & 489 & 231 & 965 & 22.97 & 2.11 & 1.61 \\
\hline Itálie & 828 & 637 & 930 & 6234 & 1.00 & -4.44 & 7.90 \\
\hline Bras & 16 & 301 & 929 & 474 & 29.03 & 4.66 & 0.88 \\
\hline Bel-Lux & 80 & 169 & 745 & 025 & 6.93 & -7.76 & 7.48 \\
\hline nido & 360 & 662 & 962 & 137 & 4.65 & -8.61 & 9.44 \\
\hline Kong & 61 & 346 & 289 & 7212 & 4.03 & 2.71 & 14.41 \\
\hline & 50 & 638 & 131 & 888 & 0.14 & -1.37 & 1.76 \\
\hline Á & 125 & 723 & 434 & 6684 & -2.37 & -4.98 & 12.05 \\
\hline Su & 24 & 126 & D 192 & 1863917 & 8.35 & -6.02 & 6.62 \\
\hline Dir & 267 & 376 & 1060 & 1842223 & 2.30 & -6.27 & 1.84 \\
\hline CoI & 124 & 608 & 231 & 1657900 & 8.49 & -1.61 & 8.10 \\
\hline JIA & 912696 & 938067 & 920962 & 1376918 & 0.69 & -0.37 & 6.90 \\
\hline $4 \boldsymbol{T}$ & 749 & 111 & 924809 & 1304695 & 8.39 & -9.14 & 6.04 \\
\hline Es & 984 & 600 & 674921 & 1222179 & 14.64 & -2.41 & 8.85 \\
\hline Norn & 876031 & 864416 & 696871 & 966239 & -0.33 & -7.14 & 7.12 \\
\hline 'E MÉDIO & 231 & 649277 & 838673 & 933422 & 7.06 & 8.83 & 1.64 \\
\hline Irla & 93 & 830023 & 640680 & 773213 & 8.26 & -8.22 & 6.25 \\
\hline Arg & 883 & 766963 & 383276 & 709769 & 8.82 & -12.96 & 9.20 \\
\hline & 60 & 861 & 426938 & 696832 & 19.00 & 14.67 & 4.91 \\
\hline & 336867 & 248688 & 192868 & 488637 & -7.25 & -4.96 & 14.20 \\
\hline & 306 & 748 & 194639 & 472605 & -9.89 & 0.61 & 13.62 \\
\hline Po & 426243 & 411486 & 318229 & 468606 & -0.82 & -6.01 & 6.68 \\
\hline & 542 & 372 & 713 & 462617 & 1.10 & 0.86 & 1.36 \\
\hline Gr & 317893 & 683413 & 448713 & 427684 & 16.39 & -6.11 & -0.69 \\
\hline $\mathrm{Ci}$ & 979 & 178176 & 116643 & 241241 & 6.11 & -8.14 & 10.96 \\
\hline URS & 120191 & 163063 & 123291 & 120363 & 6.23 & -4.23 & -0.34 \\
\hline & & & 976 & 212 & 44.05 & 16.61 & -7.4 \\
\hline
\end{tabular}

Fonte: FAO.

Obs: Os dados estão ordenados segundo a importância do mercado exportador, com base no período 1989/90/91. 


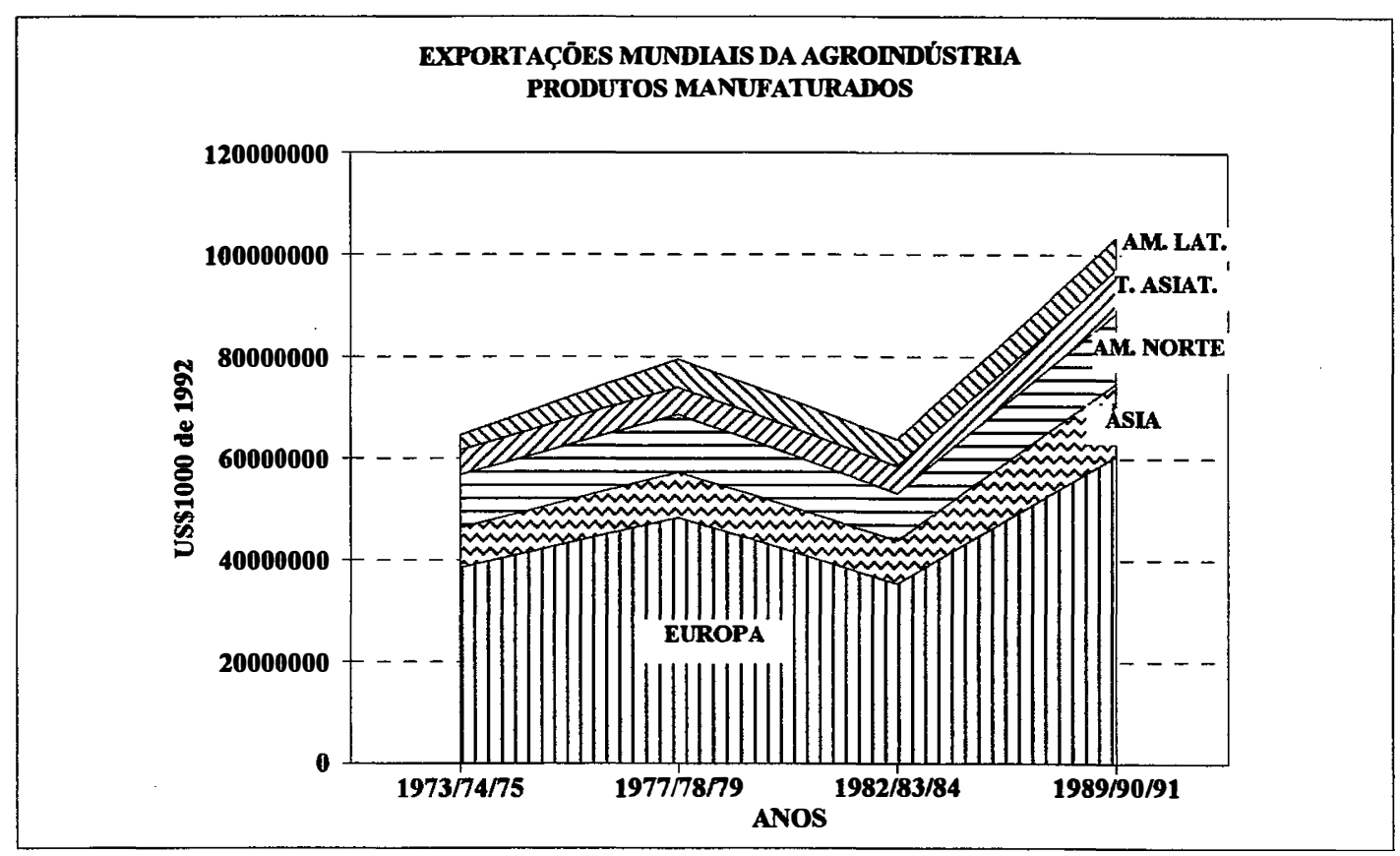

(a)

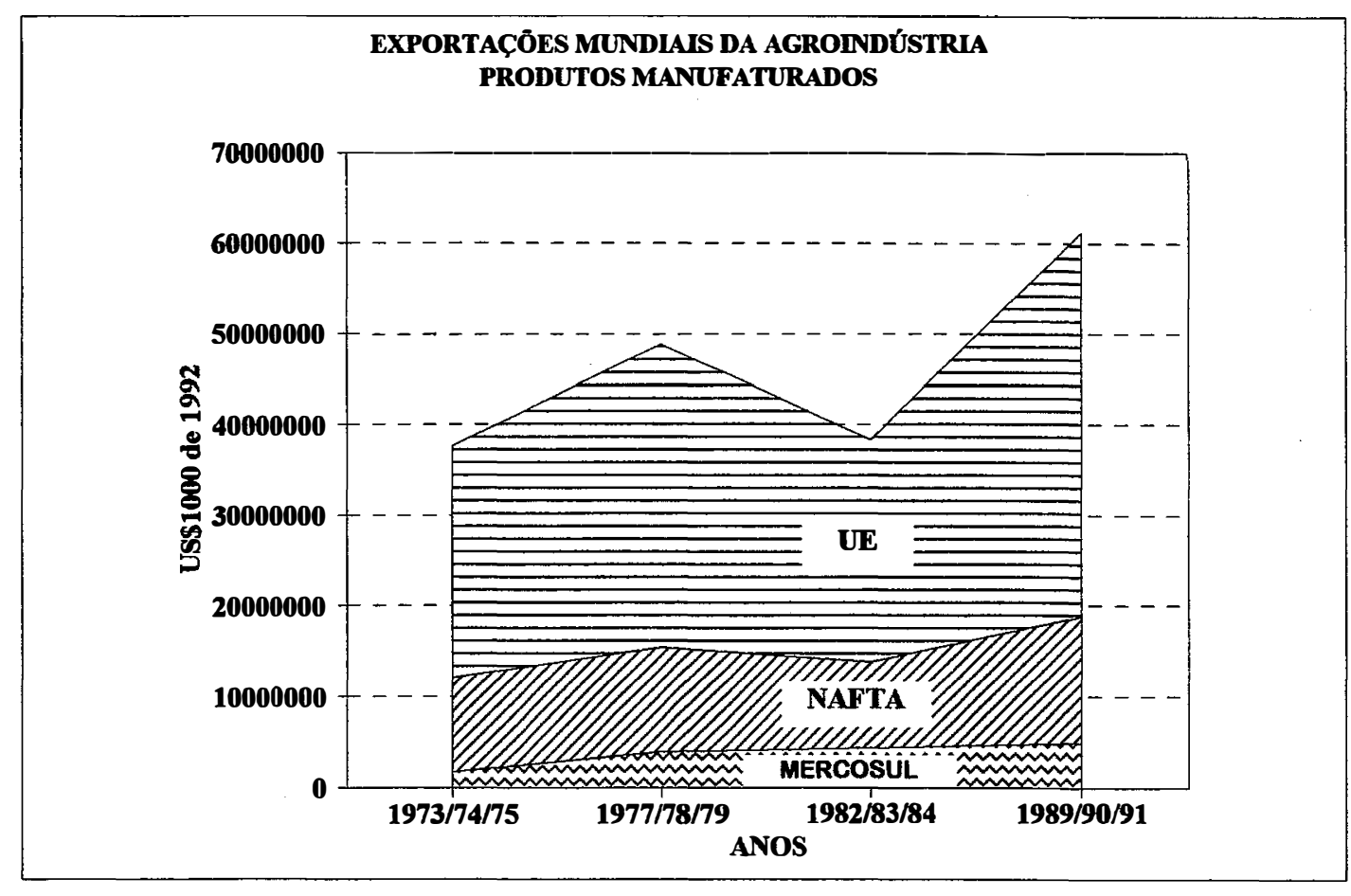

(b)

Figura 11 - Produtos manufaturados - evolução das exportações mundiais das principais regiöes (a) e blocos econômicos (b) 
comportamento evolutivo similar nas exportações de manufaturados ao longo do periodo analisado, nos principais mercados exportadores: Europa (UE e EFTA), NAFTA e Ásia, a tendência é de aumento das exportações de manufaturados, que sofrem uma queda apenas do final de 70 a início de 80 . Na América Latina, embora comportamento semelhante seja também observado, o maior impulso nas exportações de manufaturados ocorreu na década de 70 , quando a taxa de . crescimento apresentou valor significativamente alto. A partir dai observa-se uma certa estabilidade das exportações de manufaturados, que só voltaram a crescer no final de 80 e início dos anos 90 , embora em proporção menor. Ao se analisar especificamente o caso do Brasil, os dados revelam situação distinta em que as taxas geométricas de crescimento são positivas, inclusive no periodo recessivo, com valores superiores às demais, ainda que no início dos anos 90 a tendência tenha sido de maior estabilidade. Tais evidências empíricas estão a favor da hipótese do crescimento gradativo da participação de produtos agroindustriais manufaturados na pauta de exportações brasileiras, nas últimas décadas, em detrimento dos mercados de produtos básicos tradicionais.

\subsection{TENDÊNCIAS DAS EXPORTAÇÕES POR AGRUPAMENTO DE PRODUTOS}

\section{Cereais}

Este grupo representa a soma dos valores exportados de trigo, milho, arroz, cevada, aveia e centeio. Das exportações totais de cereais em nivel mundial, trigo, milho e arroz são os produtos mais importantes com participações respectivas de $45,0 \%, 28,0 \%$ e $13,0 \%$. A cevada também detém uma parcela relativamente significativa do mercado exportador $(9,0 \%)$ e os demais, centeio e aveia não chegam a ter $1,0 \%$ de participação.

Quanto aos mercados continentais, o principal exportador de cereais é o mercado norte-americano ( $45,5 \%$ do total), basicamente concentrado nos EUA, que representa $78,2 \%$ das exportações (Tabela 9 e Figura 12). Apesar dessa liderança, as taxas geométricas de crescimento têm registrado decréscimos 
Tabela 9 - Exportações mundiais de cereais (trigo, milho, arroz, cevada, aveia e centeio), (1000 US\$ FOB de 1992) e taxas geométricas médias anuais de crescimento entre os periodos

\begin{tabular}{|c|c|c|c|c|c|c|c|}
\hline REGIÁO/PAIS & $1973 / 74 / 75$ & 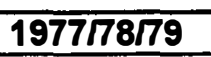 & $1982 / 83 / 84$ & $1989 / 90 / 91$ & $\%$ & $\%$ & $\%$ \\
\hline $\begin{array}{l}\text { MUNDO } \\
\text { NAFTA }\end{array}$ & $\begin{array}{c}a \\
48143818 \\
26988772\end{array}$ & $\begin{array}{c}\frac{b}{47195188} \\
25321754\end{array}$ & $\begin{array}{c}c \\
40758229 \\
22299849\end{array}$ & $\begin{array}{c}d \\
33954903 \\
16466158\end{array}$ & $\begin{array}{r}b / a \\
-0.50 \\
-1.58\end{array}$ & $\begin{array}{l}c / b \\
-3.60 \\
-2.51\end{array}$ & $\begin{array}{l}d / c \\
-4.46 \\
-5.09\end{array}$ \\
\hline Estados Unidos & 22122188 & 21129285 & 17158460 & 12101926 & -1.14 & -4.08 & -4.87 \\
\hline EUROPA & 8938604 & 9985046 & 8493917 & 10696087 & 2.81 & -3.18 & 3.35 \\
\hline UE & 7392767 & 8537838 & 7241621 & 9767604 & 3.67 & -3.24 & $\begin{array}{l}4.37 \\
30 ?\end{array}$ \\
\hline $\begin{array}{l}\text { França } \\
\text { ÁsIA }\end{array}$ & $\begin{array}{l}4392062 \\
4137290\end{array}$ & $\begin{array}{l}4747860 \\
4395789\end{array}$ & $\begin{array}{l}4085448 \\
3569630\end{array}$ & $\begin{array}{l}5345609 \\
3673287\end{array}$ & $\begin{array}{l}1.97 \\
1.53\end{array}$ & $\begin{array}{l}-2.96 \\
-4.08\end{array}$ & $\begin{array}{l}3.92 \\
0.41\end{array}$ \\
\hline Canadá & 4849977 & 4169944 & 5139416 & 3352540 & -3.71 & 4.27 & -5.92 \\
\hline OCEANIA & 2527566 & 2618155 & 2531386 & 2069020 & 0.88 & -0.67 & -2.84 \\
\hline Austrália & 2523314 & 2597300 & 2515204 & 2061611 & 0.73 & -0.64 & -2.80 \\
\hline Tailândia & 1282533 & 1662207 & 1632805 & 1496148 & 6.70 & -0.36 & -1.24 \\
\hline AMÉRICA LATINA & 2972037 & 3216944 & 2985456 & 1447381 & 2.00 & -1.48 & -9.83 \\
\hline MERCOSUL & 2779413 & 3010064 & 2880041 & 1326705 & 2.01 & -0.88 & -10.48 \\
\hline Argentina & 2452089 & 2736305 & 2687796 & 1157482 & 2.78 & -0.36 & -11.34 \\
\hline Reino Unido & 202011 & 487125 & 989941 & 1042757 & 24.61 & 15.24 & 0.75 \\
\hline China & 1601187 & 784968 & 378997 & 777040 & -16.32 & -13.55 & 10.80 \\
\hline Grécia & 242857 & 271902 & 252018 & 568943 & 2.86 & -1.51 & 12.34 \\
\hline Alemanha & 360347 & 422943 & 261283 & 553602 & 4.09 & -9.18 & 11.32 \\
\hline ÁFRICA & 1177427 & 854161 & 460136 & 448509 & -7.71 & -11.64 & -0.36 \\
\hline Dinamarca & 228062 & 314614 & 199677 & 448278 & 8.38 & -8.69 & 12.25 \\
\hline Itália & 309149 & 398595 & 353421 & 446305 & 6.56 & -2.38 & 3.39 \\
\hline Espanha & 67478 & 47436 & 46095 & 439876 & -8.43 & -0.57 & 38.02 \\
\hline ORIENTE MÉDIO & 87470 & 367099 & 239756 & 438951 & 43.13 & -8.17 & 9.02 \\
\hline Holanda & 1137482 & 925127 & 214815 & 424281 & -5.03 & -25.33 & 10.21 \\
\hline Bel-Lux & 434772 & 848702 & 801893 & 399083 & 18.20 & -1.13 & -9.49 \\
\hline EFTA & 323812 & 313470 & 318648 & 284237 & -0.81 & 0.33 & -1.62 \\
\hline URSS (formal) & 1418730 & 825864 & 419829 & 166154 & -12.65 & -12.66 & -12.40 \\
\hline Uruguai & 69604 & 96548 & 121773 & 132571 & 8.52 & 4.75 & 1.22 \\
\hline Áustria & 2174 & 48213 & 119780 & 117441 & 117.01 & 19.96 & -0.28 \\
\hline Suécia & 291190 & 202905 & 152441 & 107673 & -8.64 & -5.56 & -4.85 \\
\hline Irlanda & 16688 & 73471 & 36480 & 84774 & 44.85 & -13.07 & 12.80 \\
\hline Finlândia & 21933 & 55907 & 45162 & 58404 & 26.36 & -4.18 & 3.74 \\
\hline "TIGRES ASIÁTICOS" & 224858 & 214748 & 345211 & 40816 & -1.14 & 9.96 & -26.29 \\
\hline Paraguai & 1410 & 202 & 1507 & 34465 & -38.48 & 49.47 & 56.38 \\
\hline Cingapura & 69993 & 72062 & 226167 & 22934 & 0.73 & 25.70 & -27.89 \\
\hline Hong Kong & 23474 & 2802 & 5212 & 16385 & -41.22 & 13.22 & 17.78 \\
\hline Portugal & 1858 & & 549 & 14096 & -56.96 & 53.83 & 58.98 \\
\hline México & 16607 & 22524 & 1973 & 11692 & 7.92 & -38.55 & 28.94 \\
\hline Brasil & 256310 & 177009 & 68965 & 2187 & -8.84 & -17.18 & -38.92 \\
\hline Coreia do Sul & 7309 & 20122 & 13200 & 1363 & 28.81 & -8.09 & -27.70 \\
\hline Suíca & 737 & 774 & 382 & 539 & 1.24 & -13.17 & 5.04 \\
\hline $\begin{array}{l}\text { Noruega } \\
\text { Japão }\end{array}$ & $\begin{array}{r}7779 \\
124081\end{array}$ & $\begin{array}{r}5670 \\
119762\end{array}$ & $\begin{array}{r}882 \\
100633\end{array}$ & $\begin{array}{l}180 \\
134\end{array}$ & $\begin{array}{l}-7.60 \\
-0.88\end{array}$ & -31.07 & -20.31 \\
\hline Jap & 124081 & 119762 & 100633 & 134 & -0.88 & -3.42 & -61.15 \\
\hline
\end{tabular}

Fonte: FAO.

Obs: Os dados estão ordenados segundo a importância do mercado exportador, com base no período de 1989/90/91. 


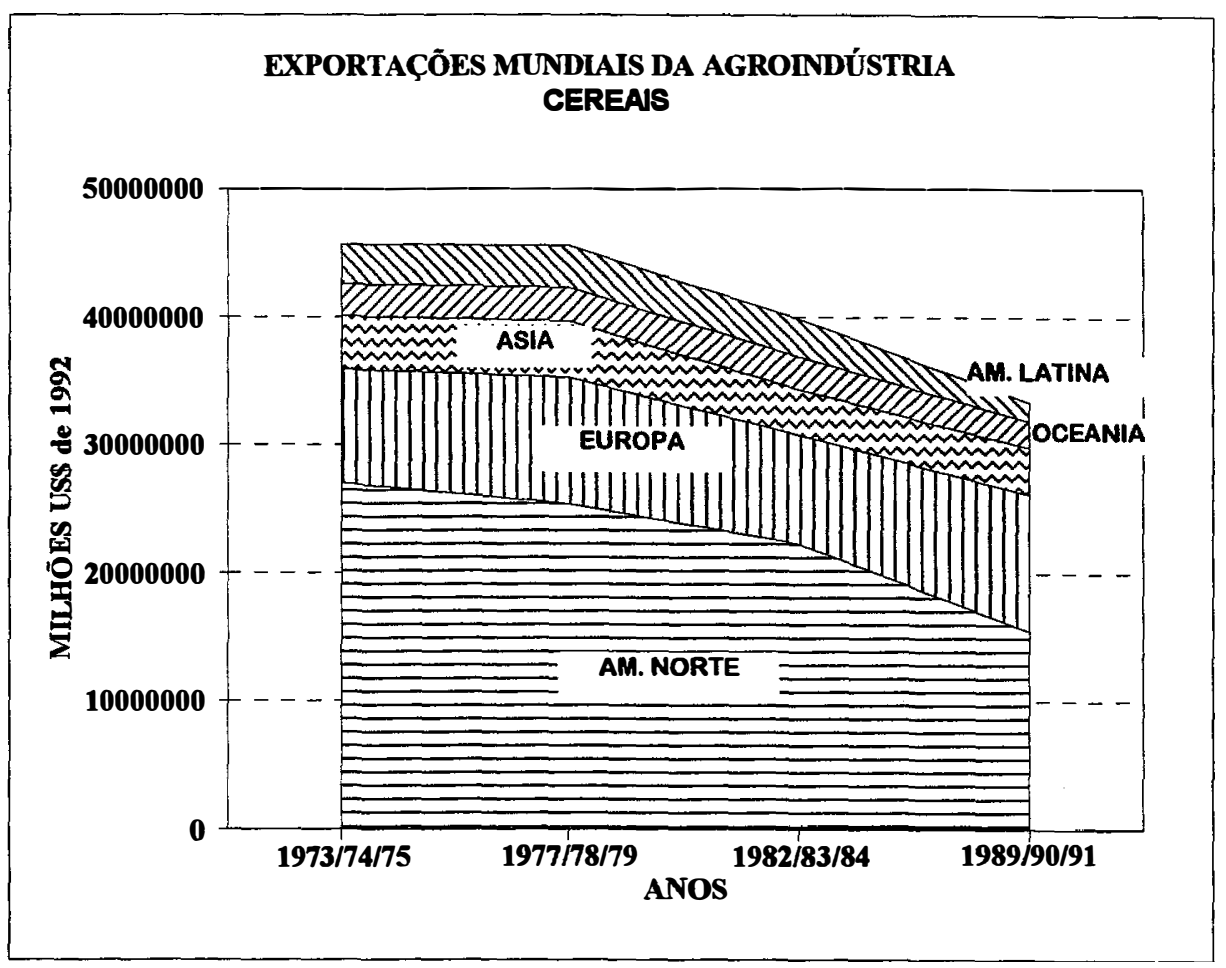

(a)

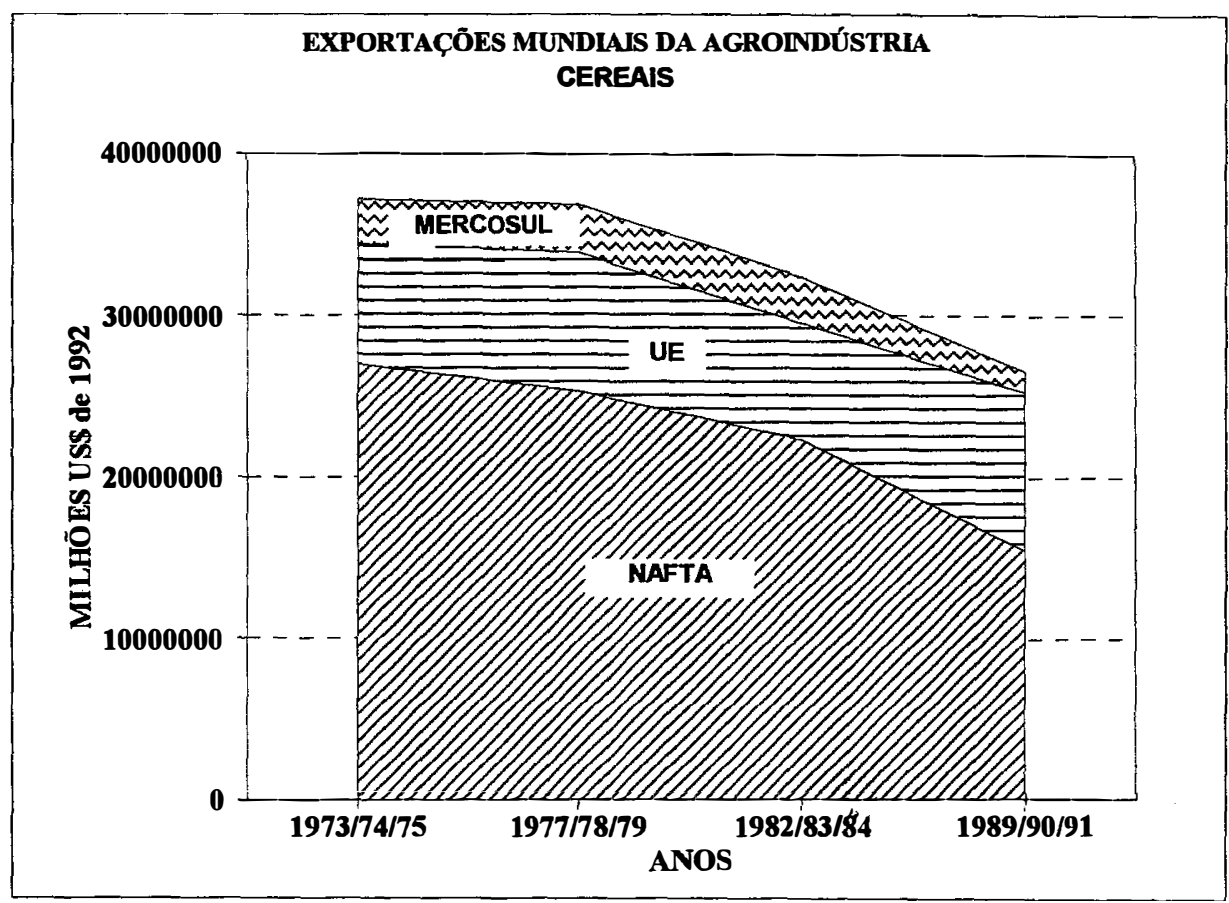

(b) 
no valor exportado, nos periodos analisados, embora em proporções mais acentuadas nos últimos periodos, o que estaria refletindo a queda de preços reais dos cereais em função do desequilibrio entre oferta e demanda, causado em parte pela apreciação do dólar frente às moedas européias, durante a primeira metade da década de 80 , tomando as exportações menos competitivas. A Europa posiciona-se como o segundo maior exportador de cereais do mundo (31,5\%), classificação que, na verdade é devido às exportações da UE, bloco econômico que concentra $91,3 \%$ do total. Mesmo com preços internacionais abaixo das médias já alcançadas em periodos anteriores, a UE manteve em alta suas exportações de cereais, como refletem as taxas de crescimento positivas, exceto as do final da década de 70 para o início dos anos 80 , periodo em que a recessão mundial foi intensa e a queda do valor exportado, uma ocorrência generalizada. As politicas agricolas adotadas pelos paises desenvolvidos (particularmente da UE e EUA) foram, como já mencionado, fundamentais para a formação e colocação dos excedentes exportáveis no mercado externo.

A perda da dinâmica das exportações de cereais da América Latina do final da década de 70 até o início dos anos 90 refletiu-se nas taxas geométricas de crescimento, que passam a valores negativos nos últimos periodos analisados (-1,5\% e -9,8\%). Em relação ao comércio mundial, essa região passou de uma participação de $6,2 \%$ em 1973/74/75 para a de 4,3\% em 1989/90/91.

A Argentina situa-se como o principal pais exportador de cereais da América Latina com uma participação de $80,0 \%$. Referindo-se à perda de volume exportado, a Argentina seguiu a mesma tendência do mercado latino- americano, apresentando taxas geométricas de crescimento negativas de $-0,4 \%$ e $-11,3 \%$ nos últimos periodos analisados.

O Brasil é um país inexpressivo no comércio mundial de cereais, tendo se caracterizado desde a década de 70 como um importador líquido. As taxas de crescimento de suas exportações de cereais, $-8,8 \%,-17,2 \%$ e $38,9 \%$, nos quatros periodos analisados, revelam a brutal perda de espaço e a reversão da situação de décadas passadas. Esses resultados confirmam a crescente participação do Brasil não só nas importações mundiais de produtos tradicionalmente importados, como trigo e cevada mas também de arroz e milho, especialmente nos momentos de crise de oferta e, ou, demanda, como observado 
em recente análise feita por JANK (1994). Em sintese, o que os dados analisados confirmam é a manutenção da liderança dos EUA e da UE no comércio mundial de cereais desde meados de 70 , mesmo com os decréscimos observados no final desta década e no início dos anos 80 que na verdade, significam uma desaceleração de exportações, dada a queda da demanda mundial e não perda da hegemonia do comércio.

A análise desagregada revela que o mercado norte-americano tem maior importância nas exportações de milho $(62,7 \%)$, trigo $(46,0 \%)$ e outros cereais $(71,1 \%)$. Analisando os dados por pais, os EUA dominam esse mercado exportador com participações respectivas de 99,3\% , 61,0\% e 96,0\%. O mercado europeu (basicamente a UE) tem participação menos expressiva nas exportações desses produtos, com $21,8 \%$ (milho), 35,2\% (trigo) e 6,7\% (outros cereais). Para os três outros produtos considerados, centeio, cevada e aveia, a situação se inverte, já que o mercado europeu domina as exportações com participações de, respectivamente, $68,0 \%, 68,5 \%$ e $54,0 \%$, sendo a UE o principal exportador. As exportações norte-americanas são menos expressivas, representando uma parcela de $30,0 \%$ (centeio), $20,5 \%$ (cevada) e $30,0 \%$ (aveia), sendo o Canadá o principal pais exportador.

Finalmente, quanto ás exportações de arroz, são basicamente originadas da Ásia (54,7\% das exportações mundiais), com 55,2\% provenientes só da Tailândia. Os EUA e a UE representam, respectivamente, $19,0 \%$ e 18,0\% do comércio mundial exportador deste produto.

\section{Grãos Oleaginosos}

Dos grãos que compõem este grupo (soja, algodão, girassol e colza), permanece como líder no comércio mundial o grão de soja, cujas exportações chegaram a representar $87,0 \%$ do total em meados da década de 70 . Este percentual, no inicio dos anos 90 , caiu para $70,0 \%$. A comercialização mundial de semente de colza seguiu trajetória inversa, evoluindo de uma participação de $9,0 \%$ do valor das exportações mundiais de grãos oleaginosos para $18,3 \%$ no mesmo período. As exportações de semente de girassol representaram uma parcela menor do mercado (11,3\%), mas vêm mantendo taxas 
de crescimento positivas nos periodos analisados. As exportações de algodão em semente são inexpressivas $(0,7 \%$ do total exportado).

A Tabela 10 e Figura 13 mostram que, em termos totais, também o mercado norte-americano domina o comércio mundial de grãos oleaginosos, com uma participação de $52,3 \%$, tendo os EUA como principal exportador responsável por $87,0 \%$ do total exportado. O mercado europeu fica em segundo lugar $(22,2 \%)$, com as exportações da UE detendo $88,0 \%$ do total.

Com relação à evolução das exportações no periodo analisado, ocorre no caso dos grãos oleaginosos fenômeno semelhante ao observado com o grupo dos cereais. Apesar da posição de liderança ocupada pelos EUA, as taxas geométricas de crescimento foram negativas no periodo de $1977 / 78 / 79$ para $1982 / 83 / 84(-6,7 \%)$, e deste periodo para 1989/90/91 (-7,60\%), enquanto as exportações originadas da UE, embora em menor proporção, mantiveram taxas de crescimento positivas e relativamente altas em todos os periodos $(4,6 \% ; 17,8 \%$ e $11,3 \%$, respectivamente).

A soja destaca-se como principal grão oleaginoso exportado pelos EUA, com uma participação de $63,7 \%$ das exportações desse grupo, mas vem apresentando taxas de crescimento negativas nos periodos mais recentes. A América Latina é o segundo mercado exportador de soja em grão, participando com $28,0 \%$ do total de grãos comercializados. Embora tenha ocorrido decréscimo em suas exportações do final de 70 para inicio dos anos 80 , estas voltaram a crescer e recuperaram os niveis atingidos na década de 70.

Em relação a bloco econômico, o MERCOSUL é um exportador importante (27,5\% do total mundial), liderado pelas exportações do Brasil e Argentina, que representam, respectivamente, $50,3 \%$ e $33,3 \%$ do total exportado de grãos oleaginosos.

As exportações de colza em grão tem como mercado mais importante a Europa (65,0\% do total mundial), principalmente em razão das exportações da UE, que representam 83,2\%, sendo a França o principal exportador $(52,0 \%)$. A julgar pelas altas taxas geométricas de crescimento, mantidas desde o final da década de 70 , é um mercado em expansão e de grande concorrência com a soja, principalmente para produção de óleo comestivel. $\mathrm{O}$ 
Tabela 10 - Exportaçoes mundiais de graos oleaginosos (soja, colza, girassol e algodao), (1000 US\$ FO de 1992) e taxas geométricas médias anuais de crescimento entre os períodos

\begin{tabular}{|c|c|c|c|c|c|c|c|}
\hline REGIAO/PAIS & $1973 / 7476$ & $1 9 7 7 \longdiv { 7 8 / 7 9 }$ & $1982 / 83 / 84$ & $1989 / 90 / 91$ & $\%$ & $\%$ & $\%$ \\
\hline & $a$ & $\mathbf{b}$ & C & d & b/a & $\mathrm{c} / \mathbf{b}$ & $\mathrm{d} / \mathrm{c}$ \\
\hline MUNDO & 9712865 & 13434611 & 9986814 & 8569833 & 8.46 & -6.76 & -2.18 \\
\hline NAFTA & 7671173 & 11066900 & 7790074 & 4478430 & 9.93 & -6.76 & -7.60 \\
\hline Estados Unidos & 7014966 & 10232646 & 7251294 & 3886440 & 9.90 & -6.66 & -8.63 \\
\hline EUROPA & 463208 & 607772 & 891647 & 1900746 & 2.88 & 11.92 & 11.42 \\
\hline AMÉRICA LATINA & 1365671 & 1666401 & 1092808 & 1728081 & 6.09 & -8.08 & 6.77 \\
\hline MERCOSUL & 1366024 & 1657435 & 1092116 & 1706640 & 6.16 & -8.00 & 6.69 \\
\hline UE & 292239 & 349711 & 793086 & 1676061 & 4.69 & 17.79 & 11.28 \\
\hline França & 121077 & 78460 & 498489 & 1126236 & -10.28 & 44.76 & 12.36 \\
\hline Brasil & 1323710 & 668378 & 343180 & 827376 & -16.70 & -12.48 & 13.40 \\
\hline Argentina & 206 & 876835 & 639871 & 609097 & 707.29 & -6.09 & -0.70 \\
\hline Canadá & 666093 & 824191 & 638721 & 692903 & 10.34 & -8.16 & 1.38 \\
\hline ASIA & 206968 & 136461 & 194326 & 360542 & -9.96 & 7.49 & 9.23 \\
\hline China & 183306 & 968 & 168346 & 317790 & -11.79 & 8.69 & 9.60 \\
\hline Paraguai & 32108 & 110685 & 105640 & 264772 & 36.26 & -0.93 & 14.03 \\
\hline Alemanha & 48242 & 61641 & 49765 & 174488 & 1.67 & -0.70 & 19.63 \\
\hline Dinamarca & 67316 & 78773 & 129666 & 146910 & 4.01 & 10.48 & 1.70 \\
\hline Holanc & 40612 & 127784 & 62734 & 86216 & 33.19 & -16.22 & 7.28 \\
\hline Reino Unido & 2970 & 3961 & 48636 & 74177 & 7.47 & 65.13 & 6.22 \\
\hline OCEANIA & 12646 & 8926 & 4963 & 33238 & -8.16 & -11.07 & 31,22 \\
\hline Austrália & 12546 & 8873 & 4727 & 32036 & -8.29 & -11.83 & 31.44 \\
\hline Espanha & 414 & 2216 & 693 & 30692 & 62.11 & -20.74 & 71.86 \\
\hline EFTA & 80273 & 40476 & 31904 & 26516 & -16.73 & -4.65 & -2.61 \\
\hline AFRICA & 66978 & 43422 & 13051 & 22266 & -6.57 & -21.37 & 7.93 \\
\hline Austria & 2866 & 3432 & 2714 & 16604 & 4.71 & -4.59 & 28.39 \\
\hline Bel-Lux & 3236 & 6625 & 6631 & 12986 & 14.31 & 3.72 & 10.08 \\
\hline Itália & 423 & 906 & 368 & 12169 & 20.99 & -16.48 & 64.82 \\
\hline "TIGRES ASIATICOS" & 3962 & 13019 & 11653 & 11983 & 34.64 & -2.36 & 0.62 \\
\hline Suécia & 77321 & 36867 & 28879 & 10429 & -16.91 & -4.76 & -13.64 \\
\hline Irlanda & 61 & 74 & 2293 & 6665 & 6.23 & 98.47 & 16.46 \\
\hline Cingapura & 2834 & 9773 & 8032 & 6609 & 36.27 & -3.85 & -2.76 \\
\hline Hong Kong & 1083 & 3054 & 3386 & 5163 & 29.69 & 2.09 & 6.18 \\
\hline Grécia & 63 & 101 & 20 & 4482 & 17.36 & -27.88 & 117.12 \\
\hline ORIENTE MÉDIO & 2894 & 698 & 229 & 1112 & -29.92 & -20.00 & 26.34 \\
\hline Tailândia & 11720 & 9909 & 4707 & 701 & -4.11 & -13.83 & -23.82 \\
\hline
\end{tabular}

Fonte: FAO.

Obs: Os dados estao ordenados segundo a importância do mercado exportador, com base no período de 1989/90/91. 


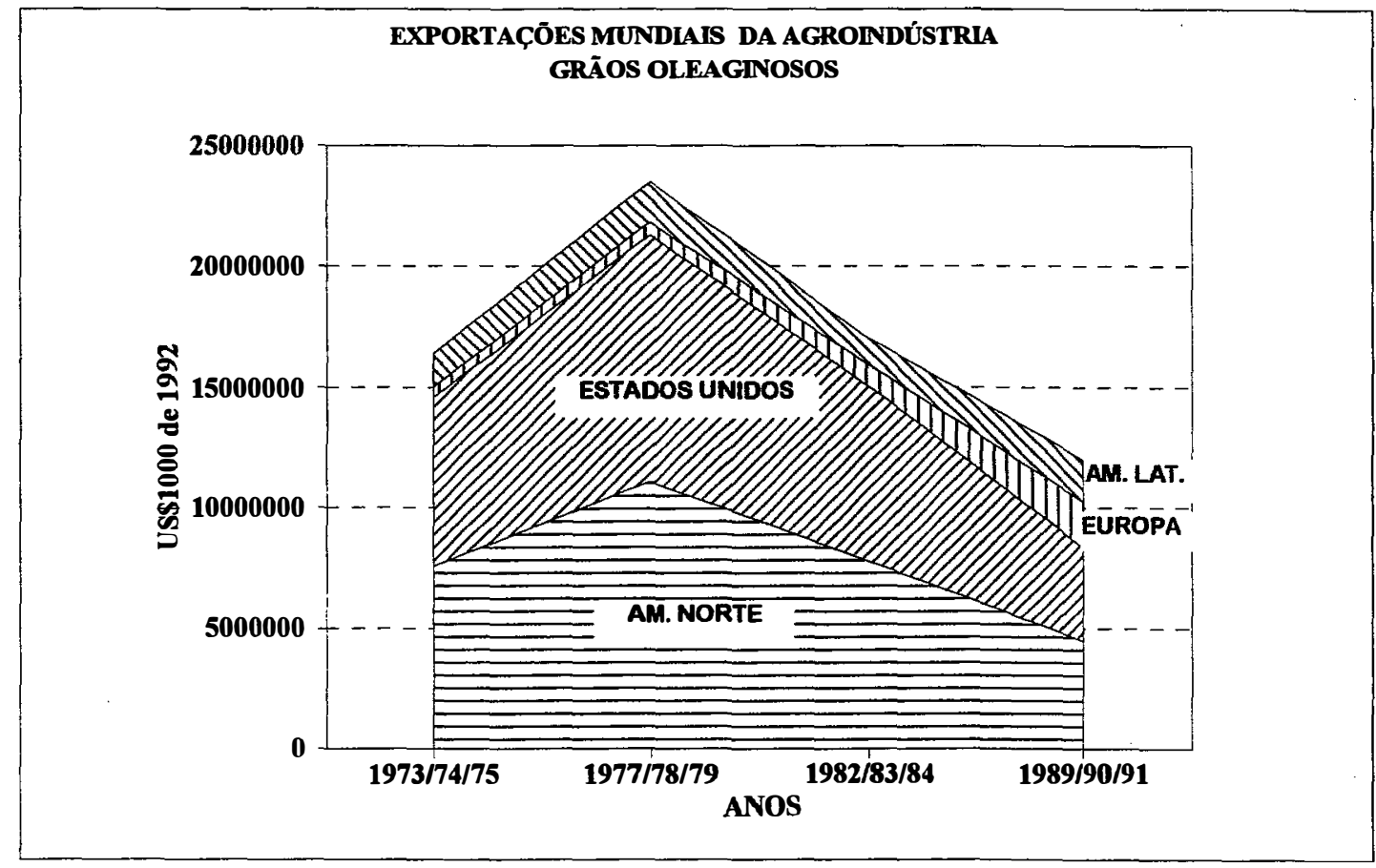

(a)

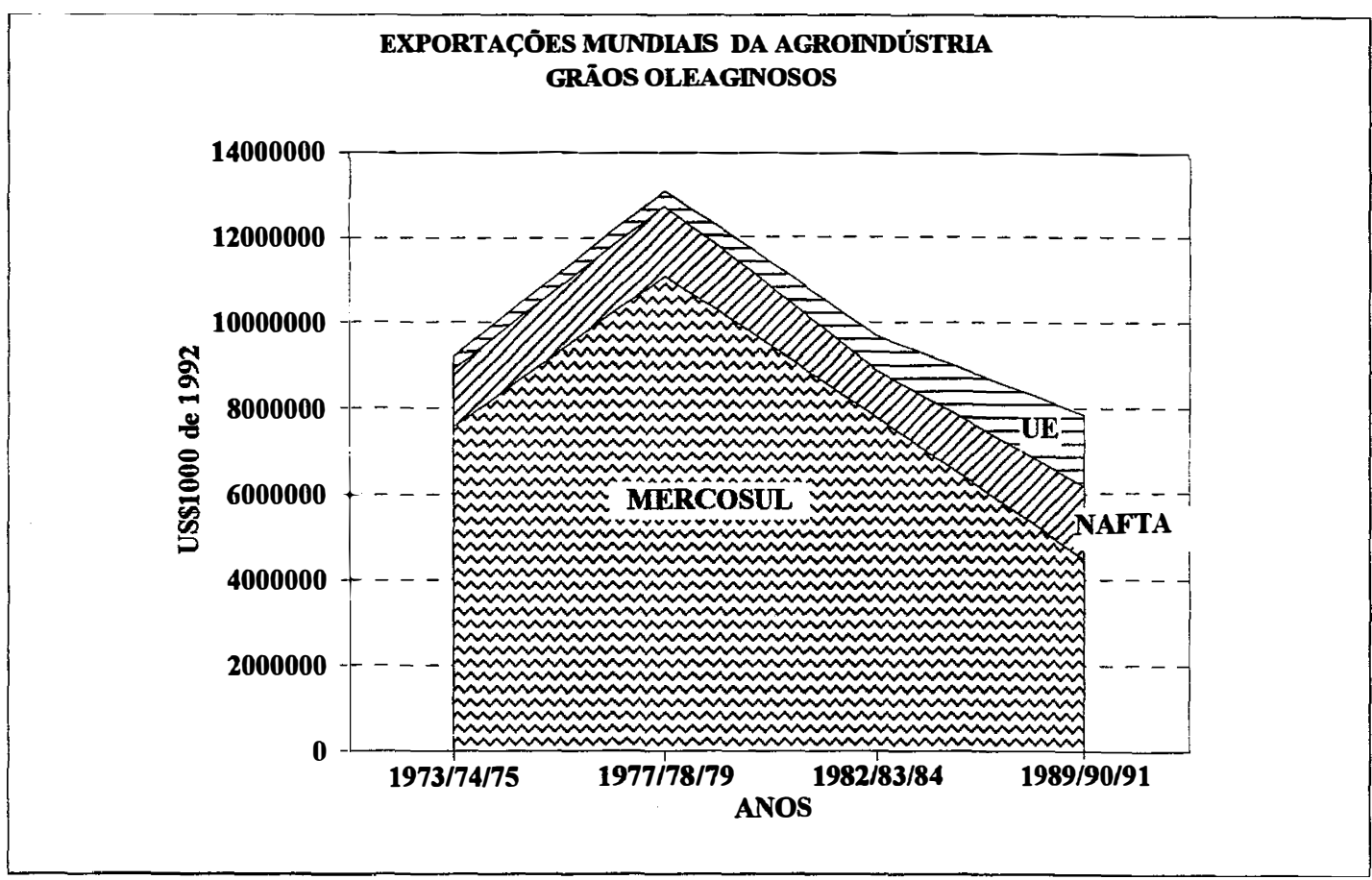

(b)

Figura 13 - Graos oleaginosos - evoluçao das exportaçoes mundiais das principais regioes (a) e blocos económicos (b) 
mercado norte-americano tem também posição de destaque nas exportações de colza em grão ( $34,0 \%$ do total mundial), com $99,0 \%$ provenientes do Canadá.

Do total exportado de grãos oleaginosos, o girassol representa $11,3 \%$ e tem $75,0 \%$ de suas exportações concentradas na UE, sendo a França o principal pais exportador $(93,0 \%)$. Apesar de ser um produto de menor importância relativa, o girassol vem apresentando, no mercado europeu, taxas de crescimento significativamente altas, desde o inicio do periodo analisado, revelando assim um dinamismo exportador que merece atenção. Os EUA participam de uma parcela pequena deste mercado $(6,7 \%)$ e apresentam perda de dinamismo desde o inicio dos anos 80, mais acentuada nos anos recentes, expressa pelas taxas de crescimento negativas de suas exportações. A América Latina detém um percentual semelhante ao dos EUA (6,5\%), basicamente pelas exportações da Argentina $(98,4 \%)$, cuja taxa de crescimento apresentou valor alto e positivo no último periodo analisado $(6,8 \%)$.

É praticamente desprezivel, em termos relativos, o valor total exportado de algodão em semente $(0,7 \%$ do total mundial), proveniente da Austrália $(32,0 \%)$, da África $(28,4 \%)$ e dos EUA $(22,5 \%)$.

\section{Óleos Vegetais}

Neste grupo incluem-se os óleos de soja, algodão, colza, girassol e milho. É um mercado exportador de grande concorrência, mais forte entre os óleos de soja, colza e girassol. Atualmente, a Europa é o maior exportador mundial de óleos, participando com $44,8 \%$ do total exportado, e $90,4 \%$ deste total é proveniente da UE. O mercado norte-americano representa uma parcela bem inferior $(16,0 \%)$, basicamente originada dos EUA $(84,0 \%)$. Observa-se, pela análise das taxas geométricas de crescimento, que as exportações de óleo nestes mercados vêm sofrendo pequenos decréscimos desde o final da década de 70 , um pouco mais acentuados no mercado norte-americano (Tabela 11 e Figura 14).

A América Latina é um importante mercado exportador de óleos, ocupando o segundo lugar, com uma participação de $30,0 \%$ em relação ao total 
Tabela 11 - Exportações mundiais de óleos vegetais (soja, girassol, colza, algodão e milho), (1000 US\$ FOB de 1992) e taxas geométricas médias anuais de crescimento entre os períodos

\begin{tabular}{|c|c|c|c|c|c|c|c|}
\hline REGIAOO & $1973 / 74 / 76$ & $977 / 78 / 79$ & $982 / 83 / 84$ & 1989/90/91 & $\%$ & $\%$ & $\%$ \\
\hline & $\overline{\mathbf{a}}$ & $\mathbf{b}$ & $\bar{c}$ & d & b/a & $a / b$ & d/c \\
\hline MU & 3903366 & 6532850 & 668058 & 4430078 & 9.11 & -3.34 & -0.74 \\
\hline & 363765 & 38480 & 2064781 & 1982 & 8.18 & -4.05 & -0.68 \\
\hline $\mathbf{U}$ & 7185 & 2067656 & 1762904 & 2680 & 9.39 & -3.16 & 0.32 \\
\hline AME & 228066 & 669 & 1206932 & 1331160 & 41.98 & 6.43 & 1.41 \\
\hline MERC & 208173 & 362 & 1206021 & 808 & 44.73 & 6.70 & 1.21 \\
\hline Arge & 69643 & 301794 & 657865 & 606 & 0.04 & 13.07 & 7.89 \\
\hline NAFTA & 1136792 & 1706778 & 1125642 & 701488 & 10.72 & -7.99 & -6.63 \\
\hline Estado & 285 & 1686572 & 101 & 776 & 9.61 & -8.60 & -7.60 \\
\hline & 682 & 946 & & 01 & 6.60 & -7.39 & 0.69 \\
\hline $\mathrm{He}$ & 36 & 383 & 178 & 206 & 7.14 & -0.93 & 0.29 \\
\hline $\mathbf{B}$ & 290 & 606784 & 64 & 369 & 42.71 & 1.12 & -8.49 \\
\hline ÁSIA & 54473 & 77819 & 083 & 923 & 9.33 & 17.87 & 9.44 \\
\hline -Lux & 305 & 832 & 04 & 168 & 6.07 & 2.27 & 4.93 \\
\hline $\mathbf{F}$ & 60 & 906 & 222 & 512 & 6.88 & -8.46 & 1.38 \\
\hline Es: & 36 & 283326 & 302604 & 119 & 39.87 & 1.33 & -9.76 \\
\hline ORIE & 65 & 849 & 16 & 082 & -7.77 & 54.00 & 35.32 \\
\hline "TIGR & 109 & 44632 & 66 & 392 & 22.06 & 8.26 & 7.11 \\
\hline Itáli & 380 & 38711 & 36 & 92 & -2.01 & -1.07 & 16.13 \\
\hline C: & 307 & 206 & 107946 & 602 & 34.71 & -2.13 & -0.72 \\
\hline Ci & 10 & 01 & 14 & 189 & 27.21 & 13.41 & 6.62 \\
\hline URSS (formal) & 47 & 209962 & 67 & 370 & -22.94 & -20.29 & -0.68 \\
\hline EFT & & 80876 & 62 & 68994 & 4.04 & -6.06 & -0.80 \\
\hline ́́cia & 99 & 61369 & 03 & 37670 & 4.94 & -7.39 & -1.61 \\
\hline C & 57 & 16393 & 69 & 28 & -2.80 & 29.60 & -6.72 \\
\hline Din & 47 & 33639 & 7062 & 32162 & -8.10 & -26.79 & 24.20 \\
\hline nido & 76 & 69661 & 19420 & 31441 & 108.19 & -20.10 & 7.13 \\
\hline Ho & 2800 & 6344 & 8170 & 30412 & 17.64 & 8.86 & 20.66 \\
\hline Po & 160 & 10207 & 73081 & 27742 & 182.74 & 48.25 & -12.92 \\
\hline ÁFR & 35722 & 72996 & 23622 & 22162 & 19.66 & -20.20 & -0.91 \\
\hline juai & 40 & 3434 & 6317 & 31 & 10.06 & 9.14 & 16.22 \\
\hline & 1685 & 7621 & 21616 & 14769 & 48.07 & 23.18 & -6.30 \\
\hline $\mathbf{F i}$ & 2671 & 4423 & 8030 & 8917 & 13.44 & 12.67 & 1.61 \\
\hline St & 319 & 4629 & 6607 & 8825 & 94.17 & 3.99 & 6.97 \\
\hline OCEANIA & 1 & 167 & 2440 & 3707 & 219.62 & 73.21 & 6.16 \\
\hline ga & 16412 & 10626 & 6682 & 2413 & -9.09 & -8.96 & -13.36 \\
\hline & 883 & 6862 & 4642 & 1718 & -3.94 & -4.97 & -12.97 \\
\hline & 13 & 30 & 486 & 1269 & 21.76 & 74.92 & 14.71 \\
\hline
\end{tabular}

Fonte: FAO.

Obs: Os dados estão ordenados segundo a importância do mercado exportador, com base no período 1989/90/91. 


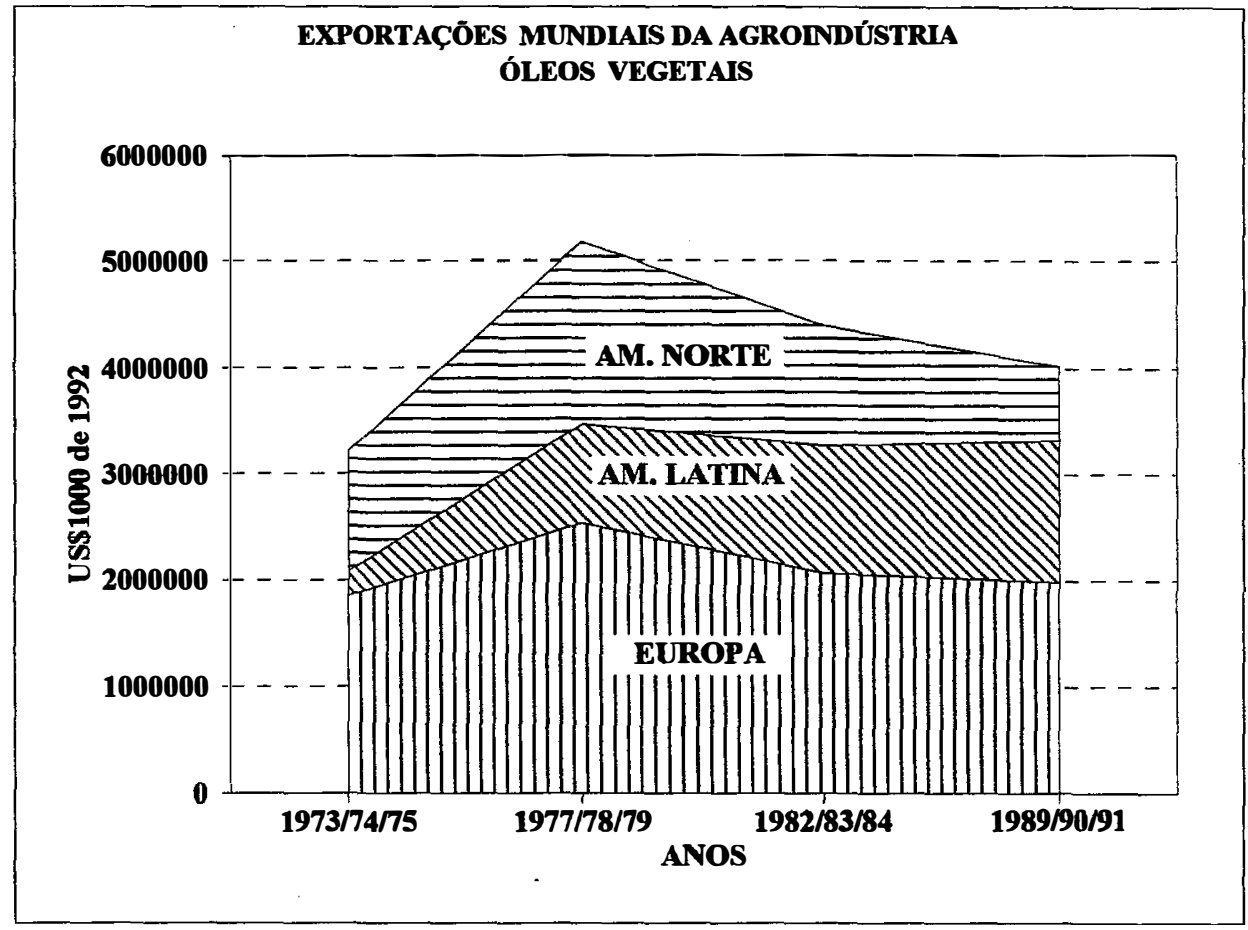

(a)

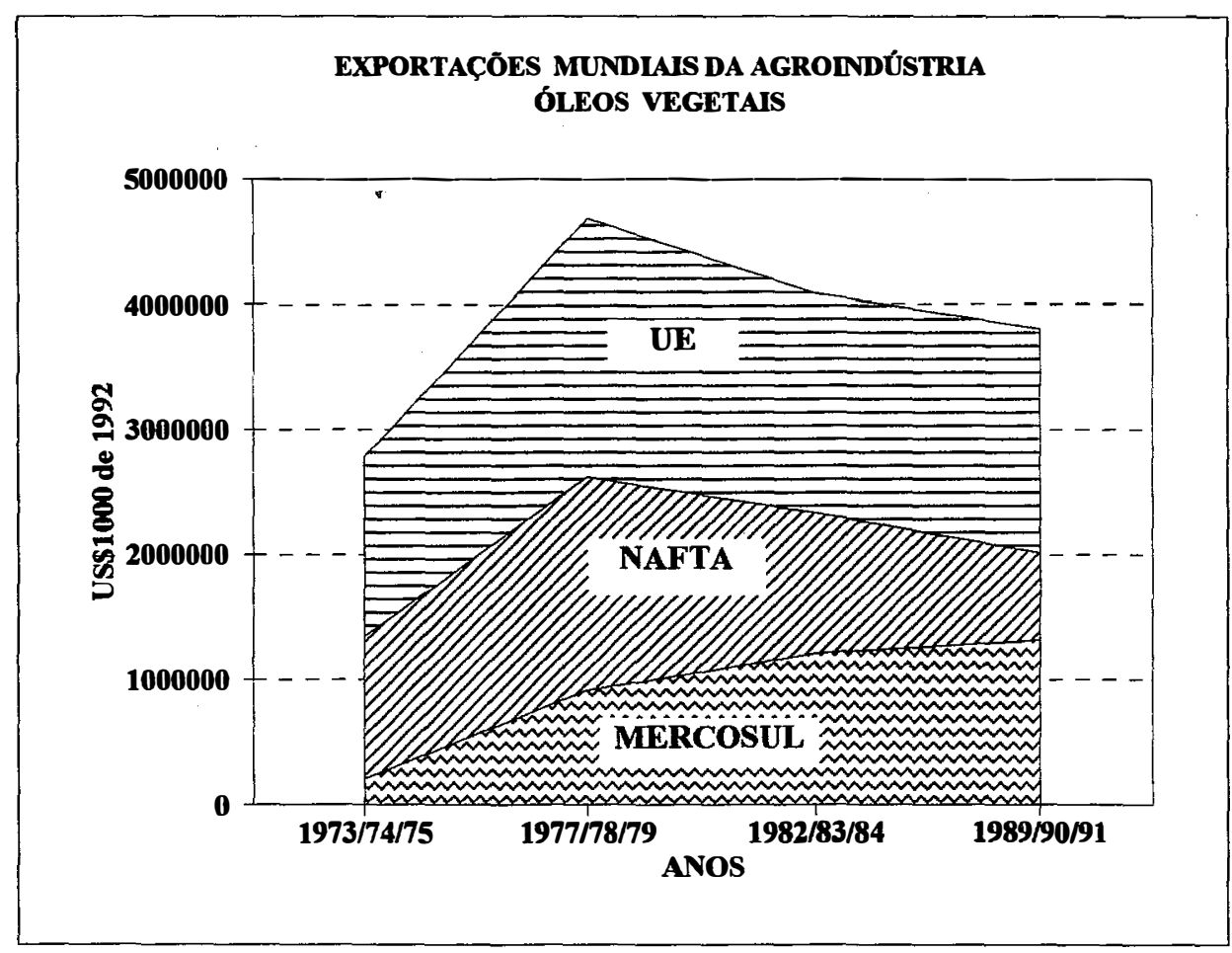

(b)

Figura 14 - Óleos vegetais - evolução das exportações mundiais das principais. regiōes (a) e blocos económicos (b) 
mundial exportado. Essa posição de destaque é basicamente devida às exportações de óleo de soja. No total mundial, a América Latina ocupa uma parcela de $43,8 \%$, sendo a Argentina $(57,0 \%)$ e o Brasil $(40,2 \%)$ os principais exportadores. No entanto, nos anos mais recentes, as exportações de óleo de soja da América Latina estão estagnadas, o que, parcialmente, reflete 0 comportamento das exportações brasileiras, que passam por uma fase de decréscimo.

As exportações de óleo de girassol e de algodão são menos importantes, com relação ao valor, no grupo dos óleos, participando com $29,0 \%$ e $3,2 \%$, respectivamente, enquanto só o óleo de soja representa $40,0 \%$ do total exportado. A América Latina ocupa também a segunda posição, com uma participação de $39,0 \%$ das exportações de óleo de girassol, sendo a Argentina o principal pais exportador $(97,9 \%)$. No caso do óleo de algodão, a participação desta região é de $42,9 \%$, sendo o Brasil, principal exportador $(55,1 \%)$ seguido pela Argentina $(36,7 \%)$.

O mercado exportador europeu tem grande importância nas exportações de óleo de soja, $34,1 \%$, dos quais a UE detém uma parcela de $96,7 \%$. No entanto, em termos de dinâmica ao longo do tempo, observa-se uma gradativa perda de espaço, revelada pelos valores negativos das taxas geométricas de crescimento, nos últimos periodos analisados.

Nas exportações de óleo de girassol e de colza, a Europa também é principal mercado exportador, representando $41,7 \%$ e $80,5 \%$ do total exportado no mundo, respectivamente. As taxas geométricas de crescimento revelaram uma dinâmica diferente na evolução das exportações européias desses dois produtos agroindustriais. Enquanto para o óleo de colza observou-se um significativo crescimento médio anual, de meados da década de 80 para o início dos anos 90 $(7,4 \%)$, as exportações de óleo de girassol neste mercado permaneceram praticamente estagnadas. Esse quadro evolutivo é percebido também na medida em que se verifica que a participação das exportações de óleo de colza nas exportações totais de óleo no mercado europeu passou, no referido período, de $23,0 \%$ para $38,0 \%$. Para o óleo de girassol, os respectivos percentuais foram de $24,5 \%$ e $26,0 \%$, ou seja, o ritmo de crescimento das exportações de óleo de colza tem sido bem superior ao de girassol. 
As exportações de óleo de algodão e de milho estão basicamente concentradas nos EUA, cuja parcela de mercado é respectivamente $50,7 \%$ e $40,0 \%$ do total exportado. Em termos de participação no comércio externo total de óleos, no entanto, esses produtos têm participações relativamente inexpressivas, ou seja, de $3,2 \%$ e $7,5 \%$, respectivamente. 0 mercado europeu é o segundo exportador de óleo de milho com $30,0 \%$ do total, montante basicamente proveniente da UE $(97,2 \%)$.

\section{Farelos e Tortas}

Apesar de este grupo ser composto por quatro subprodutos, o farelo de soja é o principal componente representando $88,2 \%$ do total exportado, ficando os demais, torta de colza $(5,7 \%)$, de girassol $(3,7 \%)$ e de algodão $(2,3 \%)$, com percentuais de participação relativamente inexpressivos.

O principal exportador mundial deste grupo de produtos é a América Latina (47,4\%), devido às exportações do MERCOSUL (98,9\%), cujos principais países são Brasil $(59,1 \%)$ e Argentina (28,2\%) (Tabela 12 e Figura 15). A posição de liderança da América Latina dá-se basicamente pelas exportações de farelo de soja $(50,4 \%)$, sendo o Brasil responsável por uma parcela de $62,1 \%$ do total exportado por este mercado, seguindo-se a Argentina, com participação bem menor $(24,0 \%)$. No entanto, as exportações brasileiras de farelo de soja, que tiveram seu auge na década de $70 \mathrm{com}$ a instalação do parque moageiro, vêm decrescendo gradativamente desde o final dessa década e o início dos anos 80. 0 contrário está ocorrendo na Argentina, onde as taxas geométricas anuais de crescimento das exportações de farelo de soja têm apresentado valores crescentes e relativamente altos.

Também nas exportações de torta de girassol, a América Latina ocupa a primeira posição, com um percentual de $63,5 \%$, parcela que, na verdade, representa as exportações da Argentina (99,3\%), onde as taxas de crescimento sinalizam um mercado em expansão.

As exportações de torta de colza, ainda que com participação pequena no grupo, merecem menção pelas taxas de crescimento altas e positivas 
Tabela 12 - Exportações mundiais de farelos e tortas (soja, colza, girassol e algodão), 1000US\$ FOB de 1992) e taxas geométricas médias anuais de crescimento entre os produtos

\begin{tabular}{|c|c|c|c|c|c|c|c|}
\hline REG|ÅO/PAÍs & $1973 / 74 / 76$ & $1977 / 78 / 79$ & $1982 / 83 / 84$ & 1989/90/91 & $\%$ & $\%$ & $\%$ \\
\hline & a & b & $\mathbf{c}$ & d & $\mathbf{b} / \mathbf{a}$ & $\mathbf{c / b}$ & $d / c$ \\
\hline MUNDO & 4371616 & 6381968 & 6818258 & 6182869 & 9.92 & -1.83 & 0.87 \\
\hline AMÉRICA LATINA & 1077919 & 2462272 & 2439623 & 2932074 & 22.81 & -0.10 & 2.66 \\
\hline MERCOSUL & 1031449 & 2416776 & 2426052 & 2900716 & 23.71 & 0.08 & 2.69 \\
\hline Brasil & 912665 & 2116647 & 1911176 & 1716936 & 23.39 & -2.01 & -1.63 \\
\hline EUROPA & 1069082 & 1323605 & 1480314 & 1247738 & 6.48 & 2.26 & -2.41 \\
\hline UE & 996780 & 1262268 & 1424802 & 1167661 & 6.08 & 2.46 & -2.92 \\
\hline NAFTA & 1940660 & 2364944 & 1689024 & 1144117 & 4.96 & -7.67 & -4.68 \\
\hline Estados Unidos & 1897177 & 2297433 & 1546694 & 1072191 & 4.90 & -7.62 & -6.09 \\
\hline ÁSIA & 198841 & 189685 & 282058 & 832310 & -1.18 & 8.27 & 16.72 \\
\hline Argentina & 102727 & 284122 & 601692 & 818917 & 28.96 & 12.04 & 7.26 \\
\hline China & 4949 & 7268 & 167602 & 626366 & 10.06 & 85.06 & 18.81 \\
\hline Holanda & 266131 & 621918 & 495969 & 513026 & 18.34 & -1.02 & 0.48 \\
\hline Alemanha & 476162 & 373247 & 362690 & 304667 & -6.91 & -0.68 & -2.46 \\
\hline Bel-Lux & 92706 & 220626 & 313201 & 242726 & 24.20 & 7.26 & -3.68 \\
\hline Canadá & 43442 & 67611 & 43430 & 71924 & 7.27 & -6.46 & 7.47 \\
\hline EFTA & 64288 & 62994 & 42967 & 31162 & -4.72 & -4.11 & -4.49 \\
\hline Noruega & 64022 & 62064 & 40768 & 30706 & -6.04 & -4.77 & -3.97 \\
\hline Franca & 40940 & 63316 & 29470 & 25081 & 6.83 & -11.18 & -2.28 \\
\hline Portugal & 1251 & 4340 & 29312 & 24439 & 36.46 & 46.63 & -2.66 \\
\hline ÁFRICA & 78399 & 69490 & 23876 & 23905 & -6.67 & -16.69 & 0.02 \\
\hline Itália & 30003 & 6916 & 34920 & 20637 & -30.71 & 38.25 & -7.30 \\
\hline Paraguai & 14366 & 10733 & 12647 & 19431 & -7.01 & 3.17 & 6.46 \\
\hline Reino Unido & 21674 & 28363 & 6832 & 13760 & 6.96 & -27.12 & 13.04 \\
\hline Grécia & 19911 & 21216 & 8902 & 7327 & 1.60 & -16.94 & -2.74 \\
\hline "TIGRES ASIÁTICOS" & 13182 & 66660 & 12903 & 6628 & 43.36 & -26.35 & -9.08 \\
\hline Cingapura & 3969 & 64647 & 11933 & 6066 & 92.66 & -26.21 & -9.21 \\
\hline ORIENTE MÉDIO & 92732 & 19447 & 2874 & 3642 & -32.33 & -31.78 & 3.44 \\
\hline Espanha & 67 & 127 & 142687 & 2849 & 17.24 & 307.18 & -42.83 \\
\hline Uruguai & 1711 & 6373 & 738 & 2344 & 33.11 & -32.77 & 17.96 \\
\hline URSS (formal) & 6764 & 2032 & 3168 & 2086 & -26.96 & 9.29 & -6.80 \\
\hline Dinamarca & 47422 & 31205 & 1264 & 1946 & -9.93 & -47.33 & 6.36 \\
\hline Irlanda & 611 & 996 & 666 & 1413 & 18.11 & -7.73 & 11.36 \\
\hline Japão & 9223 & 381 & 970 & 209 & -64.91 & 20.64 & -19.72 \\
\hline Tailândia & 4122 & 2463 & 2048 & 20 & -12.08 & -3.62 & -48.26 \\
\hline
\end{tabular}

Fonte: FAO.

Obs: Os dados estão ordenados segundo a importância do mercado exportador, com base no periodo 1989/90/91. 


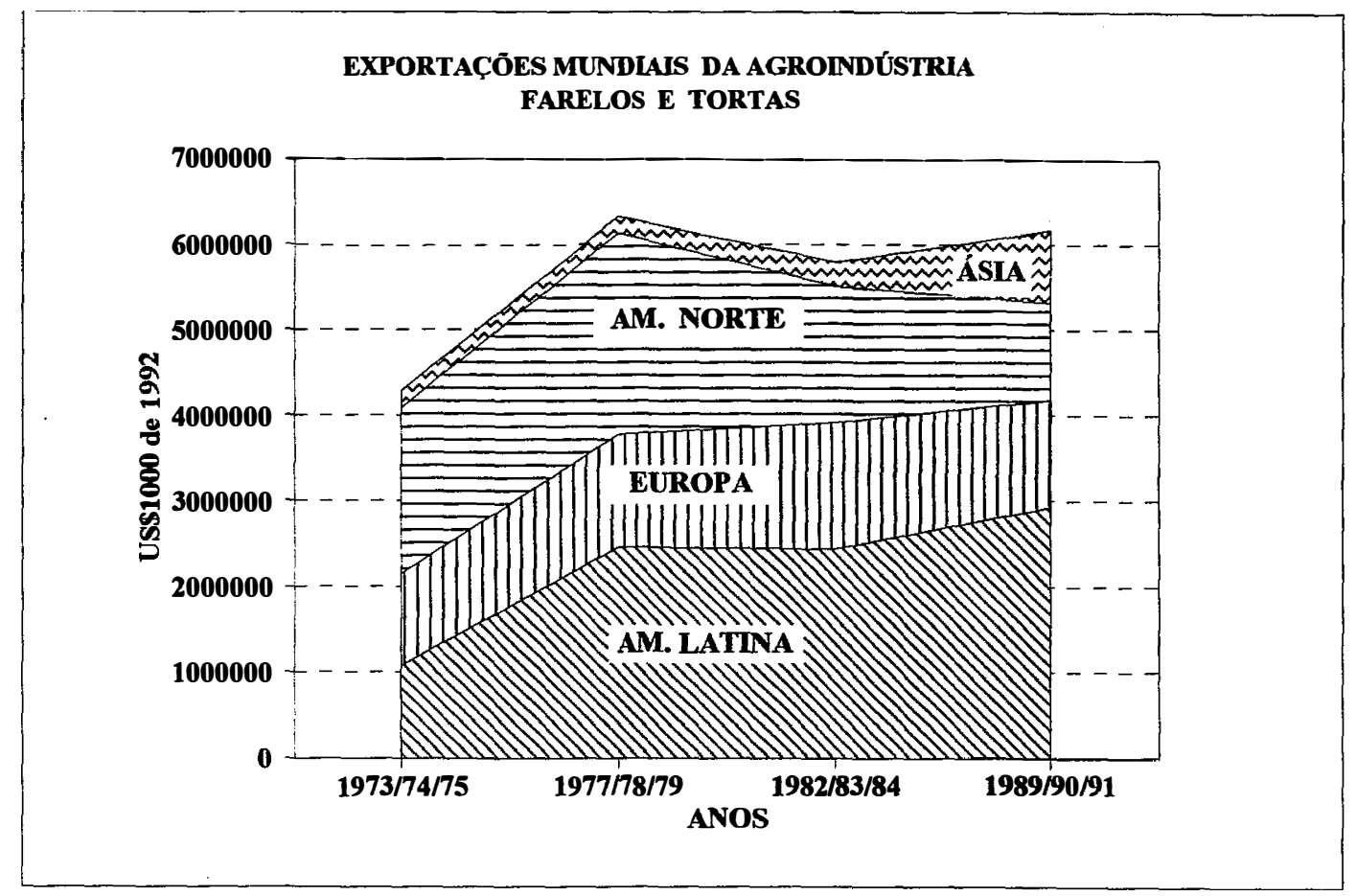

(a)

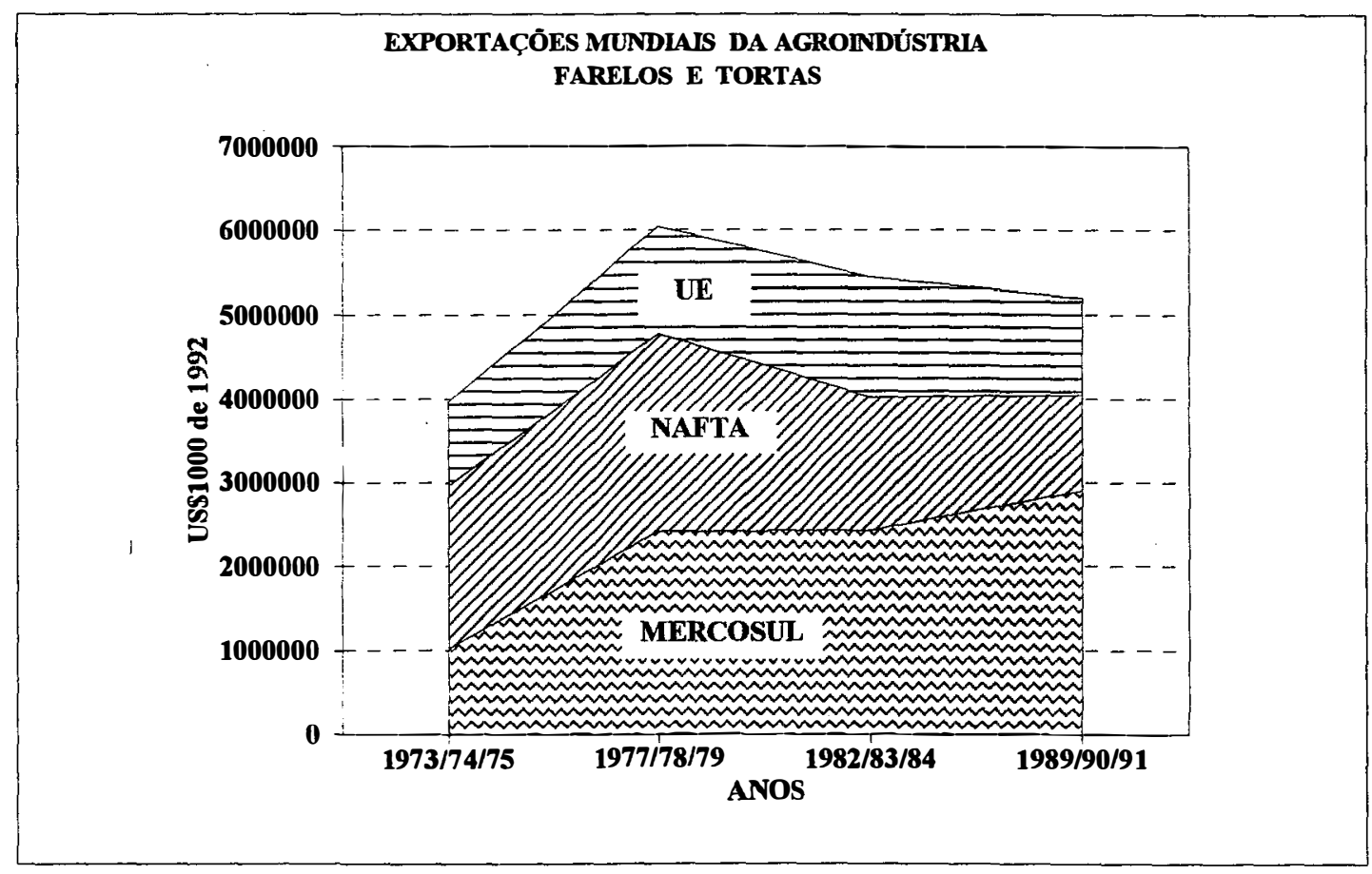

(b)

Figura 15 - Farelos e tortas - evolução das exportações mundiais das principais regiōes (a) e blocos econômicos (b) 
alcançadas nos últimos períodos analisados. O mercado europeu concentra 52,4\% das exportações mundiais, com $77,3 \%$ provenientes da UE. Os paises asiáticos, embora com participação menor nas exportações de torta de colza $(27,0 \%)$, ganham importância em termos evolutivos também pelas altas taxas de crescimento de suas exportações desde meados da década de 70 .

Resultado importante a ser ressaltado, ainda com relação ao mercado asiático, é sua posição de liderança nas exportações de torta de algodão $(51,6 \%)$. Isso significa uma recuperação de espaço no mercado internacional, uma vez que este produto apresentou, de meados da década de 80 para o início dos anos 90, taxa de crescimento positiva e relativamente alta, ao contrário de periodos anteriores em que a queda dessas exportações foi bastante significativa.

\section{Demais Produtos}

Os produtos e subprodutos comercializados no mercado internacional que não se enquadram nos quatro grupos anteriores são analisados neste item e compõem os seguintes complexos agroindustriais: carne, leite, café, açúcar, cacau, algodão, madeira, laranja, fumo, pimenta e peixe.

O mercado europeu, com a quase totalidade das exportações concentradas na UE, é o principal exportador mundial de leite e todos os seus derivados. Não só os percentuais de participação deste mercado nas exportações mundiais de leite fresco $(94,2 \%)$, em pó $(75,7 \%)$ e concentrado $(90,3 \%)$, mas também as taxas geométricas de crescimento positivas nos periodos analisados revelam o completo domínio e a expansão do mercado europeu nas exportações deste complexo agroindustrial.

No mercado exportador de carnes, a situação é semelhante, uma vez que também o mercado europeu detém, respectivamente, $60,5 \%, 92,5 \%$, $68,7 \%$ e $51,9 \%$ das exportações mundiais de carne fresca, seca, preparada e de peles e couros, sendo também um mercado em expansão. No caso da carne preparada (industrializada), a América Latina representa uma parcela de $13,2 \%$ devido às exportações do MERCOSUL (98,9\%), mais especificamente da Argentina $(59,7 \%)$ e Brasil $(34,5 \%)$. Situação semelhante ocorre no mercado 
exportador de peles e couros, no qual a América Latina detém $11,2 \%$, sendo $89,6 \%$ correspondentes ao MERCOSUL, onde destacam a Argentina $(48,4 \%)$ e o Brasil (35,7\%). No entanto, a irregularidade das taxas geométricas de crescimento correspondentes aos periodos analisados dificulta o delineamento de uma tendência nestes mercados secundários. É importante mencionar a participação das exportações de peles e couros no mercado asiático $(24,2 \%)$ e as altas taxas de crescimento apresentadas nos periodos regulares analisados, excetuando o periodo recessivo mundial.

$\mathrm{Na}$ análise dos complexos café, açúcar, cacau e algodão, os resultados revelaram um aspecto interessante, ainda que apenas confirmador de tendências já observadas no comércio mundial dos paises industrializados. As exportações dos subprodutos desses complexos de maior agregação de valor estão concentradas no mercado europeu: café solúvel $(56,1 \%)$, açúcar refinado $(70,3 \%)$, cacau em pó $(67,1 \%)$, pasta de cacau $(42,9 \%)$, manteiga de cacau $(53,1 \%)$, fios de algodão $(58,6 \%)$, e tecidos $(52,0 \%)$. Vale destacar também as exportações de fios de algodão e tecidos dos paises asiáticos, pelas significativas participaçōes nas exportações mundiais: respectivamente $28,0 \%$ e $39,2 \%$. Ademais, são importantes as taxas de crescimento positivas alcançadas, especialmente nos últimos períodos analisados.

Dos complexos citados, as exportações de produtos brutos ou com menor grau de elaboração são provenientes de paises e, ou, regiões menos desenvolvidos. Por exemplo, as exportações de café em grão e açúcar bruto estão concentradas na América Latina $(57,0 \%$ e $65,1 \%$, respectivamente) e de cacau em grão em paises africanos (67,1\%). Mas essas exportações apresentaram tendências declinantes no mercado mundial em todo o período analisado. $O$ algodão bruto tem suas exportações menos concentradas qưanto ao mercado de origem: EUA (30,0\%), Ásia $(20,4 \%)$ e África $(16,2 \%)$.

Apesar de os dados analisados para o Brasil revelarem uma tendência de participação cada vez maior das exportações brasileiras de produtos com maior valor adicionado, tal não ocorre no caso desses três complexos agroindustriais especificos, cujas taxas de crescimento são sempre negativas para todos os produtos e subprodutos. Preços internacionais desestimuladores, nãoincorporação de mudanças tecnológicas na produção e no processamento de 
produtos, entre outros fatores, resultaram em perda de competitividade brasileira, e por consequência, de parcelas de mercado.

O mercado norte-americano tem uma participação significativa nas exportações de pasta química de madeira (55,0\%), provenientes basicamente do Canadá $(57,6 \%)$ e dos EUA (42,2\%). Trata-se de um mercado disputado também pela Europa, que detém uma parcela de $35,0 \%$ do total mundial, sendo a Suécia o principal exportador da UE. O Brasil, embora ocupe uma posição pouco expressiva neste comércio mundial $(3,6 \%)$, apresentou, em todos os períodos analisados, taxas geométricas de crescimento extremamente altas, enquanto os demais mercados tiveram seus valores exportados decrescentes, só entrando em processo de recuperação, com taxas de crescimento positivas, de meados de 1980 ao início dos anos 90.

Com um percentual de participação também pouco expressivo em relação ao comercializado no mundo, estão as exportações brasileiras de papel $(1,5 \%)$, mas, à semelhança do que vem ocorrendo com as exportações de pasta química, é um mercado em expansão, a julgar pelas altas taxas de crescimento observadas desde meados da década de 70. Os demais mercados exportadores, Europa $(67,2 \%)$ e o norte-americano $(24,2 \%)$, à exceção do periodo de recessão mundial, apresentaram taxas de crescimento positivas, porém bem inferiores às atingidas pelo Brasil.

Outro mercado em expansão no Brasil, desde meados da década de 70 , é o de suco de laranja concentrado congelado, cujas taxas anuais de crescimento foram de $14,3 \%$, de meados de 1970 para 1980 , e de 2,2\% deste periodo até o início dos anos 90 . Quanto à participação, o Brasil ocupa a primeira posição do mercado internacional, tendo conquistado uma parcela de $57,5 \%$ do total comercializado no mundo. Com percentual bem inferior, concorrem a UE $(17,7 \%)$ e os Estados Unidos (9,0\%). Na verdade, as exportações de suco de laranja pelos Estados Unidos apresentam-se em posição inferior em relação à UE devido às reexportações deste mercado.

É principalmente nesses produtos especificos, como pasta química de madeira, papel e suco de laranja, que o País tem conseguido maior dinamismo via processo de inovação tecnológica que impulsionou alguns setores da agroindústria, ganhando competitividade internacional e conseqüentemente, maior 
espaço no mercado externo. Tal tendência já foi identificada na análise especifica sobre as exportações brasileiras.

As exportações de fumo estão relativamente distribuidas entre os mercados norte-americano (30,3\%), basicamente EUA (93,8\%); na Europa (20,8\%), com 70,0\% provenientes da UE; na Ásia (19,0\%) e na América Latina $(17,0 \%)$. O que se observa de importante nessa análise é que, excetuando a UE, os demais mercados exportadores de fumo apresentaram taxas de crescimento negativas nos últimos periodos. O Brasil, ao contrário, com a participação de $11,8 \%$ do total mundial nas exportações de fumo, é um mercado com certo dinamismo, revelado pelas taxas geométricas de crescimento positivas em todos os periodos analisados. Com relação às exportações de pimenta, o Brasil tem uma participação no mercado mundial em nivel semelhante à do fumo, de $11,1 \%$, mas vem perdendo sistematicamente parcela de mercado, que já chegou a $21,0 \% \mathrm{em}$ meados da década de 80 . O mercado externo de pimenta é dominado pelas exportações dos paises asiáticos, que detêm $74,7 \%$ do comercializado em nivel mundial.

Finalmente, as exportações mundiais de peixes frescos e congelados estão relativamente concentradas na Europa (45,3\%), sendo 60,0\% a participação dos paises da UE e $40,0 \%$ a do EFTA. O mercado norte- americano representa $23,5 \%$, com $56,6 \%$ das exportações provenientes dos EUA e $41,0 \%$ do Canadá. A Ásia aparece como terceiro mercado continental exportador, com uma participação de $16,6 \%$ do comércio internacional. Em termos evolutivos, todos os mercados citados apresentam taxas de crescimento positivas (exceto no periodo recessivo) e relativamente altas, revelando assim uma tendência geral expansionista.

Em sintese, essa análise revela que o mercado europeu e o norteamericano, mais especificamente a UE e os EUA, são os principais atores do comércio mundial de produtos da agroindústria.

A despeito da guerra comercial que se vem travando, nas últimas décadas, pela conquista de parcelas de mercado, os dados confirmam o domínio dessas regiões em distintos setores do comércio mundial. 
Para os cereais e grãos oleaginosos, principais agrupamentos de produtos agrícolas e de importância estratégica, o mercado norte-americano é o principal exportador, além de dominar o mercado externo de outros produtos, como da pasta química de madeira e do fumo.

No entanto, a relativa queda das exportações americanas nos anos mais recentes é um sintoma da gradativa diminuição do domínio dos excedentes exportáveis agroindustriais pelos EUA.

Em contrapartida, é notável a crescente participação da UE nas exportações mundiais da agroindústria. É o principal bloco exportador de óleos vegetais, mantendo também o domínio do comércio mundial de leite, carnes e seus derivados. Os subprodutos com maior grau de industrialização dos complexos café, açucar, cacau, algodão e madeira vêm ocupando também posição de destaque, com tendência de crescimento.

As políticas de subsídio à produção e de incentivo às exportações, além da variação do dólar na primeira metade dos anos 80 , que possibilitaram uma atuação mais competitiva das exportações européias em relação às americanas são fatores explicativos desse novo cenário do mercado mundial.

A queda das exportações de produtos brutos da América Latina e o incremento relativo dessa região no comércio mundial de produtos mais elaborados são também tendências mais recentes. Nesse contexto, destaca-se a posição do Brasil pela predominância do mesmo fenômeno, que, ocorre, entretanto, de forma mais acentuada. A pasta química de madeira, o papel, o suco de laranja, e alguns tipos de óleo são os produtos que estão liderando esse processo de transformação na economia brasileira. 


\section{FONTES DE CRESCIMENTO DAS EXPORTAÇŌES DA AGROINDÚSTRIA BRASILEIRA}

\subsection{REFERENCIAL TEÓRICO}

Neste capitulo, discute-se o referencial teórico que permite a determinação dos fatores que tiveram influência no desempenho das exportações dos produtos da agroindústria brasileira ao longo das últimas décadas.

Tomou-se como referência o modelo de Constant-Market-Share (CMS), aplicado a várias análises do comportamento das exportações, como em STERN (1967); BROWN (1969); LEAMER \& STERN (1970) e TYLER (1976). No Brasil, HORTA (1983); GONÇALVES (1987); HORTA et alii (1993); ALMEIDA (1993), entre outros, utilizaram o CMS em estudos sobre o comportamento das exportações de produtos manufaturados:

Em linhas gerais, o método atribui o crescimento favorável ou desfavorável do setor exportador tanto à estrutura das exportações do país quanto à sua competitividade. A pressuposição do modelo é de que o pais em questão mantém constante sua parcela de mercado no comércio mundial, sendo a diferença do crescimento das exportações implícita no modelo e sua efetiva performance atribuida ao efeito competitividade.

Assim, a taxa de crescimento das exportações é decomposta em quatro efeitos:

- crescimento do comércio mundial;

- composição da pauta de exportações; 
- destino das exportações; e

- competitividade.

A análise com base no modelo CMS tem sua importância e interesse na medida em que determina o peso de cada efeito nas exportações do país em questão e mostra a extensão para a qual estas se direcionam para mercadorias e, ou, mercados com maior potencial de expansão. Nesse sentido, os resultados poderiam indicar alternativas de atuação e sinalizar caminhos de distribuição das exportações, de forma a se perseguirem "market-shares" de maior dinamismo. Embora o método tenha um caráter retrospectivo, há possibilidades de se fazerem inferências sobre o direcionamento do setor exportador, para mercados mais favoráveis, e sobre a concentração em mercadorias com perspectivas mais dinâmicas, sob a pressuposição de continuidade das tendências observadas nesses mercados.

\section{O MODELO CMS}

A forma mais simples do modelo CMS define a parcela de mercado (S) de um país $A$ como função de sua competitividade relativa ${ }^{1}$ :

$$
S \equiv \frac{q}{Q}=\mathrm{f}\left(\frac{\mathrm{c}}{\mathrm{C}}\right) \quad \mathrm{f}^{\prime}(\mathrm{l})>0
$$

em que:

$\mathrm{q}, \mathrm{Q}=$ quantidades exportadas totais do país $\mathrm{A}$ e do mundo, respectivamente;

C,$C=$ competitividade do pais $A$ e do mundo, respectivamente.

\footnotetext{
${ }^{1}$ O desenvolvimento do modelo está baseado em RICHARDSON, J.D. (1970) e LEAMER \& STERN (1970).
} 
Rearranjando os termos e derivando em relação ao tempo, tem-se:

$$
\begin{aligned}
& \frac{d q}{d t} \equiv \mathrm{S} \frac{\mathrm{dQ}}{\mathrm{dt}}+\mathrm{Q} \frac{\mathrm{dS}}{\mathrm{dt}} \\
& \dot{q} \equiv S \dot{Q}+\mathrm{Q} \dot{\mathrm{S}} \\
& \dot{q} \equiv \mathrm{S} \dot{\mathrm{Q}}+\mathrm{Q} \mathrm{f}^{\prime}\left(\frac{d\left(\frac{c}{C}\right)}{d t}\right) \\
& \dot{q} \equiv \mathrm{SQ}+\mathrm{Q}^{\prime}\left(\frac{\dot{c}}{C}\right)
\end{aligned}
$$

A variação total na quantidade exportada pelo país A $(\dot{q})$ é explicada por um efeito crescimento das exportações mundiais ( $\left.\mathrm{SQ}_{\mathbf{Q}}\right)$ e um efeito competitividade $(\dot{S} Q)$. O primeiro representa a variação ocorrida desde que mantida constante a parcela de mercado, e o segundo, o crescimento adicional causado pelas mudanças na competitividade relativa.

Um modelo CMS mais complexo leva em consideração a estrutura das exportações do país, que, mesmo na ausência de mudanças na competitividade relativa, pode estar afetando o comportamento das exportações ao longo dos anos. As exportações podem estar concentradas em mercadorias cuja demanda está crescendo mais rapidamente ou destinando-se prioritariamente a regiōes de crescimento mais dinâmico e vice-versa.

Dessa forma, a identidade (1) ficaria: 


$$
S_{i j} \equiv \frac{q_{i j}}{Q_{i j}}=\mathrm{f}_{\mathrm{ij}}\left(\frac{c_{i j}}{C_{i j}}\right), \quad \mathrm{f}_{\mathrm{ij}}^{\prime}>0
$$

sendo:

$$
\begin{aligned}
& \text { i = mercadoria; } \\
& \text { j = mercado de destino }
\end{aligned}
$$

O crescimento total das exportações passa a ser dado pela expressão:

$$
\dot{q} \equiv \sum_{i} \sum_{j} S_{i j} \dot{\mathrm{Q}}_{\mathrm{ij}}+\sum_{i} \sum_{j} Q_{i j} \dot{\mathrm{S}}_{\mathrm{ij}}
$$

que, expandindo, toma-se:

$$
\dot{q} \equiv S \dot{Q}+\left[\sum_{\mathrm{i}} \mathrm{S}_{\mathrm{i}} \dot{\mathrm{Q}}_{\mathrm{i}}-\mathrm{S} \dot{\mathrm{Q}}\right]+\left[\sum_{\mathrm{i}} \sum_{\mathrm{j}} \mathrm{S}_{\mathrm{ij}} \dot{\mathrm{Q}}_{\mathrm{ij}}-\sum_{\mathrm{i}} S_{i} \dot{\mathrm{Q}}_{\mathrm{i}}\right]+\sum \sum \mathrm{Q}_{\mathrm{ij}} \dot{\mathrm{S}}_{\mathrm{ij}}
$$

(a)

(b)

(c)

(d)

Os termos (b) e (c) representam, respectivamente, o efeito mercadoria e o efeito mercado. Esses efeitos são discutidos, a seguir, na formulação especifica do modelo CMS, usada neste trabalho, que considera como variável básica o valor das exportações e as estimativas referem-se a pontos discretos no tempo.

Partindo do modelo básico, com exportações não-diferenciadas por mercadorias e regiões, tem-se a identidade:

$$
V^{*} . .-V_{. .} \equiv r V_{. .}+\left(V^{*} . .-V_{. .}-r V_{. .}\right)
$$


em que:

V.. = valor total das exportações do pais $A$, periodo 1 ;

$V^{*} .$. = valor total das exportações do pais $\mathrm{A}$, periodo 2 ;

$\mathbf{r} \quad$ = incremento das exportações mundiais do periodo 1 para o periodo 2.

A variação das exportações do pais $A$ de um periodo a outro, está associada à variação das exportações mundiais (a) e a um efeito residual atribuido à competitividade (b).

Como as exportações compõem-se de um conjunto diverso de mercadorias tem-se para a i-ésima mercadoria uma expressão análoga à (4):

$$
V_{i,-}^{*} V_{i,} \equiv r_{i} V_{i_{0}}+\left(V_{i,}^{*}-V_{i},-r_{i} V_{i}\right)
$$

em que:

$$
\begin{aligned}
V_{i .}= & \text { valor das exportações da mercadoria } i \text { do pais } A \text {, periodo } 1 ; \\
V_{i \cdot}^{*}= & \text { valor das exportações da mercadoria } i \text { do pais } A \text {, periodo } 2 ; \\
r_{i}= & \text { incremento percentual das exportações mundiais da mercadoria } i \\
& \text { do periodo } 1 \text { para o periodo } 2 .
\end{aligned}
$$

Esta expressão pode ser agrupada em:

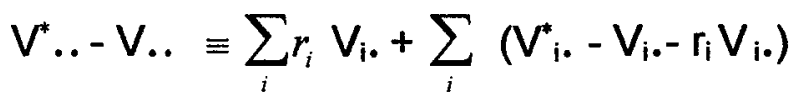

$$
\begin{aligned}
& \equiv\left(r V_{. .}\right)+\sum_{i}\left(r_{i}-r\right) V_{i \cdot}+\sum_{i}\left(V_{i \cdot}^{*}-V_{i_{\bullet}}-r_{i} V_{i_{\bullet}}\right)
\end{aligned}
$$

Finalmente, considerando a diferenciação das exportações também por destino, chega-se à equação de CMS para um tipo particular de mercadoria e uma região particular de destino:

$$
V_{i j}^{*}-V_{i j} \equiv r_{i j} V_{i j}+\left(V_{i j}^{*}-V_{i j}-r_{i j} V_{i j}\right)
$$


em que:

$V_{i j}=$ valor das exportações da mercadoria $i$ do pais $A$ para 0 pais $j$, periodo1;

$\mathrm{V}_{\mathrm{ij}}^{*}=$ valor das exportações da mercadoria $\mathrm{i}$ do pais $\mathrm{A}$ para 0 pais $\mathrm{j}$, periodo2;

$r_{i j}=$ incremento percentual das exportações mundiais da mercadoria i para o pais j do periodo 1 para o periodo 2.

Da mesma forma, esta equação pode ser agrupada em:

$$
\begin{aligned}
& V . .-V_{.} \equiv \sum_{i} \sum_{j} r_{i j} V_{i j}+\sum_{i} \sum_{j}\left(V_{i j}^{*}-V_{i j}-r_{i j} V_{i j}\right) \\
& \quad \equiv r . .+\sum_{i}\left(r_{i}-r\right) V_{i} \cdot+\sum_{i} \sum_{j}\left(r_{i j}-r_{i}\right) V_{i j}+\sum_{i} \sum_{j}\left(V_{i j}^{*}-V_{i j}-r_{i j} V_{i j}\right)
\end{aligned}
$$

(a)

(b) (c) (d)

Essa identidade permite decompor a taxa de crescimento das exportações do pais $\mathrm{A}$ em quatro efeitos. Os dois primeiros estão relacionados com fatores externos e os dois últimos refletem a influência de fatores internos:

(a). efeito crescimento do comércio mundial: incremento observado se as exportações do pais $A$ tiverem crescido à mesma taxa de crescimento do comércio mundial;

(b). efeito composição da pauta: mudanças na estrutura da pauta com concentração em mercadorias com crescimento de demanda mais ou menos acelerado;

(c). efeito destino das exportações: mudanças decorrentes das exportações de mercadorias para mercados de crescimento mais ou menos dinâmicos; $e$

(d). efeito residual, representando competitividade.

Os efeitos composição da pauta (b) e destino das exportações (c) requerem uma interpretação adicional. 
Para o efeito composição da pauta:

$$
\sum_{i}\left(r_{i}-r\right) \mathrm{V}_{\mathrm{i}}
$$

se as exportações mundiais da mercadoria $i$ aumentarem mais que a média mundial para todas as mercadorias exportadas, $\left(r_{i}-r\right)$ é positiva e tomará forte esse efeito se $V_{i}$. for relativamente grande, ou seja, o efeito composição da pauta será positivo se as exportações do país $A$ estiverem concentradas em mercadorias de maior expansão ou quando a taxa de crescimento for superior à média mundial.

De forma análoga, o efeito destino das exportações:

$$
\sum_{i} \sum_{j}\left(r_{i j}-r_{i}\right) V_{i j}
$$

será positivo se o pais A tiver concentrado suas exportações em mercados que experimentaram maior dinamismo no periodo analisado e negativo se concentrado em regiões mais estagnadas.

\section{O EFEITO COMPETITIVIDADE}

A diferença entre o crescimento das exportações na formulação do modelo CMS e o crescimento efetivo das exportações é atribuída ao efeito competitividade. A medida deste efeito residual está, na prática, relacionada com mudanças nos preços relativos, ou seja, os importadores tendem a substituir o consumo dos bens cujos preços se elevaram pelo consumo daqueles com preços menores em termos relativos. Assim, quando um pais deixa de manter sua parcela no mercado mundial, o termo competitividade é negativo e indica preços aumentando para o pais em questão, em proporção maior que os preços de seus competidores. 
Se os preços relativos são tomados como medida de competitividade relativa, a relação básica inicial (1) fica associada à elasticidade de substituição, que, num enfoque de comércio internacional, capta a capacidade de uma mercadoria exportada por determinado pais substituir uma mercadoria similar exportada pelo pais concorrente na curva de indiferença do pais importador.

Quando se definem "market-shares" como valor exportado, um efeito competitivo tanto positivo quanto negativo pode ser consistente com a queda dos preços relativos, dependendo do valor absoluto da elasticidade de substituição.

Isso pode ser percebido claramente, a partir da definição empirica da elasticidade de substituição no ponto de maximização da utilidade com restrição orçamentária:

$$
\sigma=\frac{\mathrm{d}\left(\mathrm{q}_{1} / q_{2}\right)}{d\left(p_{1} / p_{2}\right)} \cdot \frac{\mathrm{p}_{1} / p_{2}}{q_{1} / q_{2}}=\frac{\mathrm{d} \log \left(\mathrm{q}_{1} / q_{2}\right)}{d \log \left(\mathrm{p}_{1} / p_{2}\right)}
$$

em que:

$$
\begin{aligned}
& \sigma=\text { elasticidade de substituição; } \\
& q_{1} / q_{2}=\text { relação de quantidades exportadas e } \\
& p_{1} / p_{2}=\text { relação de preços. }
\end{aligned}
$$

Com base nessa definição, um pais ampliaria sua parcela de mercado na medida em que a queda do preço relativo fosse proporcionalmente menor do que o aumento da quantidade relativa comercializada.

Assim, um efeito competitivo positivo consistente com queda de preços relativos requer a pressuposição adicional de que a elasticidade de substituição exceda um em valor absoluto. Para essa categoria de dados, resultados de estimativas de elasticidade de substituição em mercados de exportação têm apresentado, quase sempre, valores consistentes com essa hipótese. Ver por exemplo FONTES \& BARBOSA (1991); SILVA (1992) e MEDEIROS \& TEIXEIRA (1994). 
LEAMER \& STERN (1970) apontam uma distorção na interpretação do termo competitividade. No contexto deste modelo, um pais seria rotulado de "não competitivo" se reduzisse sua participação no comércio mundial. Na verdade, um pais pequeno pode não ter capacidade doméstica de manter sua parcela de mercado em situação de crescimento rápido da demanda do importador e ser classificado como menos competitivo do que outro pais que mantém constante sua parcela de mercado por estar exportando para regiōes relativamente estagnadas.

Outra questão relacionada com a competitividade abordada por RICHARDSON (1971) é o fato de este componente residual estar refletindo o efeito de outros fatores que afetam a capacidade de venda de um país para mercados estrangeiros, como melhoria de qualidade, acordos financeiros, mudanças na política de comércio, padrões de demanda, costumes e preferências. LEAMER \& STERN (1970) adicionam ainda a influência de taxas diferenciais de inflação dos preços de exportação e eficiência de marketing sobre o desempenho das exportações de um pais.

Há, também, a possibilidade de mudanças nos padrões de vantagens comparativas para maior sofisticação na produção de mercadorias exportadas. Nesse caso, alterações na competitividade relativa poderiam estar relacionadas com vantagens especificas ou com fatores locacionais das indústrias processadoras de produtos exportados.

O efeito competitividade envolve, portanto, a interação de diferentes fatores que estão por trás do conceito e sobre o qual não existe, na literatura, um consenso mais rigoroso em termos de definição. HORTA et alii (1993) apresentam três linhas conceituais relacionadas com a competitividade intemacional $(\mathrm{Cl})$ e discutem as dificuldades envolvidas na escolha de um ou outro indicador. $O$ conceito desempenho associa a competitividade do pais diretamente a seu desempenho no mercado intemacional; o conceito macro considera variáveis relacionadas com decisões políticas, como subsídios e taxa de câmbio, e o conceito eficiência reflete características estruturais da economia (aumentos de produtividade). 
Dentre os principais problemas relacionados com esses indicadores de competitividade, estão a impossibilidade de explicitar os fatores explicativos da competitividade (conceito desempenho), a ambigüidade dos resultados obtidos a partir de séries longas de tempo (conceito macro), e a dificuldade de construção de indicadores apropriados (conceito eficiência).

À semelhança das demais análises sobre o comportamentos das exportações a partir do modelo CMS, este trabalho considera o conceito desempenho na análise da competitividade internacional, ou seja, o efeito competitividade é quantificado sem envolver a identificação dos fatores explicativos desse indicador. Isto é feito, na discussão dos resultados a partir da identificação da ocorrência de fatores econômicos internos e externos que se relacionam ao ganho e, ou, perda de competitividade do pais no mercado internacional, no periodo analisado.

\section{ESCOLHA DOS PADRÕES DE ANÁLISE}

A aplicação do modelo CMS requer a definição de alguns padrões que servem de base para a análise do desempenho e da estrutura das exportações do pais considerado.

\section{Mercado de Destino}

Em geral, os estudos nesta área têm considerado o mercado mundial como mercado de destino ou algum subconjunto que represente mais apropriadamente a competição enfrentada pelo pais.

A especificação de um padrão de análise mais representativo da realidade é fundamental na medida em que os resultados são muito sensiveis a esta escolha, podendo ocorrer variações de acordo com uma ou outra definição. RICHARDSON (1971) chega a sugerir a definição de um mercado de destino para cada mercadoria, de acordo com a identidade dos competidores. 
As exportações brasileiras vêm destinando-se, historicamente, para regiões diversificadas, ou seja, o país é considerado um "global trader" por comerciar com todas as grandes regiões do mundo, ainda que com relativa concentração em algumas áreas ${ }^{1}$. Optou-se, então, por considerar os principais mercados continentais, blocos econômicos e, ou, países importadores dos produtos brasileiros, cuja relação cọnsta do Apêndice 5 .

\section{Mercadoria}

As mercadorias selecionadas para análise, outro ponto importante na operacionalização do modelo CMS, foram as mesmas analisadas no Capítulo 2, ou seja, os 13 complexos agroindustriais que representam a quase totalidade das exportações brasileiras: soja, café, madeira, laranja, carne bovina, cacau, açúcar, fumo, algodão, castanha-de-caju, pimenta, frango e pesca.

A decomposição dos principais fatores explicativos do comportamento das exportações é feita numa primeira fase, considerando todos os complexos agroindustriais. Posteriormente, o modelo CMS é aplicado a partir da classificação de cada produto nos grupos dos agregados básicos, semimanufaturados e manufaturados. Assim é possivel determinar diferenças entre os fatores explicativos do comportamento da exportações, ao longo dos anos, entre os complexos agroindustirais e entre os agregados, identificando aspectos relacionados com mudanças de tendência na pauta.

\footnotetext{
${ }^{1}$ A distribuição geográfica das exportações brasileiras está em torno de $30 \%$ para a UE, $20 \%$ para EUA, $15 \%$ para a Ásia Oriental e 15 a 20\% para a América Latina.
} 


\section{Período de Análise}

Finalmente, há a necessidade de se fixarem periodos de análise, uma vez que a aplicação do modelo CMS é realizada entre pontos discretos no tempo. Considerando que a estrutura das exportações mundiais e de um país em particular sofrem mudanças ao longo do tempo, a divisão em subperíodos mais curtos permite identificar, com maior precisão, as mudanças que ocorreram entre o início e o fim da série temporal, especialmente quando a economia passa por freqüentes mudanças que podem afetar de forma diferenciada as exportações.

Neste estudo são considerados quatro subperíodos, cada um representando média de três anos, selecionados de forma a representar alguns momentos importantes para a economia brasileira do início dos anos 70 até os primeiros anos da década de 90 .

Assim, tem-se:

a) $1973 / 74 / 75$ - período inicial, representando a estrutura das exportações brasileiras nos primeiros anos da década de 70;

b) $1977 / 78 / 79$ - segundo período, representando a situação anterior à crise econômica do início dos anos 80 ;

c) 1982/83/84 - terceiro período, representando o desempenho das exportações durante a crise; $e$

d) 1989/90/91/92 ${ }^{1}$ - último período, representando a situação mais recente em que as mudanças na estrutura da pauta de exportações brasileiras tornaram-se mais evidentes.

\footnotetext{
${ }^{1}$ Dada a disponibilidade de dados, neste último período, considerou-se média de 4 anos.
} 


\section{INDICADOR DE VANTAGEM COMPARATIVA REVELADA}

A partir da caracterização do setor agroindustrial brasileiro em que emerge um padrão de inserção no comércio internacional, visando maior diversificação de sua pauta de exportações, torna-se importante verificar como se caracteriza essa nova estrutura, ou seja, em que padrão de especialização internacional está baseada, quanto ao tipo de produto exportado.

Com esse objetivo, procede-se ao cálculo do Indicador de Vantagem Comparativa Revelada (VCR) das exportações $\left(I_{(x)} P i\right)$, definido da seguinte forma ${ }^{1}$ :

$$
\left(I_{(x)} P i\right)=\frac{x_{i}^{p}}{x_{m}^{p}} / \frac{x_{i}^{w}}{x_{m}^{w}}
$$

em que:

$$
\frac{x_{i}^{p}}{x_{m}^{p}} \text { é a parcela das exportações do produto i }\left(X_{i}\right) \text { nas exportações totais }
$$
da agroindústria $\left(\boldsymbol{X}_{\boldsymbol{m}}\right)$ do país considerado $(\mathrm{P})$; e

$$
\frac{x_{i}^{w}}{x_{m}^{w}} \text { é a parcela das exportações mundiais do produto } \mathrm{i}\left(X_{i}^{w}\right) \text { nas }
$$
exportações mundiais de produtos da agroindústria $\left(x_{m}^{w}\right)$.

O pais tem vantagem comparativa com determinado produto, quando $\left(I_{(x)} P_{i}\right)$ for superior à unidade.

Este indicador é calculado para cada produto e subperíodo de forma a se caracterizar, além do padrão atual de vantagem comparativa do pais, a sua evolução ao longo do tempo.

\footnotetext{
${ }^{1}$ Essa formulação é a mesma usada por VEIGA (1991).
} 


\section{2 - ANÁLISE DOS RESULTADOS}

\section{Fontes de crescimento das exportações}

A partir dos resultados do modelo CMS, podem-se analisar a decomposição dos efeitos e a contribuição de cada um no desempenho das exportações agroindustriais brasileiras, nos quatro periodos considerados.

A Tabela 13 apresenta os resultados quando as estimativas levou em consideração cada produto exportado. Inicialmente, observa-se que a taxa de crescimento das exportações brasileiras só foi positiva no primeiro período, ou seja, do início ao final da década de 70 . A partir dai, as taxas foram negativas, refletindo os decréscimos ocorridos no valor das exportações da agroindústria brasileira desde o final dos anos 70 .

Tabela 13 - Taxas de crescimento das exportações agroindustriais brasileiras e mundiais, por produto, e fontes de crescimento das exportações agroindustriais brasileiras, em \%.

\begin{tabular}{llll}
\hline & \multicolumn{3}{c}{ Períodos } \\
\cline { 2 - 4 } & $1973 / 74 / 75$ & $1977 / 78 / 79$ & $1982 / 83 / 84$ \\
& $1977 / 78 / 79$ & $1982 / 83 / 84$ & $1989 / 90 / 91 / 92$ \\
\hline 1.Taxas de crescimento & & & \\
- Exportações brasileiras & 22,75 & $-7,68$ & $-31,28$ \\
- Exportações mundiais & 27,67 & $-28,06$ & 34,92 \\
2. Fontes de crescimento & & & \\
- Crescimento do comércio mundial & 281,76 & $-368,80$ & 73,63 \\
- Composição da pauta de exportações & $-39,77$ & $-51,65$ & $-57,54$ \\
- Destino das exportações & $-68,67$ & $-19,80$ & 6,16 \\
- Competitividade & $-73,31$ & 340,24 & $-122,25$ \\
\hline
\end{tabular}


O comportamento das exportações mundiais segue um ritmo de crescimento semelhante ao observado para o Brasil na década de 70 , mas sofre uma queda bem mais acentuada no inicio dos anos 80 . Desse periodo ao inicio dos anos 90, a retomada do crescimento das exportações mundiais revela-se significativa à taxa de crescimento de $35,0 \%$, enquanto as exportações brasileiras permanecem com tendência decrescente e mais acentuada.

A decomposição do crescimento das exportações constitui fonte de subsidios importantes para a análise dessas tendências ao longo do tempo.

\section{Primeiro Periodo: 1973/74/75 a 1977/78/79}

Neste periodo, caracterizado por maior dinamismo das exportações agroindustriais brasileiras, o efeito crescimento do comércio mundial foi o principal fator explicativo da taxa de crescimento positiva das exportaçọes. $O$ incremento observado ocorreu por força de um fator externo, uma substancial expansão do comércio mundial, resultado de políticas agricolas adotadas, desde meados dos anos 70, pelos principais paises desenvolvidos. MANOEL \& BARROS (1987) mencionam, em estudo sobre as transformações da agricultura brasileira, uma taxa de crescimento anual de $7,1 \%$ atingida pelo comércio internacional na década de 70 , e uma estimativa de apenas $1,8 \%$ para os anos 80 .

O ressurgimento das estratégias protecionistas na década de 70 , entre os paises industrializados (principalmente EUA e paises da UE), o aumento da produtividade e o crescimento populacional inferior à evolução da produção são apontados como alguns fatores que geraram, em nivel mundial, um excesso de estoques de produtos agricolas, que iriam provocar, nos anos 80 , grave crise de excedentes e acirrada disputa por parcelas de mercado. A expansão do produto e os incentivos à exportação, combinados com preços internacionais remuneradores, foram a base do dinamismo do mercado internacional agroexportador na década de 70 .

O desempenho das exportações brasileiras esteve, nesse periodo, extremamente associado a esse dinamismo do comércio internacional, efeito que 
superou a influência dos demais (composição da pauta, destino das exportações e competitividade), cujas contribuições foram negativas, atuando em sentido contrário ao crescimento das exportações?

A competitividade, que estaria refletindo o efeito de um conjunto de fatores, como aumento de produtividade, ajuste da política cambial, incentivos à exportação, entre outros, apresentou o mais forte efeito negativo, significando que, mantida constante a parcela das exportações brasileiras no mercado internacional, a taxa de crescimento teria sido superior na ausência do efeito competitividade. Questões econômicas internas, discutidas a seguir, afetaram 0 setor agroexportador neste periodo e estão associadas a essa influência inversa da competitividade.

A economia brasileira passou, na década de 70 , por um de seus mais importantes ciclos de crescimento. Politicas expansionistas de gastos do govemo, facilidades de crédito ao consumidor, e incentivos fiscais à exportação de produtos manufaturados deram um novo impulso ao setor industrial. Os estimulos ao setor exportador, a política de desvalorização cambial e o comportamento crescente dos preços das principais "commodities" no mercado internacional estimularam o crescimento das exportações totais brasileiras na década de 70 .

Nesse contexto, o setor agricola também passou por um processo de modernização que privilegiou, de certa forma, os produtos destinados à exportação e aqueles utilizados como matéria-prima industrial. A principal força indutora desse crescimento foi o crédito rural, que, além da expansão da oferta, operou com taxas de juros reais negativas.

Nesse periodo, a agricultura abriu-se significativamente ao exterior. A proporção da safra exportada de $10 \%$ no inicio dos anos 60 passou para mais de $20 \%$ na segunda metade dos anos 70 (DIAS, 1983), embora, poucos produtos tenham assumido a liderança nesse processo. A expansão do complexo soja figura como o exemplo mais evidente.

A apropriação dos incentivos e a transformação capitalista da agricultura com elevação da produtividade ocorreram em setores especificos que experimentaram grande impulso na década de 70 . No entanto, a pauta de exportações desta década permaneceu dominada por produtos tradicionais cuja 
capacidade competitiva não foi significativamente afetada e, portanto, insuficiente para provocar um salto qualitativo e atuar como fator explicativo da evolução da taxa de crescimento das exportações agroindustriais brasileiras.

$\mathrm{Na}$ verdade, considerando o grupo dos exportáveis como um todo, durante os anos 70 , a disponibilidade de crédito rural contribuiu mais para a incorporação de novas áreas ao processo produtivo do que para a elevação da produtividade (SAYAD, 1984). Analisando a agricultura de mercado interno e a agricultura de exportação de 1947 a 1985, BENEVENUTO (1989) mostra que, só a partir de 1979, a produtividade passou a dar contribuição maior ao aumento da produção que à expansão da área plantada, tanto para produtos exportáveis quanto para os de mercado interno. O rendimento médio por hectare dos exportáveis cresceu de 1978/80 a 1983/85, à uma taxa anual média de 4,9\%, contra uma evolução da área colhida de $1,9 \%$, enquanto, no periodo anterior a $1978 / 80$, esses percentuais foram de $0,05 \%$ e $3,6 \%$, respectivamente.

Além dessas questões, considera-se ainda, nesse periodo, o crescimento do imposto implícito ao setor primário, representado principalmente por tarifas alfandegárias e restrições quantitativas, que acabou impondo limites à capacidade competitiva da agricultura brasileira de exportação. Os resultados da análise da incidência da taxação implicita sobre a agricultura de exportação, apresentados por OLIVEIRA (1984), acrescentam que, a partir dos anos 70 , os aumentos de preços internacionais não foram repassados à exportação agricola e que uma politica altamente discriminatória de subsidios às exportações tendeu a sobrevalorizar a taxa de câmbio de mercado recebida pelos exportadores agricolas. Este autor conclui, ainda, que a agricultura de exportação tradicional (café, cacau, algodão, fumo) foi a mais penalizada.

Em sintese, apesar de o setor agroexportador ter conseguido avanços importantes relacionados com a capacitação tecnológica, estes foram de caráter localizado, não representando um novo patamar competitivo do setor como um todo. É pela expansão do comércio mundial que se pode explicar o expressivo crescimento das vendas externas dos produtos da agroindústria brasileira na década de 70 , mostrando ser este um condicionante fundamental na evolução do setor agroexportador. 


\section{Segundo Periodo: $1977 / 78 / 79$ a 1982/83/84}

Em relação ao anterior, este período representa um ponto de inflexão no comércio intemacional. A perda de dinâmica das exportações mundiais expressa-se na queda da demanda extema, dados os problemas de endividamento e escassez de divisas, além da auto-suficiência atingida pelos grandes paises importadores, resultante das politicas protecionistas postas em prática nos anos anteriores. A interação desses fatores desencadeou uma tendência de queda nos preços das principais "commodities" agrícolas no mercado internacional. O segundo choque do petróleo (1979) e a elevação das taxas de juros internacionais acentuaram o quadro depressivo do mercado externo do início dos anos 80.

Internamente, diante da nova situação mundial, dos agravantes advindos da paralisação dos fluxos de poupança extema e do aumento do desequilíbrio do balanço de pagamentos, estratégias restritivas foram adotadas pelo Brasil para enfrentar a crise. Como conseqüência, a economia brasileira entra num profundo processo recessivo e o ajustamento extemo acaba criando as condições para o direcionamento da produção para o mercado intemo.

Os resultados da decomposição das fontes de crescimento das exportações brasileiras expressam essa mudança de tendência na medida em que se inverte o padrão de contribuição dos efeitos no desempenho das exportações neste periodo. $O$ desaquecimento do comércio mundial refletindo a retração da demanda externa passa a ser o fator mais fortemente desfavorável ao crescimento das exportações, revelando o processo recessivo da economia mundial.

A competitividade, ao contrário, é o fator de maior contribuição para explicar o crescimento das exportações deste período, superada, no entanto, pelos efeitos negativos combinados do comércio mundial principalmente, da composição da pauta e do destino das exportações.

Algumas altemativas podem ser levantadas como fatores explicativos para o forte efeito competitividade desse periodo.

Ao final da década de 70 e início de 80 , a política comercial brasileira passou por grandes mudanças. Observa-se uma expressiva redução dos 
subsidios à exportação (direcionados ao setor exportador de manufaturas) por força dos ajustes fiscais e monetários requeridos para reequilibrar as contas externas e atender a pressões dos organismos internacionais GATT (General Agreement on Tariffs and Trade) e FMI (Fundo Monetário Internacional).

Por outro lado, após um periodo de prefixação cambial com desvalorizações baseadas na previsão da inflação interna, uma política cambial mais agressiva, adotada como compensação, incluiu duas maxidesvalorizações de $30 \%$ da moeda brasileira em relação ao dólar, em dezembro de 1979 e em fevereiro de 1983. Essa medida não causou, no entanto, grande impacto ao setor agroexportador, tanto pelo seu efeito rápido em razão do acelerado processo inflacionário, quanto pela deterioração do quadro externo do momento.

Devem ser mencionadas, ainda, neste periodo, as restrições às exportações representadas pelos impostos aplicados sobre os bens agricolas com o propósito de evitar escassez e desabastecimento interno.

Ademais, é necessário considerar a queda dos preços das principais "commodities" brasileiras, principalmente dos produtos da agroindústria, nos três primeiros anos da década de 80 , como reflexo dos juros altos e da retração da economia mundial. Essa queda, que ocorreu em setores constituidos de produtos relativamente homogêneos, não se traduziu em ganhos de competitividade, mas em perda de rentabilidade (PINHEIRO \& HORTA, 1993).

O fato marcante na evolução da competitividade foi o salto tecnológico de exportáveis agroindustriais especificos, como os setores de pasta química de madeira, papel, soja e suco de laranja. O Pais conseguiu ampliar espaços no mercado internacional para estes produtos, como se poderá confirmar pelos resultados dos indicadores de vantagem comparativa analisados na próxima seção.

Essa expansão da capacidade produtiva tem sua origem em decisões passadas, mais especificamente nos investimentos realizados pelo II PND (1974/78), que privilegiavam a implantação de indústrias de bens de capital e produtos intermediários, substitutivos de importações.

Segundo CASTRO \& SOUZA (1985), os grandes programas setoriais desenvolvidos na estratégia de 1974 tiveram a função de aliviar o 
estrangulamento externo no momento do colapso da capacidade de importar, ocorrido de 1979 a 1982, esta considerada uma crise mais aguda que a de 1973/74, que teria inspirado as propostas do II PND.

Fatalmente, o primeiro choque do petróleo, ocorrido em 1973, atingiu a economia brasileira em pleno periodo do "milagre econômico" (1968/73) quando a taxa de crescimento do PIB alcançou o recorde de $10 \%$ a. a. Nesse momento, a política econômica interna, ao contrário da adotada por outros países não-produtores de petróleo, optou pela continuidade do crescimento econômico, no caso pela implementação dos projetos constantes do II PND, por meio do endividamento externo que financiaria também as importações de petróleo.

A estratégia adotada foi a de uma economia em desenvolvimento, que decidiu não provocar uma recessão como meio de lidar com a adversidade externa (BACHA, 1984), ou seja, a decisão foi a de isolar o País da crise energética mundial, mantendo a proposta de constituição de uma moderna economia industrial. Como consequência, o endividamento externo aumentou mais de $150 \%$ no período de $1974 / 78$ (PFEIFER, 1990).

Políticas restritivas só iriam ser adotadas a partir do final de 1979 e início de 80 , com a segunda crise do petróleo, e incluíram, além de outras medidas, corte de investimentos e elevação da taxa de juros interna.

Fenômenos ocorridos na economia brasileira em 1983/84 como eliminação do déficit em transações correntes, reconstituição das reservas externas e arrefecimento do galopante crescimento da divida, foram para CASTRO \& SOUZA (1984) resultados da maturação dos investimentos do II PND, que possibilitaram a constituição de um parque industrial competitivo, visando a conquista de novos espaços no mercado extemo. $O$ valor das exportações passou então a representar quase o dobro do valor das importações. No caso da agroindústria, os complexos soja (farelo), citrus (suco de laranja), e madeira (pasta quimica e papel). É importante observar que esses produtos, que permitiram a geração de excedentes exportáveis são de origem manufaturada, ou seja, incorporam algum grau de industrialização. Por certo, este fato está associado ao processo de mudança que vem ocorrendo na estrutura da pauta de exportações da agroindústria brasileira. 
Os relatórios do Estudo da Competitividade da Indústria Brasileira' comprovam as intensas transformações ocorridas no setor produtivo agroindustrial. $O$ apoio institucional do Estado à indústria de papel e celulose, nos anos 70 (JORGE, 1993), oferecendo diferentes tipos de subsídios (incentivos fiscais, importação de equipamentos, empréstimos a juros subsidiados e apoio à pesquisa científica e tecnológica), constituiu forte estímulo à execução de projetos de expansão e melhoria de eficiência das unidades produtivas, com forte orientação exportadora.

Esse relatório apresenta também uma análise do desempenho da indústria de suco de laranja concentrado no Brasil (LIFSCHITZ, J. A., 1993) e mostra sua estreita associação com a dinâmica exportadora com crescimento exponencial, após a primeira crise do petróleo. A intervenção do Estado, nesse período, por meio de políticas de preço e estocagem, consolidação de uma rede pública de pesquisas voltadas para o setor, e incentivos financeiros à produção $e$ industrialização, foi fator determinante para a elevação da competitividade da indústria brasileira de suco de laranja concentrado.

Quanto ao complexo soja, a política dos anos 70 foi de estimular a expansão da indústria doméstica de esmagamento e promover a exportação dos derivados em detrimento do grão, que seria retido como matéria-prima para a indústria (SANTANA, 1984).

De maneira geral, a proteção industrial aumentou a industrialização de bens agrícolas. Reduziram-se as exportações de matérias-primas, cedendo espaço para os agroprocessados como café industrializado, farelo e óleo de soja, manteiga de cacau e pó-de-cacau, entre outros (CARVALHO, 1989).

Essas evidências ajudam a explicar a alta participação do efeito competitividade como fonte de crescimento das exportações brasileiras neste período recessivo. Apesar do decréscimo do valor exportado pela agroindústria brasileira $(-7,7 \%)$, a queda foi bem inferior à registrada em nivel mundial $(-28,0 \%)$ e teria sido mais acentuada na ausência do efeito competitividade. Isso porque, como pode-se observar, o efeito crescimento do comércio mundial foi

\footnotetext{
${ }^{1}$ Documentos elaborados por IE/UNICAMP - IEI/UFR - FDC - FUNCEX.
} 
extremamente negativo, assim como os efeitos composição da pauta e destino das exportações, estes dois últimos, de menor magnitude.

Com relação ao destino das exportações, embora com sinal inverso, dá-se com peso menor do que no periodo anterior, indicando um certo sentido de direcionamento das exportações agroindustriais para mercados mais dinâmicos.

Terceiro Periodo: 1982/83/84 a 1989/90/91/92

Nesse último periodo, a principal fonte de crescimento das exportações agroindustriais brasileiras volta a ser o crescimento do comércio mundial, o que reflete a reversão da situação depressiva mundial e a recuperação do comércio intemacional, que se manifesta desde 1984 e está expressa na evolução da taxa de crescimento das exportações que passa de $-28,0 \% \mathrm{em}$ 1982/83/84 para 34,9\% em 1989/90/91/92.

Esse expressivo crescimento está efetivamente relacionado às políticas adotadas nos anos 80 pelos principais paises desenvolvidos. A grande formação de estoques agricolas, principalmente pelos EUA e UE, foi uma decorrência das políticas de proteção ao setor e das rápidas mudanças tecnológicas que provocaram aumento de produtividade e conseqüentemente de excedentes de produção. Segundo a OCDE (1987, 1988), citada por JANK (1990), entre os periodos de 1979/81 e 1984/86, o custo das políticas agricolas aumentou em média $119 \%$ no Canadá, $174 \%$ nos EUA e $40 \%$ na UE. Na década de 80 , vários programas de incentivos diretos às exportações foram criados por estes paises para escoar os excedentes de produção no mercado extemo. As despesas gorvemamentais da UE e dos EUA para garantirem os mercados agricolas estão em tomo de 50 bilhões de dólares por ano.

Goldin \& Knudsen, citados por HOMEM DE MELO (1993), apresentaram evidências empíricas indicando que 0 conjunto das políticas intervencionistas da UE, EUA e Japão provocaram um rebaixamento artificial nos preços dos produtos agricolas no mercado intemacional. 
Vários estudos desenvolvidos no início da década de 90 estimaram os efeitos da liberalização comercial nos paises desenvolvidos. BRANDÃO \& MARTIM (1993) fizeram uma análise comparativa dos resultados desses estudos e concluiram que, mesmo havendo variações consideráveis entre eles, observam-se alguns padrões consistentes. Eliminada a proteção à agricultura, a oferta dos países desenvolvidos cai e a previsão é de aumento dos preços mundiais de várias "commodities", em diferentes graus.

Em sintese, há evidências claras mostrando a relação entre a intervenção governamental nos fluxos de comércio dos países desenvolvidos e as altas taxas de crescimento das exportações mundiais nesse periodo.

Outra questão a ser considerada, na análise dos resultados, é que a economia mundial, apesar de ter-se expandido sensivelmente no período que se seguiu à recessão, chegando a crescer mais de $4 \%$ em 1988, passa por outro surto recessivo a partir de 1989 , de natureza diferente, mas que implica, da mesma forma numa queda de demanda pelos produtos de exportação (NONNEMBERG et alii, 1994). Políticas monetárias mais rígidas foram adotadas nas principais economias do mundo dada a retomada da inflação, o que trouxe como conseqüência uma desaceleração da atividade econômica. A taxa de crescimento do produto real dos paises da OCDE caiu de 4,2\% em 1988 para 2,3\% em 1990 (BRANCO et alii, 1992).

Assim, o efeito do comércio mundial sobre as exportações brasileiras, apesar de significativo, é de magnitude inferior à observada no primeiro período analisado, em função desses reveses ocorridos em determindos anos do periodo.

A economia brasileira, na primeira metade dos anos 80 , sofreu os impactos do setor extemo e os decorrentes da recessão interna. Na segunda metade, observou-se um expressivo aumento dos gastos públicos e da inflação e uma redução da capacidade arrecadadora do Estado. Os vários planos econômicos, em prática desde 1986, não conseguiram atingir a meta de estabilização de preços. O programa básico de reformas estruturais de 1990 que consistia de liberalização gradual do comércio exterior, retomada das relaçōes com a comunidade financeira internacional, privatização de empresas públicas, desregulamentação da economia, liberalização dos preços e programas de 
qualidade e produtividade (OLIVEIRA \& SILVA, et alii), obteve êxitos parciais, porém insuficientes para se alcançar a almejada estabilidade econômica.

Enfim, a crise macroeconômica brasileira, que perdurou (com raras exceções) durante toda a década de 80 e início dos anos 90 , criou restrições ao aproveitamento das oportunidades abertas no mercado internacional no momento em que a economia mundial voltava a crescer e oferecia perspectivas de crescimento ao setor exportador brasileiro. Embora os efeitos crescimento do comércio mundial e destino das exportações tenham sido positivos (o último relativamente menor), a taxa de crescimento das exportações brasileiras, ao contrário da mundial, permaneceu negativa e de valor absoluto maior que o do periodo anterior $(-31,3 \%)$.

O principal fator desacelerador do desempenho das exportações foi a competitividade, ou seja, mantida a participação no mercado internacional, a taxa de crescimento das exportações brasileiras teria sido crescente ou decrescente em menor proporção, se tivessem existido condiçōes de competitividade.

Por ser um indicador que reflete a interação de diferentes fatores, alguns aspectos são analisados e associados ao seu compoortamentos neste período.

Observou-se, na economia brasileira, após a interrupção do fluxo de poupança externa no início dos anos 80 , uma inversão em termos de transferências líquidas ao exterior, e o País passou à condição de exportador líquido de capitais. Como conseqüência, houve queda de investimentos que, combinada com a plena utilização da capacidade instalada atingida em 1986 (PFIFER 1990), impôs uma restrição ao crescimento da produtividade e por conseqüência da competitividade dos produtos brasileiros no mercado internacional. Ganhos de produtividade foram registrados, mas em setores especificos, ou seja, não se caracterizaram como um fenômeno geral. Acrescentase, ainda, o fato de que entre os principais paises exportadores ocorreram significativos ganhos de produtividade em função do modelo de forte uso de capital intensivo que fundamentou os programas de incentivo à produção. 
A discussão da competitividade do setor agroindustrial remete, novamente, à questão da taxação implícita já abordada na análise do primeiro periodo. Evidências empiricas mais recentes (PINHEIRO \& ALMEIDA, 1993) reafirmam a histórica proteção do setor industrial, acrescentando que, em nenhuma das reformas tarifárias implementadas (1967, 1988 e 1990/93), houve significativa ruptura deste padrão. Segundo esses autores "os setores mais modemos, ou de maior intensidade tecnológica, conquistaram, progressivamente, espaço entre os mais protegidos, particularmente, a partir de 1988 e $1990^{n}$.

A discriminação tarifária entre as atividades agricola e industrial é também destacada nos resultados do trabalho de KUME (1993). Argumenta-se que as tarifas aduaneiras incidentes sobre os produtos agricolas são insuficientes para compensar os subsidios à agricultura fornecidos pelos EUA e pela UE, ou seja, o setor agricola recebe um nivel de proteção inadequado frente aos produtos externos apoiados pelos governos locais.

As barreiras não tarifáricas (qualidade, sanidade, entre outras) dos produtos exportados pela agroindústria vão se tomando também cada dia mais rigorosas influenciando a competitividade externa do setor.

O contexto de preços internos mais atraentes que o vigente no mercado internacional foi outro fenômeno relacionado ao comportamento do setor agrícola nos anos 80 , de retomada de crescimento da produção de bens de consumo doméstico. A relativa recuperação dos salários e contração dos preços públicos no periodo de 1985 a 1988 tiveram também influência na demanda por estes bens. Somando-se ainda a elevação dos termos de troca na agricultura, a conseqüência foi o redirecionamento da produção para o mercado interno em detrimento das exportações.

A menor competitividade dos produtos brasileiros no mercado internacional é ainda um reflexo do comportamento da taxa de câmbio real, de meados da década de 80 a início da de 90 , como já mostrado no capitulo introdutório. Em linhas gerais, este se caracterizou pela instabilidade, com tendência clara de defasagem cambial, ocorrendo periodos de acentuada sobrevalorização, que afetou sensivelmente a competitividade das exportações brasileiras. HOMEM DE MELO (1993), comparando as taxas médias de câmbio real de 1985 com as de março de 1990 concluiu que a moeda brasileira teve uma 
valorização de $56,3 \%$ frente ao dólar norte-americano e de $45,1 \%$ frente a cesta de moedas dos principais parceiros comerciais do Brasil.

$\mathrm{Na}$ verdade, o valor real das exportações totais brasileiras apresentou, neste último periodo, comportamento estável, com ligeira tendência de crescimento (Apêndice 7). O valor real exportado pela agroindústria, entretanto, foi sempre decrescente como mostram os dados analisados no Capitulo 2. Esses resultados dão indicações de que o setor industrial teve condições de suportar melhor a sobrevalorização que o agroindustrial. Caracteristicas especificas de diferenciação de produtos, segmentação de mercados, entre outras, conferem ao setor industrial uma maior margem de competitividade e uma maior capacidade de absorver e intemalizar as variações de preços resultantes da defasagem cambial.

De importância nos resultados desse último periodo, destaca-se o fato de ter sido a competitividade, um fator relacionando às políticas internas, 0 principal responsável pela queda das exportações. Isto abre possibilidades de atuação na conquista de maiores parcelas de mercado num contexto de crescimento do comércio mundial, recuperando a importância do setor agroexportador como elemento-chave para políticas de desenvolvimento e equilibrio das contas externas.

O efeito composição da pauta apresentou, nos três periodos analisados, resultados semelhantes em magnitude e sempre negativos, ou seja, contribuiu para desacelerar o crescimento das exportações brasileiras, revelando que a pauta de exportações permaneceu concentrada em produtos de crescimento mais lento, em relação ao mercado mundial. Embora venham ocorrendo mudanças na estrutura da pauta, com tendência clara de maior participação de produtos com mais alto grau de transformação industrial, estas não se consolidaram definitivamente e, em termos de peso relativo, revelaram-se insuficientes para explicar o diferencial de variação na taxa de crescimento das exportações, nos periodos analisados, mantendo, no agregado, uma contribuição negativa e estável quando se procede à decomposição dos efeitos.

Os resultados referentes às fontes de crescimento das exportações, quando os produtos são agregados em básicos, semimanufaturados e manufaturados (Tabela 14), não apresentam variações quanto ao padrão dos resultados obtidos na estimativa por produto. As diferenças ocorrem quanto à 
magnitude de alguns coeficientes, sendo as mais acentuadas correspondentes aos efeitos crescimento do comércio mundial e competitividade. Por exemplo, no primeiro periodo, o efeito crescimento do comércio mundial permanece positivo e forte, porém mais reduzido quando a análise é feita por agregado e o efeito competitividade permanece negativo, mas, também, menos acentuado, ou seja, tem uma contribuição relativamente menor para reduzir as exportações.

Tabela 14 - Taxas de crescimento das exportações agroindustriais brasileiras e mundiais, por agregado, e fontes de crescimento das exportações agroindustriais brasileiras, em \%

\begin{tabular}{lccc}
\hline & \multicolumn{3}{c}{ Períodos } \\
\cline { 2 - 4 } & $1973 / 74 / 75$ & $1977 / 78 / 79$ & $1982 / 83 / 84$ \\
& $1977 / 78 / 79$ & $1982 / 83 / 84$ & $1989 / 90 / 91 / 92$ \\
\hline 1.Taxas de crescimento & & & \\
- Exportações brasileiras & 22,75 & $-7,68$ & $-31,28$ \\
- Exportações mundiais & 27,67 & $-28,06$ & 34,92 \\
2. Fontes de crescimento & & & \\
- Crescimento do comércio mundial & 120,12 & $-352,12$ & 115,60 \\
- Composição da pauta de exportações & 32,24 & $-32,98$ & $-19,20$ \\
- Destino das exportações & $-33,69$ & $-27,10$ & 7,00 \\
- Competitividade & $-18,67$ & 312,19 & $-203,40$ \\
\hline
\end{tabular}

No segundo periodo, os resultados relativos aos três agregados não apresentaram diferenças significativas em relação aos estimados por produto.

$E$, no último periodo, ocorre o inverso observado para o primeiro. $O$ efeito crescimento do comércio mundial permanece positivo, mas magnificado, ou seja, tem uma contribuição maior no sentido de aumentar a taxa de crescimento das exportações. $O$ efeito competitividade é também superior em termos absolutos e permanece negativo, contribuindo mais fortemente para o sentido inverso, ou seja, para o decréscimo das exportações. 
Quanto ao efeito comércio mundial, as diferenças ocorrem em razão de variabilidade nas estimativas do coeficiente “ $r$ ", que representa a variação média das exportações mundiais dentro de cada período. No primeiro, o valor desse coeficiente por produto apresentou maior amplitude de variação e a média resultante foi superior à estimada para os agregados cujos indices individuais foram menores, mais estáveis e resultaram em média inferior. Assim, o efeito comércio mundial é um pouco mais acentuado quando se considera cada produto exportado. No terceiro periodo, ocorre o inverso e o peso deste efeito é atenuado nas estimativas por produto.

O efeito competitividade apresentou peso relativo menor no sentido inverso ao crescimento das exportações quando as estimativas foram feitas por agregado no primeiro período e, mais acentuado, no terceiro. Essas diferenças são devidas às variações de ganhos e perdas de competitividade, que vão ocorrendo ao longo do tempo e que não são homogêneas nem generalizadas. Quando se considera uma pauta de produtos muito diversificada em um periodo de tempo mais longo, como neste estudo, há maior probabilidade de ocorrerem diferenças entre as estimativas quando estas se referem a cada produto, mas podem ser atenuadas ou acentuadas na medida em que se procede à agregação.

$\mathrm{Na}$ verdade, o mais relevante e fundamental nesta análise é a permanência do mesmo padrão dos resultados na explicação do comportamento das exportações brasileiras nos dois procedimentos alternativos.

Em sintese, da análise dos resultados das fontes de crescimento das exportações brasileiras da agroindústria fica clara a importância relativa de dois fenômenos: um de natureza exógena, que é o comportamento da demanda externa (efeito crescimento do comércio mundial), e outro, que representa a interação de um conjunto de fatores internos, que é a competitividade relativa. Neste aspécto o pais tem conseguido avanços significativos em determinados setores, que têm-se tornado mais competitivos internacionalmente.

Os resultados dos indicadores de Vantagem Comparativa Revelada, discutidos a seguir, mostram esse fenômeno: a evolução do desempenho das exportações brasileiras por produto da agroindústria, em relação à evolução ocorrida em nivel mundial. 


\section{Indicadores de Vantagem Comparativa Revelada}

Os resultados, apresentados na Tabela 15, quantificam o peso relativo das exportações de cada produto na pauta de exportações da agroindústria brasileira, em relação à situação ocorrida em nivel mundial. Pode-se observar também o quadro evolutivo da vantagem comparativa desses produtos ao longo do periodo analisado.

Dos 20 produtos incluídos, os índices referentes ao último período (1989/90/91/92) são superiores à unidade - o que indica vantagem comparativa internacional - em nove casos: suco de laranja, farelo de soja, óleo de soja, cacau em pasta, café em grão, café solúvel, soja em grão, fumo e manteiga de cacau. Os maiores valores referem-se ao suco de laranja $(11,5)$ e ao farelo de soja $(6,5)$. Os produtos cacau bruto e açúcar bruto apresentam indicadores de vantagem comparativa iguais à unidade. Esses resultados revelam que, apesar da tendência de diversificação da composição da pauta de exportações da agroindústria brasileira, o País permanece com um padrão de especialização com certa dominância de produtos tradicionalmente exportados.

A análise evolutiva, no entanto, confirma aspectos importantes: os complexos cacau e café (produtos e subprodutos), exportáveis tradicionais, apesar de não apresentarem indices inferiores à unidade, sofreram redução ou mantiveram estabilidade nos últimos períodos considerados. Isso confirma a perda de vantagem comparativa no mercado internacional, fato já verificado nos resultados do Capitulo 2.

Farelo de soja e soja em grão apresentaram tendência irregular no comportamento dos indicadores de vantagem comparativa, mas na última década, estes foram crescentes.

Merece atenção a evolução positiva dos indices estimados para suco de laranja nos quatro períodos, reafirmando a significativa expansão de suas exportações, de forma mais acentuada a partir de final da década de 70 . Considerando cada produto individualmente, o suco de laranja oscila atualmente entre o segundo e terceiro lugares na pauta de exportações da agroindústria brasileira. 
Tabela 16 - Indicadores de Vantagem Comparativa Revelada por produto da agroindústria brasileira.

\begin{tabular}{|c|c|c|c|c|}
\hline \multirow[t]{2}{*}{ PRODUTO } & \multicolumn{4}{|c|}{ Períodos } \\
\hline & $1 9 7 3 \longdiv { 7 4 / 7 6 }$ & $1977 / 78 / 79$ & $1982 / 83 / 84$ & $1990 / 91 / 92$ \\
\hline $\begin{array}{l}\text { Suco de laranja } \\
\text { Farelo de soja } \\
\text { Oleo de soja } \\
\text { Cacau em pasta } \\
\text { Café em grao } \\
\text { Café solúvel } \\
\text { Soja em grao } \\
\text { Fumo } \\
\text { Cacau (manteiga) }\end{array}$ & $\begin{array}{l}2.182 \\
3.796 \\
0.742 \\
2.663 \\
4.381 \\
4.860 \\
2.644 \\
0.623 \\
2.433\end{array}$ & $\begin{array}{l}7.233 \\
6.031 \\
3.172 \\
6.190 \\
2.878 \\
6.476 \\
0.838 \\
1.130 \\
1.829\end{array}$ & $\begin{array}{l}9.132 \\
4.899 \\
3.111 \\
7.730 \\
3.106 \\
4.640 \\
0.633 \\
1.496 \\
1.934\end{array}$ & $\begin{array}{r}11.464 \\
6.632 \\
3.718 \\
3.714 \\
3.256 \\
3.037 \\
2.974 \\
2.284 \\
2.282\end{array}$ \\
\hline $\begin{array}{l}\text { Cacau (bruto) } \\
\text { Acúcar (bruto) }\end{array}$ & $\begin{array}{l}1.627 \\
2.266\end{array}$ & $\begin{array}{l}2.083 \\
0.678\end{array}$ & $\begin{array}{l}1.177 \\
0.472\end{array}$ & $\begin{array}{l}1.029 \\
1.002\end{array}$ \\
\hline $\begin{array}{l}\text { Pasta química de madeira } \\
\text { Peles e couros } \\
\text { Açúcar refinado } \\
\text { Carne bovina industrializada }\end{array}$ & $\begin{array}{l}0.007 \\
0.105 \\
0.292 \\
0.394\end{array}$ & $\begin{array}{l}0.174 \\
0.113 \\
0.880 \\
0.135\end{array}$ & $\begin{array}{l}0.616 \\
0.297 \\
0.893 \\
1.023\end{array}$ & $\begin{array}{l}0.792 \\
0.776 \\
0.776 \\
0.769\end{array}$ \\
\hline $\begin{array}{l}\text { Algodao bruto } \\
\text { Tecidos } \\
\text { Carne bovina fresca cong./resfriada } \\
\text { Papel } \\
\text { Algodao em fios }\end{array}$ & $\begin{array}{l}0.748 \\
0.176 \\
0.214 \\
0.012 \\
0.080\end{array}$ & $\begin{array}{l}0.108 \\
0.198 \\
0.031 \\
0.044 \\
0.151\end{array}$ & $\begin{array}{l}0.263 \\
0.273 \\
0.170 \\
0.121 \\
0.162\end{array}$ & $\begin{array}{l}0.346 \\
0.327 \\
0.169 \\
0.169 \\
0.126\end{array}$ \\
\hline
\end{tabular}


Resultado semelhante observa-se para o fumo, cujos indicadores são sempre crescentes, embora em menor magnitude.

Entre os produtos da agroindústria brasileira, cujos indicadores de vantagem comparativa são inferiores à unidade, é importante destacar alguns aspectos. Para um grupo deles, além dos indicadores estimados terem atingido, no último periodo, valores próximos de um, o que pode ser considerada uma situação de "quase especialização", apresentaram, ao longo do periodo, uma excepcional evolução crescente. É o caso de pasta química de madeira, peles e couros, açúcar refinado e came bovina industrializada. Também com comportamento ascendente em todo o periodo analisado, mas com valores bem inferiores à unidade, observam-se os indices referentes a papel e tecidos.

Tais resultados, além de indicarem espaços potenciais de crescimento das exportações brasileiras, confirmam a tendência de mudanças na estrutura da pauta, para maior sofisticação tecnológica, e a participação crescente de produtos com mais elevado grau de transformação industrial.

Esse fenômeno fica também evidenciado, com clareza, na análise da evolução dos indicadores de vantagem comparativa quando os produtos são classificados em básicos, semimanufaturados e manufaturados (Tabela 16). Observa-se a tendência de redução dos indices referentes aos produtos básicos nos vários períodos, que, no entanto, permanecem superiores à unidade, ou seja, com peso na pauta de exportações brasileiras superior ao obsenado na pauta mundial, reforçando a permanência do padrão de especialização da agroindústria brasileira.

Trajetória inversa ocorre com os semimanufaturados e manufaturados cujos valores são crescentes ao longo do tempo. Alteração mais significativa é observada para os semimanufaturados cujos indicadores passaram a valores superiores à unidade desde o final da década de 70 , indicando ganho de vantagem comparativa. No caso dos manufaturados, a tendência é crescente, porém menos acentuada, e o valor do coeficiente permanece inferior à unidade, o que indica o sentido da evolução, mas não chega a caracterizar uma situação de vantagem comparativa intemacional. 
Os produtos que tiveram maior influência no crescimento dos indicadores relativos aos produtos semimanufaturados foram, sem dúvida, a pasta química de madeira e os subprodutos peles e couros cujos coeficientes apresentaram maior crescimento, como mencionado anteriormente.

Tabela 16 - Indicadores de vantagem comparativa revelada, por agregado da agroindústria brasileira

\begin{tabular}{lllll}
\hline \multicolumn{1}{c}{ Agregados } & \multicolumn{4}{c}{ Períodos } \\
\cline { 2 - 5 } & $1973 / 74 / 75$ & $1977 / 78 / 79$ & $1982 / 83 / 84$ & $1989 / 90 / 91 / 92$ \\
\hline Básicos & 1,831 & 1,181 & 1,034 & 1,161 \\
Semimanufaturados & 0,663 & 1,516 & 1,626 & 1,760 \\
Manufaturados & 0,233 & 0,464 & 0,626 & 0,552 \\
\hline
\end{tabular}

Dos produtos classificados como manufaturados, o suco de laranja apresentou aumento expressivo nos indicadores de vantagem comparativa ao longo do tempo, o mesmo acontecendo com tecidos e papel, em proporções inferiores. Mas, ao mesmo tempo, outros produtos deste grupo apresentaram redução dos coeficientes ou estes permaneceram estáveis, o que teve influência no sentido de atenuar a intensidade de crescimento do indicador de vantagem comparativa dos manufaturados.

Esses resultados, da mesma forma que os obtidos por produto, são reveladores da mudança por que vem passando a estrutura da pauta agroexportadora brasileira na direção de um maior crescimento da participação de produtos industrializados (semimanufaturados e manufaturados). Essas mudanças, embora sinalizem uma nova natureza de inserção comercial do Brasil na economia mundial, caracterizam um processo que está em curso e não um padrão consolidado de desenvolvimento da agroindústria brasileira. 


\section{CONCLUSÕES}

A economia brasileira passou, nos anos 70 , por um intenso processo de industrialização, parte da estratégia de complementaçâo đo modelo de substituição de importações.

A política de endividamento externo foi adotada para manter o nivel da atividade econômica e isolar a economia dos efeitos negativos da crise internacional, provocada por dois choques energéticos consecutivos e seus desdobramentos.

O forte impacto sobre o balanço de pagamentos brasileiro da elevação das taxas de juros internacionais agravado pela intemupção dos fluxos de poupança externa criou as condições para imposição de políticas econômicas restritivas no início da década de 80 , direcionadas ao ajuste do desequilíbrio das contas externas.

Apesar de a política de ajustamento externo ter priorizado a contenção das importações e o estímulo às exportações, o setor exportador agrícola começou a perder dinamismo, reflexo da queda da demanda externa, dadas a situação depressiva da economia mundial e a evolução desfavorável dos preços das principais "commodities" no mercado internacional, além da autosuficiência adquirida pelos paises importadores de produtos da agroindústria brasileira.

Dentre as políticas setoriais internas, a reforma do sistema de financiamentos rurais, combinada com a conjuntura recessiva da economia, contrariou as expectativas de crise na agricultura brasileira. Durante a década de 80, a melhoria dos termos de troca domésticos, a politica cambial que, apesar das desvalorizações, manteve tendência de defasagem, e o contexto de preços 
internacionais desfavoráveis levaram ao direcionamento da produção agricola para o mercado interno. Em estudo detalhado sobre política agricola e agricultura na década de 80, REZENDE (1988) concluiu que o processo de ajustamento externo criou as condições favoráveis à agricultura de mercado interno, a qual passou de retardatária, na década de 70 , a motor do crescimento agrícola na de 80 .

-Nesse contexto, o setor agricola exportador teve participação limitada no esforço de geração de divisas. O menor dinamismo das exportações agricolas brasileiras foi acompanhado de mudança na composição da pauta, em termos de uma tendência crescente de participação de produtos com maior grau de transformação indústrial, ou seja, de relativa "modernização" de sua estrutura.

Nesse sentido, os dados empíricos mostraram o crescimento acelerado do valor das exportações da agroindústria na década de 70 , a expressiva queda ocorrida no inicio da década de 80 , e uma fase de relativa estabilidade que se seguiu, com novos decréscimos registrados no início da década de 90.

Entre os agregados básicos, semimanufaturados e manufaturados, - comportamento das exportações, embora semelhante ao ocorrido no total, apresentou, ao final da década de 80 e nos primeiros anos de 90 , uma dinâmica claramente diferenciada: o valor exportado dos produtos básicos decresceu acentuadamente; com os semimanufaturados e manufaturados ocorreu o inverso, ou seja, uma tendência favorável na evolução das exportações.

O indice de preços dos exportáveis mostrou-se um importante fator explicativo desse comportamento.

A hipótese de ocorrência de alterações na estrutura da pauta evidenciou-se também nos resultados de participação de cada agregado no valor total exportado. Ao longo do periodo analisado, a trajetória foi de decréscimo do peso dos básicos e de aumento gradativo da participação dos semimanufaturados e manufaturados.

No comércio internacional, a análise da evolução da estrutura do setor exportador agroindustrial revelou não ser este um fenômeno especifico do Brasil, uma vez que vem ocorrendo em outros paises, especialmente da América 
Latina. $\dot{E}$, no entanto, um processo muito mais intenso e persistente no mercado agroexportador brasileiro.

Vistos de uma perpectiva desagregada, os resultados mostraram a expressiva perda de peso dos exportáveis tradicionais - café em grãos, açúcar bruto, algodão bruto e cacau cru - enquanto farelo de soja, pasta química de madeira, papel e suco de laranja começaram a sobressair como pólos mais dinâmicos, liderando esse processo de transformação.

A evolução dos indicadores de Vantagem Comparativa Revelada (VCR) são confirmadores desse quadro geral. Os complexos cacau e café (produtos e subprodutos) - exportáveis tradicionais - perderam vantagem comparativa no mercado internacional, embora tenham permanecido com indices superiores à unidade. Os maiores valores referiram-se a suco de laranja e farelo de soja. Pasta quimica de madeira, peles e couros, carne bovina industrializada, papel e tecidos apresentaram, ao longo do periodo, indices evolutivos também crescentes.

Entre os agregados, a evolução do indicador de VCR dos produtos básicos foi decrescente, mas o valor permaneceu superior à unidade. Ao contrário, os indices referentes aos semimanufaturados e manufaturados tiveram comportamento crescente, os primeiros atingindo valores superiores à unidade desde o final da década de 70 .

Apesar dessas evidências caracterizarem uma nova natureza de inserção comercial do setor agroexportador no mercado mundial, não permitem conclusão definitiva sobre a consolidação de um novo padrão de especialização, senão a caracterização de um fenômeno que está em curso, dada a permanência, com relativa importância na pauta, de produtos básicos tradicionalmente exportados. São, no entanto, resultados que sinalizam a linha de tendência do fluxo do comércio agroexportador brasileiro e que revelam os espaços potenciais para o crescimento do capital agroindustrial no mercado externo.

A análise das fontes de crescimento das exportações mostrou a importância do crescimento do comércio mundial e da competitividade no desempenho das exportações agroindustriais brasileiras. A contribuição dessas variáveis ocorreu, no entanto, em todos os periodos analisados, em sentidos 
opostos, ou seja, quando o principal fator explicativo do crescimento das exportações foi o melhor desempenho do mercado mundial, 0 efeito da competitividade atuou em sentido inverso, e vice-versa.

No primeiro periodo (1973/74/75 a 1977/78/79), quando o comércio mundial passava por uma fase de dinamismo, à qual esteve associado o também favorável desempenho exportador brasileiro, a competitividade apresentou o mais forte efeito negativo, ou seja, não atuou no sentido de ampliar os espaços no mercado internacional.

No periodo seguinte (de 1977/78/79 a 1982/83/84), quando ocorreu a expansão da capacidade produtiva nacional, fruto principalmente da maturação dos investimentos realizados pelo II PND, prevaleceu o efeito competitividade como fator explicativo do desempenho das exportações. Nesse periodo, no entanto, a situação da economia mundial era depressiva e exerceu impacto altamente negativo sobre as exportações brasileiras, atuando para neutralizar 0 efeito positivo da competitividade, que, no entanto, impediu que a queda das exportações brasileiras fosse mais acentuada que no comércio internacional.

No período em que o comércio mundial recuperou seu ritmo de crescimento (de 1882/83/84 a 1989/90/91/92) e passou a ser o principal fator explicativo do comportamento das exportações agroindustriais brasileiras, a competitividade voltou a exercer forte efeito negativo sobre o setor. Diversos fatores, como queda de investimentos, preços internos mais atrativos e comportamento instável do câmbio, impuseram restrições à conquista de maiores parcelas de mercado. A estabilização econômica que os vários planos de governo não conseguiram atingir acabou criando as restrições a um maior dinamismo do setor exportador brasileiro no momento em que o cenário externo era altamente favorável à expansão da capacidade brasileira de exportar.

Das evidências empiricas obtidas, algumas questões merecem ser destacadas como fundamentais no processo de ampliação das possibilidades de crescimento do setor agroexportador brasileiro.

A dinâmica do comércio mundial é um determinante essencial do desempenho do comércio externo do País. A economia brasileira, no entanto, não tem conseguido aproveitar as fases de dinamismo das economias mais avançadas 
para ampliar sua participação no comércio mundial. A principal limitação a uma inserção intemacional mais agressiva tem sido a permanência de fenômenos conjunturais, associados à instabilidade macroeconômica, que determinam a imposição de políticas restritivas ao crescimento dos investimentos, do produto e dos fluxos de comércio. A conquista de melhor posição no mercado internacional tem como pré-condição a consolidação de um ambiente macroeconômico estável, fundamental também para a maior competitividade das exportações brasileiras. $\dot{E}$ importante e estratégico o fato de ser a competitividade um fator interno, assim como é o destino das exportações, o que reforça a eficácia de uma política comercial ativa para o setor exportador. Esse último efeito, ainda que com importância relativa bem menor, apresentou comportamento crescente ao longo do período, indicando o direcionamento das vendas externas para mercados mais dinâmicos.

O efeito composição da pauta não foi, em nenhum periodo, favorável ao crescimento das exportações, apesar das mudanças estruturais ocorridas, que, pelo caráter localizado e específico em determinados sub-setores, revelaram-se de pequeno impacto global.

A expansão da capacidade tecnológica aparece como o caminho mais viável para a consolidação de vantagens comparativas já adquiridas em setores tradicionais, na sua ampliação em setores que sinalizam espaços potenciais e na exploração de novas vantagens comparativas em nichos de mais alta tecnologia.

Assim, o estímulo ao setor agroexportador não é só resultado direto do dinamismo do comércio internacional, mas também do esforço de desenvolvimento de estratégias que permitam conquistar maior participação nesse comércio.

Nesse sentido, além da pressuposta obtenção de um quadro de estabilidade macroeconômica que permita a atuação em ambiente de maior previsibilidade, é fundamental levar em conta a necessária reestruturação do setor produtivo nacional. Numa economia diversificada como a brasileira, em que não existe uma divisão rigorosa entre bens domésticos e exportáveis, já que estes são amplamente consumidos no mercado interno, há a possibilidade de direcionar a produção para atendimento do consumo doméstico, com orientação exportadora, 
de forma a aproveitar as oportunidades abertas para a maior integração do capital agroindustrial aos fluxos mundiais de mercadorias. 


\section{REFERÊNCIAS BIBLIOGRÁFICAS}

ALMEIDA, G. B Indicadores de competitividade para a indústria brasileira no período 1974/91. In: Perspectiva da economia brasileira . Rio de Janeiro, IPEA, 1993. Vol. 1, cap. 18, p 359 - 96.

BENEVENUTO, A. Agricultura de mercado interno versus agricultura de exportação: caracterização e tendências. In: CONGRESSO BRASILEIRO DE ECONOMIA E SOCIOLOGIA RURAL, 22, Piracicaba, SP, 24 a 28 de julho de 1989. Anais do XXI Congresso Brasileiro de Economia e Sociologia Rural. Piracicaba, 1989, p. $610-34$.

BRANCO, F. de C. et alii. $\mathrm{O}$ ambiente econômico internacional e suas perspectivas. In: Perspectiva da economia brasileira. Rio de Janeiro, IPEA, 1992. p. 177 - 206.

Brandão, A. S. P. \& Martin, W. J. Implications of agricultural trade liberalization for the developing countries. Agricultural Economics, Amsterdan, 8(1): 313-43, June 1993.

BROWN, H.J. Shift and share projections of regional economic growth: an empirical test. Joumal of Regional Science, 9: 1-17, 1969.

CARVALHO, J. L. Choques externos e a resposta interna: "Semeando vento e colhendo tempestade" na agricultura brasileira. Revista Brasileira de Economia, 43 (2): abr./jun. 1989. p. 139 - 75. 
DIAS, G.L.S. O papel da agricultura no processo de ajustamento. In: CONGRESSO BRASILEIRO DE ECONOMIA E SOCIOLOGIA RURAL, 27, Piracicaba, julho 1989. Anais do XXVII Congresso Brasileiro de Economia e Sociologia Rural. Piracicaba, 1989. p. 310 - 17. (Nota adicional).

DIAS, G.L.S. \& BARROS, J.R.M. Fundamentos para uma nova politica agricola, Coleção Análise e Pesquisa, 26: 39, novembro 1983.

FONTES, R.M.O. \& BARBOSA, M.L. Efeitos da integração econômica do Mercosul e da Europa na competitividade das exportações brasileiras de soja. Revista de Economia e Sociologia Rural, 29 (4): 335 - 51, out./nov./1991.

GOLDIN, I \& RESENDE, G.C. A agricultura brasileira na década de 80: crescimento numa economia em crise. Rio de Janeiro, IPEA, 1993. 119p. (Série IPEA, 138).

GONÇALVES, R. Competitividade internacional, vantagem comparativa e empresas multinacionais: o caso das exportações brasileiras de manufaturados. Pesquisa e Planejamento Econômico, 17 (2): 411 - 36, ago. 1987.

HOMEM DE MELO, F.B. A política econômica e o setor agricola no periodo pósguerra. Revista Brasileira de Economia, 33 (1): 25 - 63, jan./mar. 1979.

Análise das principais variáveis econômicas. In: A Agropecuária paulista, a liberalização comercial e o Mercosul. São Paulo, SEPLAU - SPIFIPE, 1993. p.3 - 35.

HORTA, M.H.T. Fontes de crescimento da exportações brasileiras na década de 70. Pesquisa e Planejamento Econômico, 13 (2): 507 - 42, ago. 1983.

HORTA, M.H.T.; WADDINGTON, S.; SOUZA, C. F. de, Fontes de crescimento das exportações brasileiras na década de 80. In: Perspectiva da economia brasileira. Rio de Janeiro, IPEA, 1993. Vol. 1, cap. 12, p. 231 - 46. 
IGLESIAS, R.M. A crise do comércio agrícola mundial. Fundação Centro de Estudos do Comércio Exterior ${ }_{1}$ maio 1990. (Texto para discussão interna, 31).

JANK, M.S. Mudanças no padrão de crescimento e dinâmica de ajuste externo do setor agroindustrial. In: CONGRESSO BRASILEIRO DE ECONOMIA E SOCIOLOGIA RURAL, 28, Florianópolis, julho 1990. Anais do XXVIII Congresso Brasileiro de Economia e Sociologia Rural. Florianópolis, 1990. p.297 - 307.

As safras agrícolas e o risco das importações de grãos. Preços Agrícolas, (93): 4-6, jul. 1994.

Mudanças no padrão de crescimento e dinâmica de ajuste externo do setor agroindustrial. In: CONGRESSO BRASILEIRO DE ECONOMIA E SOCIOLOGIA RURAL, 28, Florianópolis, julho 1990. Anais do XVIII Congresso Brasileiro de Economia e Sociologia Rural. Florianópolis, 1990. P.297 - 303.

JORGE, M. M. Estudo da competitividade da indústria brasileira. Campinas, MCT/FINEP/PADCT, 1993. (Nota técnica setorial do complexo "Papel e Gráfica Celulose).

JORGE, M. M. et alii. Estudo da competitividade da indústria brasileira. Campinas, MCT/FINEPIPADCT, 1993. (Nota técnica setorial do complexo Papel e Gráfica Papel)

KUME, H. A Liberalização das Importações de Produtos Agrícolas: A Experiência dos Anos 90. In: Teixeira, E. C. \& Aguiar, D.R.D, (ed.). Comércio Internacional e Comercialização Agrícola. Viçosa, UFV, Impr. Univ., 1995, cap. 8, p. 177 - 97.

LEAMER, E.E. \& STERN, R.M., Quantitative internacional economics. Allyn and Bacon, Boston, Massachusetts, Ch. 7. p.171-183, 1970. 
LOPES, M.R. As politicas macroeconômicas e o setor agrícola. In: SEMINÁRIO SOBRE PROBLEMAS E PERSPECTIVAS DA AGRICULTURA BRASILEIRA, Piracicaba, 1987. ESALQ/FEALQ, Piracicaba, São Paulo, p.66 - 78.

- $O$ poder das coalisões políticas de grupos de interesse de bloquear 0 desenvolvimento agricola. In: SEMINÁRIO DE DESENVOLVIMENTO AGRICOLA NA DÉCADA DE 90. Viçosa, MG, UFV, 1992. 27p.

LIFSCHITZ, J. A. Estudo da competitividade da indústria brasileira. Campinas, MCT/FINEPIPADCT. 1993. 66p (Competitividade da indústria de suco de frutas).

MAINON, D. et alii. Agricultura e ajustamento extemo: o papel das culturas de substituição de importação. In: CONGRESSO BRASILEIRO DE ECONOMIA E SOCIOLOGIA RURAL, 29, Campinas, agosto, 1991. Anais do XXIX Congresso Brasileiro de Economia e Sociologia Rural. Campinas, 1991, p. 60 - 82

MANOEL, A. \& BARROS, J.R.M. Agricultura brasileira: transformação e perspectiva na década de 80. Salvador. In: ENCONTRO NACIONAL DE ECONOMIA, 15, dezembro de 1987.

MEDEIRO, V.X. \& TEIXEIRA, E.C. Competitividade das exportaçōes de carnes bovina, suina e de frango do paises do Mercosul no mercado internacional. In: CONGRESSO BRASILEIRO DE ECONOMIA E SOCIOLOGIA RURAL, 32, Brasilia, julho 1994. Anais do XXXII Congresso Brasileiro de Economia e Sociologia Rural. Brasilia, 1994, p.545 - 63.

NONNEMBERG, M. J. B. et alii. O cenário econômico internacional e as perspectivas da economia brasileira. In: Perspectivas da economia brasileira. Rio de Janeiro, IPEA. 1994. V. 1, p. 173 - 96. 
OLIVEIRA, J. C. Incidência da taxação implícita sobre produtos agrícolas no Brasil: 1950/74. Pesquisa e Planejamento Econômico, 14 (2): 399 - 452, ago. 1984.

OLIVEIRA E SILVA, A. B. et alii. Retrospectiva da economia brasileira. In: Perspectivas da economia brasileira. Rio de Janeiro, IPEA, 1993, p. 13 - 41.

PAULA, N. de. O mercado intemacional e os desafios para a agricultura brasileira. Economia, (17): 39 - 48, 1993. CAACC

PFEIFER FILHO, A. Agricultura e o ajuste do setor extemo: Brasil - décadas de 70 e 80. Piracicaba, ESALQ/USP, 1990. 116p. (Tese MS).

PINHEIRO, A. C. \& ALMEIDA, G. B. Padrōes setoriais da proteção na economia brasileira. In: TEIXEIRA, E. C. \& AGUIAR, D.R.D. (ed.). Comércio Intemacional e Comercialização Agrícola. Viçosa, UFV, Impr. Univ., 1995, cap. 9, p. 199 - 239.

RESENDE, G.C. Ajuste extemo e agricultura no Brasil, 1981-86. Revista Brasileira de Economia, 42 (2): 101 - 37, abr/jun. 1988.

Política econômica e agricultura na década de oitenta. In: CONGRESSO BRASILEIRO DE ECONOMIA E SOCIOLOGIA RURAL, 27, Piracicaba, 1989. Anais do XXVII Congresso Brasileiro de Economia e Sociologia Rural, Piracicaba, 1989, p. 284 - 309.

RICHARDSON, J.D. Constant-Market-Shares analysis of export growth. Joumal of Intemational Economics, 1:227-39, 1971.

SANTANA, C. A. M. The impact of economic policies on the soybean sector of Brazil: an effective protection analyses. University de Minnesota, dezembro 1984. 291p. (Tese PhD.) 
SAYAD, J. Crédito rural no Brasil. São Paulo, FIPE/PIONEIRA, 1984. 125p.

SILVA, O.M. Elasticidade de substituição para o suco de laranja no mercado internacional. Revista de Economia e Śociologia Rural, 30, (2): 136 - 47, abr./jun. 1992.

STERN, R.M. Foreign trade and economic growth in Italy. New York, Frederic A. Praeger, New York, 1967. Ch. 2.

SZMRECSANYI, T. Pequena história da agricultura no Brasil. São Paulo, Contexto Editora, 1990. 120 p.

TYLER, W.C. Manufactured export and industrialization in Brazil. Tübingen, J. C.B. Mohr (Paul Siebeck), 1976.

VEIGA, P. M. Exportações brasileiras: desempenho, especialização intemacional e mudança estrutural. Rio de Janeiro, FUNCEX, junho 1991. 76 p. (Texto para discussão, 56).

ZINI, JR., A.A. As minidesvalorizações brasileiras: política adequada com choques de oferta? Estudos Econômicos, 18(1):51-91, jan./abr. 1989. 
APÊNDICE 1

CLASSIFICAÇÃO DOS PRODUTOS DA AGROINDÚSTRIA BRASILEIRA POR AGREGADO 


\section{PRODUTOS BÁSICOS}

- Açúcar demerara

- Algodão bruto

- Cacau cru

- Café (grão)

- Camarão congelado

- Carne bovina fresca/refrigerada/congelada

- Carne de frango congelada

- Castanha-de-caju

- Farelo de polpa cítrica

- Farelo de soja

- Fumo em folhas

- Peixe congelado

- Pimenta

- Soja (grão)

\section{PRODUTOS SEMIMANUFATURADOS}

- Açúcar cristal

- Madeira serrada

- Manteiga de cacau

- Óleo bruto de soja

- Liquor/pasta de cacau

- Pasta química de madeira

- Peles e couros

\section{PRODUTOS MANUFATURADOS}

- Açúcar refinado

- Café industrializado (solúvel)

- Carne bovina industrializada

- Fios de algodão

- Madeira ent/apl/plac/contraplacada

- Óleo refinado de soja

- Papel e suas manufaturas

- Suco de laranja concentrado/congelado

- Tecidos de algodão 
APÊNDICE 2

RELAÇÃO DOS COMPLEXOS AGROINDUSTRIAIS BRASILEIROS EXPORTADOS 
1. SOJA

- Farelo

- Grão

- Óleo bruto

- Óleo refinado

2. CAFÉ

- Grão

- Industrializado (solúvel)

\section{MADEIRA}

- Serrada

- Ent/apl/plac/contraplacada

- Pasta química

- Papel e suas manufaturas

4. LARANJA

- Suco concentrado

- Farelo de polpa

5. CARNE BOVINA

- Fresca/refrigerada/congelada

- Industrializada

- Peles e couros

6. CACAU

- Cru

- Manteiga

- Liquor/pasta

\section{AÇÚCAR}

- Demerara

- Cristal

- Refinado
8. FUMO

9. ALGODÃO

- Bruto

- Fios

- Tecidos

10. CASTANHA-DE-CAJU

12. FRANGO

13. PESCA

- Camarão congelado

- Peixe congelado 
APÊNDICE 3

SÉRIE DE DADOS DAS EXPORTAÇÕES DA AGROINDÚSTRIA BRASILEIRA DOS PRODUTOS BÁSICOS , SEMIMANUFATURADOS E MANUFATURADOS 

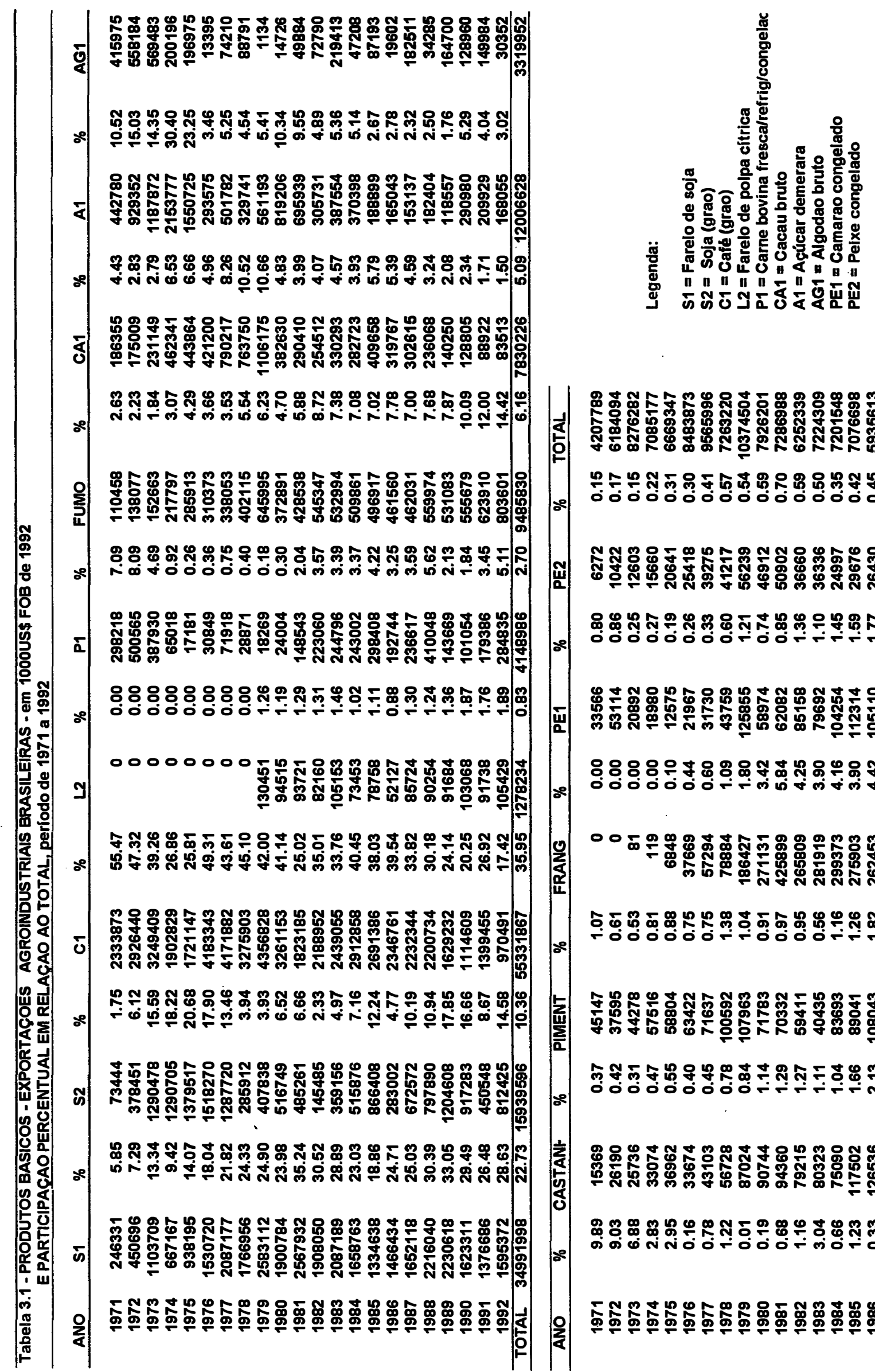

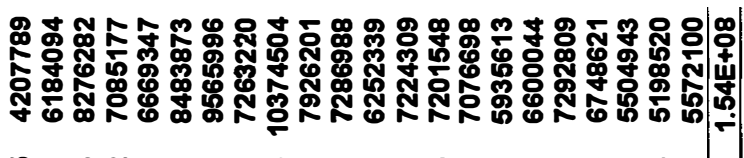

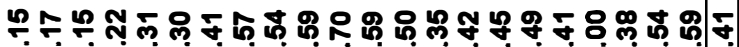
O00000000000000000000010

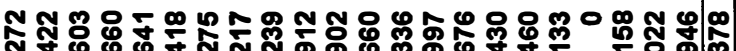

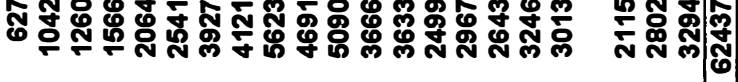

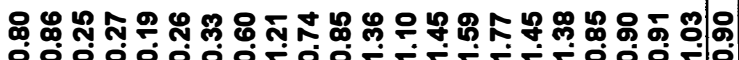

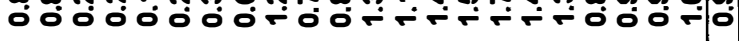

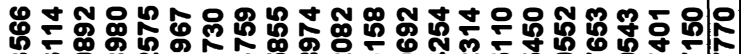

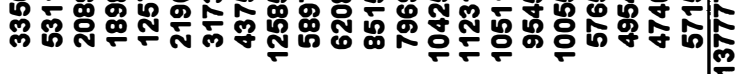

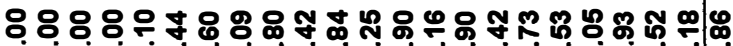

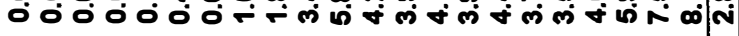

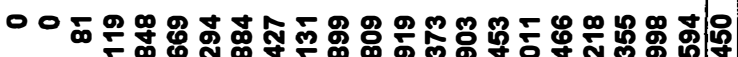

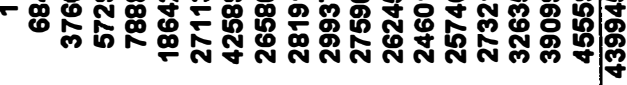

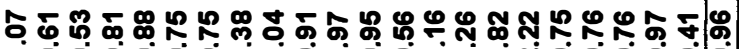

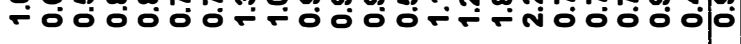

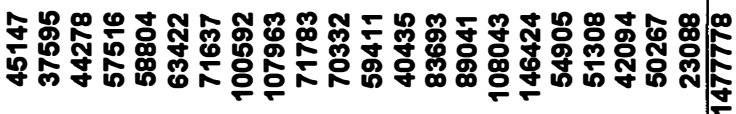

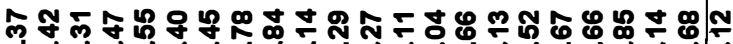

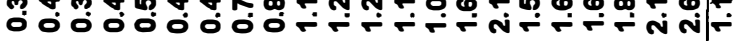

\&

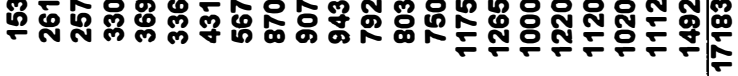

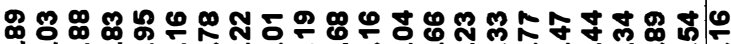

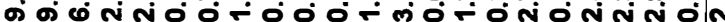

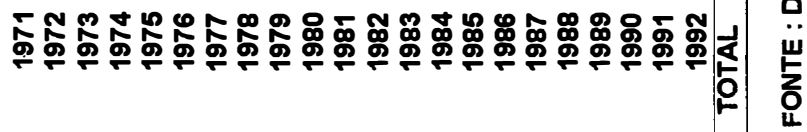




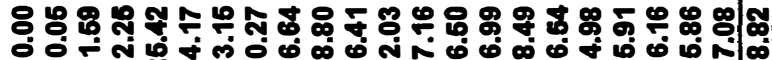

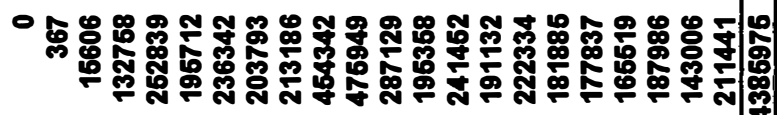

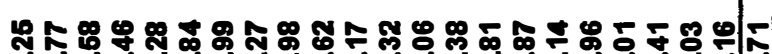

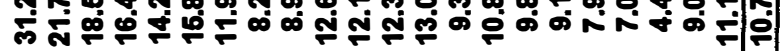

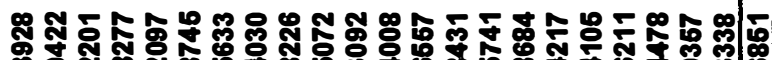

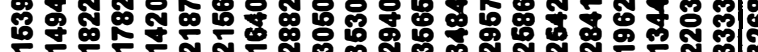

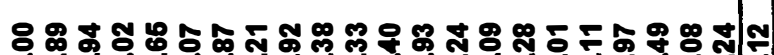

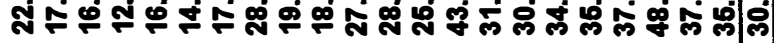

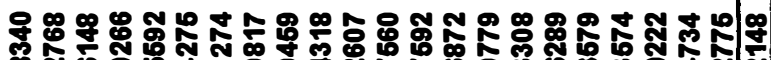

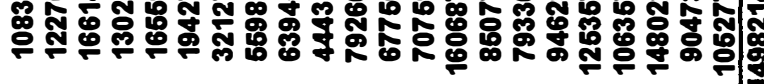

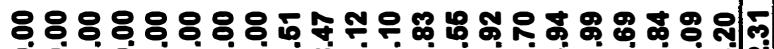

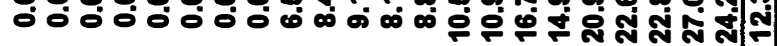

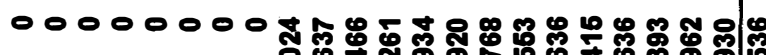

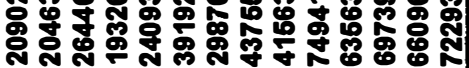

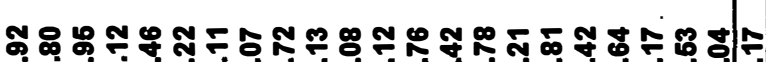

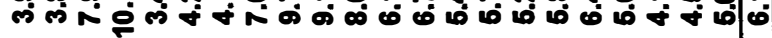

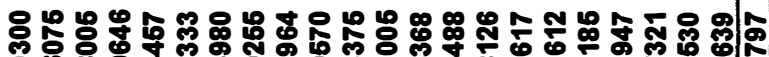

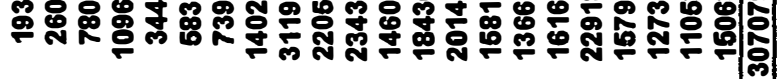

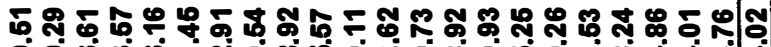

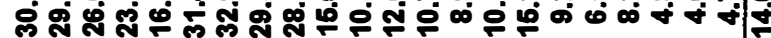

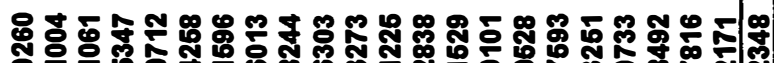

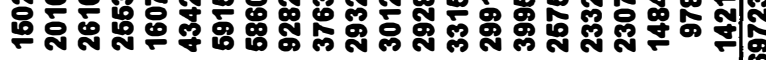

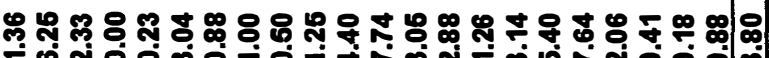

下

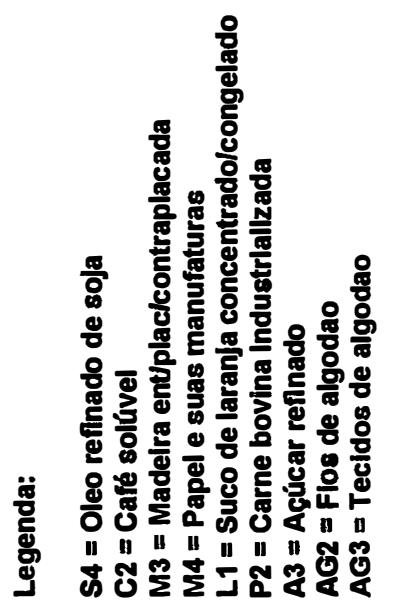

| ๑

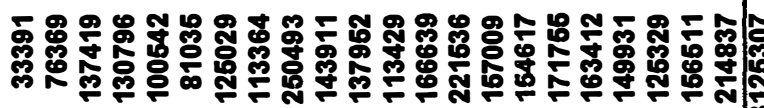

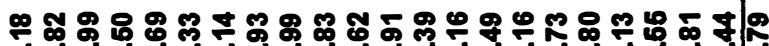

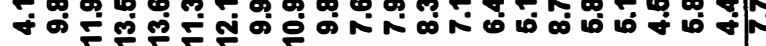

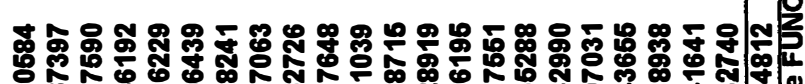

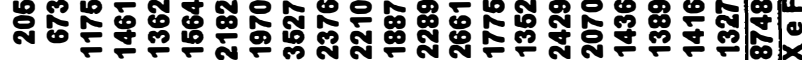

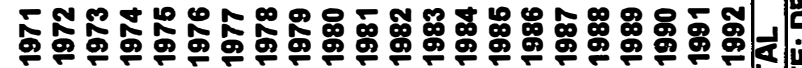




\section{APÊNDICE 4}

TAXAS GEOMÉTRICAS MÉDIAS DE CRESCIMENTO DAS EXPORTAÇÕES DA AGROINDÚSTRIA BRASILEIRA, POR PRODUTO 
Tabela 4.1 - Taxa Geométrica Média de Crescimento do Valor das Exportaçōes Brasllelras por Produto, em \%

\begin{tabular}{|c|c|c|c|c|c|c|}
\hline & PRODUTOS & Período Total & & & períodos & \\
\hline & & 1971/92 & $1971 / 81$ & $1982 / 92$ & $1982 / 87$ & $1988 / 92$ \\
\hline 1. Soja total & $\begin{array}{l}\text { farelo } \\
\text { grãos } \\
\text { oleo bruto } \\
\text { óleo refinado }\end{array}$ & 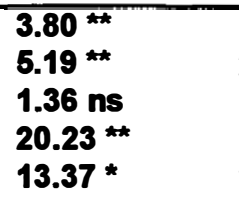 & 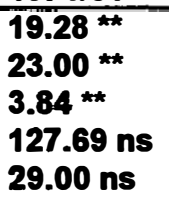 & 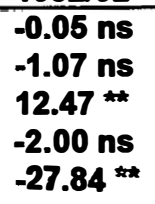 & $\begin{array}{l}-2.83 \mathrm{~ns} \\
-5.64^{\star} \\
23.75 * \star \\
-11.46 \mathrm{~ns} \\
-11.71 \mathrm{~ns}\end{array}$ & $\begin{array}{l}-9.94 \mathrm{~ns} \\
-10.77^{*} \\
-9.04^{* *} \\
34.29 \mathrm{~ns} \\
-51.59^{*}\end{array}$ \\
\hline 2. Café total & $\begin{array}{l}\text { grãos } \\
\text { solúvel }\end{array}$ & 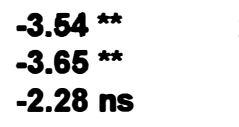 & $\begin{array}{l}2.88 \mathrm{~ns} \\
1.88 \mathrm{~ns} \\
1215 \text { ** }\end{array}$ & 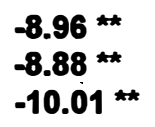 & $\begin{array}{l}-0.18 \mathrm{~ns} \\
-0.27 \mathrm{~ns} \\
0.13 \mathrm{~ns}\end{array}$ & 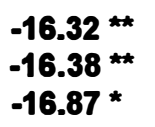 \\
\hline 3. Madeira total & $\begin{array}{l}\text { madeira serrada } \\
\text { madeira ent/pl/cont } \\
\text { pasta química } \\
\text { papel }\end{array}$ & $\begin{array}{l}10.77^{\star \star} \\
1.10^{\star \star} \\
7.22^{\star} \\
17.84^{\star \star} \\
12.18^{\star \star}\end{array}$ & $\begin{array}{l}13.58^{\star \star} \\
-5.39^{\star \star} \\
27.17^{\star} \\
34.33^{\star \star} \\
12.48 \mathrm{~ns}\end{array}$ & $\begin{array}{l}9.16 \text { ** } \\
12.80 \star \star \\
-2.47 \mathrm{~ns} \\
8.39 \star \star \\
13.99\end{array}$ & 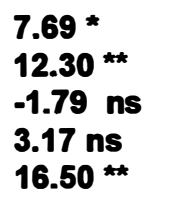 & $\begin{array}{l}-0.95 \mathrm{~ns} \\
5.69 \mathrm{~ns} \\
-11.27 \mathrm{~ns} \\
-0.15 \mathrm{~ns} \\
-0.32 \mathrm{~ns}\end{array}$ \\
\hline 4. Laranja total & $\begin{array}{l}\text { suco } \\
\text { farelo de polpa }\end{array}$ & $\begin{array}{l}13.44 \text { ** } \\
12.90 \text { ** } \\
-0.48 \text { ns }\end{array}$ & 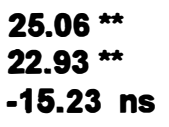 & $\begin{array}{l}3.36 \mathrm{~ns} \\
3.55 \mathrm{~ns} \\
2.36 \mathrm{~ns}\end{array}$ & $\begin{array}{l}3.06 \mathrm{~ns} \\
4.01 \mathrm{~ns} \\
-5.07 \mathrm{~ns}\end{array}$ & $\begin{array}{l}-4.32 \mathrm{~ns} \\
-4.98 \mathrm{~ns} \\
3.16 \mathrm{~ns}\end{array}$ \\
\hline 5. Carne bovina & $\begin{array}{l}\text { total } \\
\text { fresca/refrig./congelada } \\
\text { industrializada } \\
\text { peles e couros }\end{array}$ & $\begin{array}{l}2.96^{* *} \\
4.48^{* *} \\
2.14^{* *} \\
6.53^{* *}\end{array}$ & $\begin{array}{l}-0.03 \mathrm{~ns} \\
-20.32^{\star \star} \\
8.16^{\star \star} \\
11.18^{\star \star}\end{array}$ & $\begin{array}{l}0.94 \mathrm{~ns} \\
-3.00 \mathrm{~ns} \\
-4.33 \text { * } \\
11.57 \text { * }\end{array}$ & $\begin{array}{l}-1.36 \mathrm{~ns} \\
-0.61 \mathrm{~ns} \\
-5.15^{*} \\
4.15 \mathrm{~ns}\end{array}$ & $\begin{array}{l}0.22 \text { ns } \\
-4.94 \text { ns } \\
4.45 \text { ns } \\
1.70 \text { ns }\end{array}$ \\
\hline 6. Cacau total & $\begin{array}{l}\text { cru } \\
\text { manteiga } \\
\text { liquor/pasta }\end{array}$ & $\begin{array}{l}-2.01 \mathrm{~ns} \\
-4.91 \star \star \\
1.08 \mathrm{~ns} \\
5.30 *\end{array}$ & 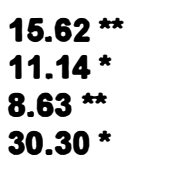 & $\begin{array}{l}-10.16 \text { ** } \\
-13.24 \text { ** } \\
-3.84 * \\
-4.39 *\end{array}$ & $\begin{array}{l}5.28 \mathrm{~ns} \\
3.30 \mathrm{~ns} \\
10.37 \star \star \\
1.90^{\star \star}\end{array}$ & $\begin{array}{l}-16.85 \star \star \\
-22.38 * \star \\
-6.98 \mathrm{~ns} \\
-25.30 *\end{array}$ \\
\hline 7. Açúcar total & $\begin{array}{l}\text { demerara } \\
\text { cristal } \\
\text { refinado }\end{array}$ & 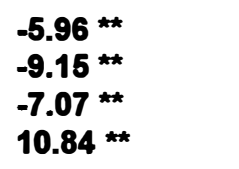 & $\begin{array}{l}15.00 * \\
-4.76 \mathrm{~ns} \\
-0.55 \mathrm{~ns} \\
72.56 \text { *k }\end{array}$ & $\begin{array}{l}-3.87 \text { * } \\
-6.16 \text { * } \\
1.99 \text { ns } \\
-3.60 \text { *t }\end{array}$ & $\begin{array}{l}12.03 * \star \\
-17.40 * \star \\
-8.58 \mathrm{~ns} \\
-5.86^{*}\end{array}$ & $\begin{array}{l}9.90 \mathrm{~ns} \\
4.16 \mathrm{~ns} \\
60.26 \text { ** } \\
2.01 \mathrm{~ns}\end{array}$ \\
\hline 8. Fumo & & $7.20^{\star \star *}$ & $16.15^{* *}$ & 2.90 ** & -3.60 ** & 9.23 * \\
\hline 9. Algodão total & $\begin{array}{l}\text { l } \\
\text { bruto } \\
\text { fios } \\
\text { tecidos }\end{array}$ & $\begin{array}{l}-1.08 \text { ns } \\
-4.79 \text { ns } \\
3.41 * \\
4.12^{\star \star}\end{array}$ & $\begin{array}{l}-3.84 \text { ns } \\
-34.41 \text { ** } \\
21.33^{\star \star} \\
10.87^{\star \star}\end{array}$ & $\begin{array}{l}1.54 \text { ns } \\
0.94 \text { ns } \\
-4.98 \text { ns } \\
1.09 \text { ns }\end{array}$ & $\begin{array}{l}0.08 \mathrm{~ns} \\
-5.65 \mathrm{~ns} \\
-2.03 \mathrm{~ns} \\
4.39 \mathrm{~ns}\end{array}$ & $\begin{array}{l}-1.58 \text { ns } \\
-3.31 \text { ns } \\
-8.63 \text { * } \\
6.07^{\star \star}\end{array}$ \\
\hline 10. Castanha & & 9.33 ** & 18.78 ** & 4.89 ** & 8.80 * & $4.03 \mathrm{~ns}$ \\
\hline 11. Pimenta & & -0.17 ns & 8.32 ** & -6.75 * & 23.97 * & -16.07 * \\
\hline 12. Frango & & $36.48^{\star \star}$ & 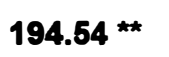 & 3.91 ** & -1.93 ns & $16.18^{\star \star}$ \\
\hline 13. Pesca total & $\begin{array}{l}\text { peixe congelado } \\
\text { camaräo congelado }\end{array}$ & $\begin{array}{l}4.45 \text { ** } \\
5.88 \text { ** } \\
4.12 \text { ** }\end{array}$ & $\begin{array}{l}14.49^{\star *} \\
10.99^{*} \\
23.87^{* *}\end{array}$ & 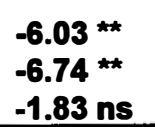 & $\begin{array}{l}2.06 \mathrm{~ns} \\
4.30 \mathrm{~ns} \\
-3.89 \mathrm{~ns}\end{array}$ & $\begin{array}{l}4.64 \text { ns } \\
-12.41 \text { ns } \\
2.19 \text { ns }\end{array}$ \\
\hline
\end{tabular}

FONTE: Cálculos do autor

* significativo a $5 \%$; * significativo de 5 a 15\%; e ns não-significativo 
APÊNDICE 5

RELAÇÃO DAS REGIÕES, DOS BLOCOS ECONÔMICOS E DOS PAISES CONSIDERADOS NA ANÁLISE 
MUNDO

\section{EUROPA}

UE

Alemanha
França
Reino Unido
Irlanda
Bélgica /Luxemburgo
Holanda
Itália
Espanha
Portugal
Grécia
Dinamarca
EFTA
Áustria
Suíça
Noruega
Suécia
Finlândia
Islândia
Estados Unidos
Canadá
México

AMÉRICA LATINA

MERCOSUL

Brasil

Argentina

Paraguai

Uruguai

ÁSIA

ORIENTE MÉDIO

“TIGRES ASIÁTICOS"

Coréia do Sul

Hong Kong

Cingapura

Japão

Tailândia

China

URSS

ÁFRICA

OCEANIA

Austrália 


\section{APÉNDICE 6}

RELAÇÃO DOS COMPLEXOS AGROINDUSTRIAIS EXPORTADOS NO MUNDO E DOS AGRUPAMENTOS DE PRODUTOS 


\section{COMPLEXOS AGROINDUSTRIAIS EXPORTADOS NO MUNDO}

\begin{tabular}{|c|c|c|c|}
\hline 1. Açúcar & $\begin{array}{l}\text { - bruto } \\
\text { - refinado }\end{array}$ & 12. Girassol & $\begin{array}{l}\text { - sement } \\
\text { - óleo } \\
\text { - torta }\end{array}$ \\
\hline 2. Carne & $\begin{array}{l}\text { - fresca } \\
\text { - preparada } \\
\text { - seca } \\
\text { - peles e couros }\end{array}$ & 13. Milho & $\begin{array}{l}\text { - grão } \\
\text { - óleo }\end{array}$ \\
\hline 3. Algodão & $\begin{array}{l}\text { - bruto } \\
\text { - semente } \\
\text { - óleo } \\
\text { - torta } \\
\text { - fios } \\
\text { - tecidos }\end{array}$ & 14. Arroz & \\
\hline 4. Cacau & $\begin{array}{l}\text { - grão } \\
\text { - pasta } \\
\text { - pó } \\
\text { - manteiga }\end{array}$ & 15. Trigo & \\
\hline
\end{tabular}

5. Fumo

16. Cevada

6. Pimenta

17. Centeio

7. Laranja - fruta

18. Aveia

8. Café

- grão

19. Outros cereais

- solúvel

9. Leite $\quad$ - fresco

- pó

- concentrado

20. Madeira - ent/plac/contraplacada

- pasta química

- papel

10. Soja

- grão

- óleo

21. Peixe

- fresco

- farelo

- refrig./congelado

11. Colza - grão

- óleo

- torta 


\section{AGRUPAMENTOS DE PRODUTOS:}

1. Grãos oleaginosos - Girassol semente

- Colza grão

- Soja grão

- Algodão semente

2. Óleos

- Algodão

- Soja

- Colza

- Girassol

- Milho

3. Farelos/Tortas - Algodão

- Soja

- Colza

- Girassol

4. Cereais

- Milho

- Arroz

- Trigo

- Cevada

- Centeio

- Aveia

- Outros cereais 


\section{APÊNDICE 7}

EXPORTAÇÕES E IMPORTAÇÕES TOTAIS BRASILEIRAS E SALDO DA BALANÇA COMERCIAL 
Tabela 7.1 - Exportações totais brasileiras, importações totais brasileiras e saldo da balança comercial, em milhões de dólares de 1992. Período 1982 - 92 (média móvel de 3 anos)

\begin{tabular}{llcc}
\hline ANOS & SALDO & EXPORTAÇÕES & IMPORTAÇÕES \\
\hline 1982 & -446 & 26037 & 26486 \\
1983 & 3297 & 25730 & 22436 \\
1984 & 7773 & 26808 & 19028 \\
1985 & 12195 & 28434 & 16238 \\
1986 & 12924 & 28653 & 15729 \\
1987 & 12210 & 28386 & 16176 \\
1988 & 14487 & 31014 & 16528 \\
1989 & 16858 & 34264 & 17407 \\
1990 & 16228 & 34859 & 18631 \\
1991 & 12768 & 33117 & 20341 \\
1992 & 12261 & 33105 & 20836 \\
\hline
\end{tabular}

Fonte: FGV.

Obs: Dados corrigidos pelo índice de preços no atacado dos Estados Unidos. 


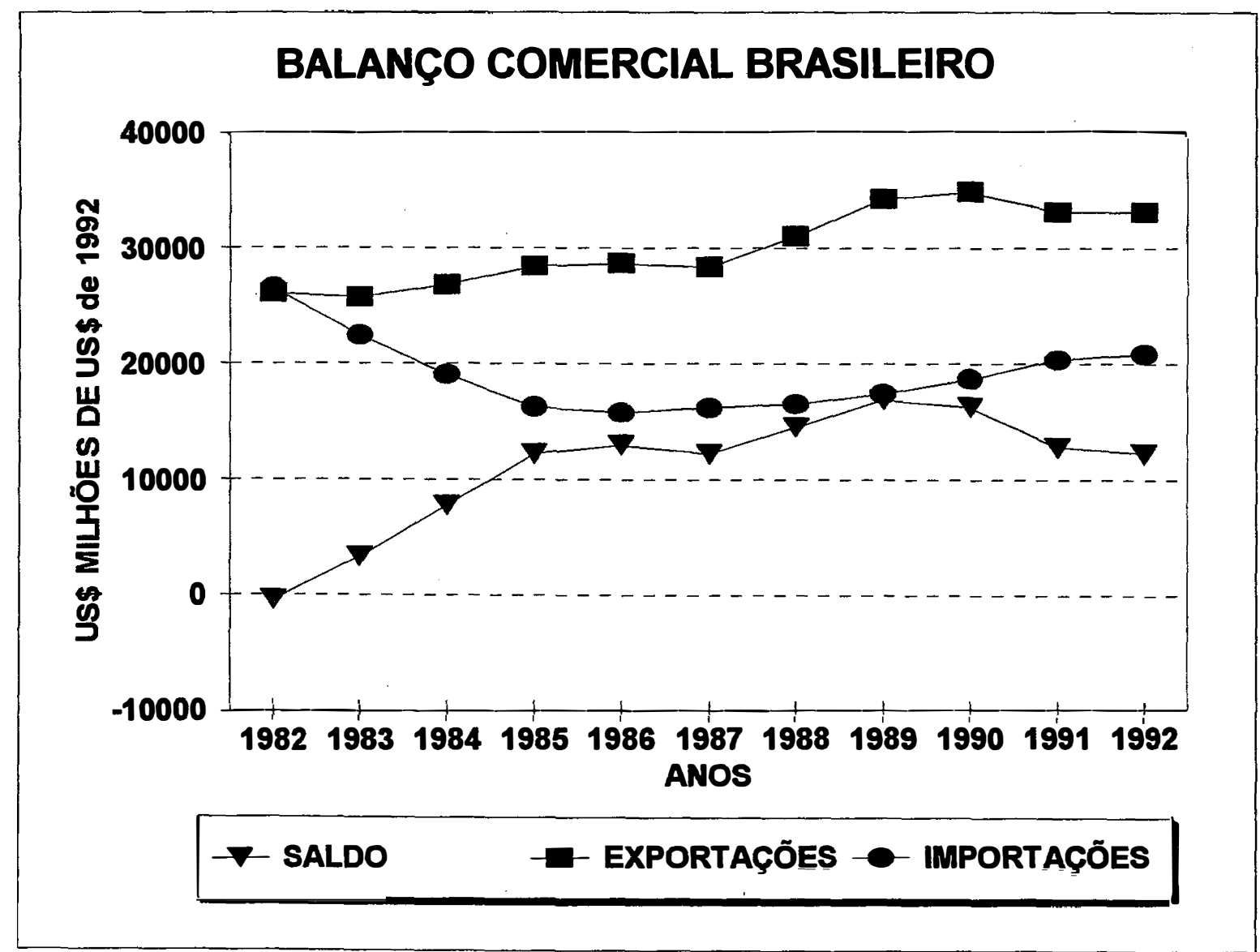

Figura 7.1 - Balanço comercial brasileiro, 1992 milhões de US\$ de 1992 